\title{
2. LATE PALEOCENE TO MIDDLE MIOCENE PLANKTONIC FORAMINIFER BIOSTRATIGRAPHY OF THE CEARA RISE ${ }^{1}$
}

\author{
Paul N. Pearson ${ }^{2}$ and William P. Chaisson ${ }^{3}$
}

\begin{abstract}
During Ocean Drilling Program Leg 154, five sites (Sites 925, 926, 927, 928, and 929) were drilled as a depth transect on the Ceara Rise in the western Atlantic Ocean. Each site consists mainly of pelagic carbonate sediments. Planktonic foraminifers are abundant throughout the sequences except in intervals of intense dissolution at the bathymetrically deeper sites. Faunas are typical of the low latitudes, and they are diverse and reasonably well preserved for much of the record. Recrystallization is mostly moderate, but it is severe at the greater burial depths.

A biostratigraphic framework is presented for the lower part of the stratigraphic interval, from Subzone P4c in the upper Paleocene to Zone N12 immediately below the most intensely dissolved level in the middle Miocene. This study replaces the previously published shipboard planktonic foraminifer biostratigraphy. It contains many additional datums and some revisions. Complete range charts of all the species recognized are also presented for the entire stratigraphic interval on the Ceara Rise.

Sedimentation on the plateau was almost continuous from the Paleocene to the Holocene. Although several small hiatuses are identified at individual sites, none extends across the whole plateau, so a remarkably complete geological history can be constructed. Much of this record is characterized by sedimentary cyclicity on Milankovitch time scales. This suggests that the Ceara Rise will be a key area for future advances in orbital-based chronology in which planktonic foraminifer biostratigraphy will be an important component.
\end{abstract}

\section{INTRODUCTION}

The Ceara Rise is an aseismic feature formed at the Mid-Atlantic Ridge in the Late Cretaceous. Its geological twin in the eastern equatorial Atlantic is the Sierra Leone Rise. Like its counterpart, the Ceara Rise now has a thick cover of pelagic sediment. One previous site, Deep Sea Drilling Project (DSDP) Site 354, was drilled on the Ceara Rise, and planktonic foraminifer results were given by Boersma (1977). Although the site was only spot-cored and was situated in relatively deep water $(4052 \mathrm{~m})$, biostratigraphic results indicated that Cretaceous to Holocene sediments exist there, and several unconformities punctuate the sequence, the most prominent of which is in the middle Miocene. An initial objective of Leg 154 drilling was to ascertain whether these unconformities are local or whether they extend across the Ceara Rise.

An exceptionally large amount of core $(5808 \mathrm{~m})$ was recovered during Leg 154, almost all of which is pelagic carbonate (ooze, chalk, or limestone with varying clay content). The initial shipboard biostratigraphic results were presented in the individual site chapters in Curry, Shackleton, Richter, et al. (1995). It was discovered in these investigations that the unconformities present at Site 354 are merely local features and do not extend across the rise.

The objectives of post-cruise planktonic foraminifer biostratigraphy are (1) to reconfirm all shipboard datum levels and, where necessary, introduce modifications; (2) to increase the sampling resolution for important datums and those intervals that were less well covered during shipboard work; (3) to identify additional datums that were not recognized on the ship; and (4) to present complete faunal lists and range charts of all species present, including those that are not zonal markers. These modifications are intended to improve the general biostratigraphic framework for the Leg 154 sites. In this pa-

'Shackleton, N.J., Curry, W.B., Richter, C., and Bralower, T.J. (Eds.), 1997. Proc. ODP, Sci. Results, 154: College Station, TX (Ocean Drilling Program).

${ }^{2}$ Department of Geology, Wills Memorial Building, Queens Road, Bristol, BS8 1RJ, United Kingdom. paul.pearson@bris.ac.uk

${ }^{3}$ Paleontological Research Institution, 1259 Trumansburg Road, Ithaca, New York 14850, U.S.A. (Present address: Institute of Marine Sciences, University of California, Santa Cruz, California 95064, U.S.A.) per, we present the results for the lower part of the sequence, from the upper Paleocene (Subzone P4c) to the lower part of the middle Miocene (specifically, the Zone N11/N12 boundary). Results for the higher part of the sequence are presented in Chaisson and Pearson (this volume).

Because all Leg 154 sites are situated in relatively close proximity (within $2^{\circ}$ of longitude and $3^{\circ}$ of latitude), we have avoided the repetitive task of making range charts for all sites. Instead, we present a general biostratigraphic framework for the Ceara Rise based on selected sites. To this end, we have made range charts for the late Eocene to middle Miocene of Hole 925A, and the late Paleocene to late Oligocene of Hole 929E. Taken together, these sequences span the entire time interval of interest and represent the best preserved (i.e., least dissolved and least recrystallized) parts of the record available from the region.

Because the Ceara Rise is in the low latitudes and relatively close to some of the classic land sections in which planktonic foraminifer biostratigraphy was developed, taxonomic assignment was generally straightforward. The Ceara Rise offers a remarkably complete stratigraphic record and will prove useful as a reference area for future correlations of low-latitude sequences, particularly with respect to calibrating foraminifer and nannofossil biostratigraphies. One extremely valuable feature of the record is that very long intervals are characterized by pronounced lithologic cycles that can be shown to result from the Milankovitch precession, obliquity, and eccentricity cycles (see other papers in this volume). The Ceara Rise will play a significant part in the development of orbital time scales in the middle Miocene to Holocene and probably also the Oligocene to lower Miocene. Thus, there will be great scope for further high-resolution sampling leading to the exact delineation of biostratigraphic datums relative to orbital cycles and the estimation of the lengths of intervals between datums based on cycle counts.

\section{METHODS}

The advanced hydraulic piston corer (APC), extended core barrel (XCB), and rotary coring system (RCS) were all used on various occasions to recover Leg 154 sediments. Many intervals were multiply cored, particularly those recovered by APC. 
In general, one sample per section was taken, enabling us to constrain datums to within approximately $1.5 \mathrm{~m}$. However, in the more recrystallized and less well-preserved intervals, the resolution was often less than $1.5 \mathrm{~m}$ because of lower sampling density and the occurrence of barren samples. Sediment volumes of $10 \mathrm{~cm}^{3}$ were taken, which generally yielded sufficient planktonic foraminifers for reliable age estimates, except at severely dissolved levels or when zonal marker species were very rare. In cores with strong lithologic banding, we generally sampled preferentially from the lighter, more carbonate-rich bands to obtain more numerous and less dissolved foraminifer tests. Obvious slumps, turbidites, and grain flows were avoided except when we desired an age for the reworked material. Unconsolidated oozes were washed in water. Chalky sediments were soaked in a mixture of detergent and peroxide solution to accelerate the disaggregation of the sediment before washing. More lithified samples were mechanically broken up using a chisel before being soaked and washed. All samples were washed over 150- and 40- $\mu \mathrm{m}$ sieves and dried on a hot plate at approximately $50^{\circ} \mathrm{C}$. Some samples were washed a second time when necessary.

In constructing the range charts, the following abundance categories were estimated for each species in a sample by visual estimation of the $>150-\mu \mathrm{m}$ size fraction: $\mathrm{A}=$ abundant $(>30 \%), \mathrm{C}=$ common $(15 \%-30 \%), \mathrm{F}=$ few $(3 \%-15 \%)$, and $\mathrm{R}=$ rare $(<3 \%)$. Note that small species recorded as "rare" may actually be abundant in the 40 - to 150 $\mu \mathrm{m}$ size fraction. In very poor assemblages of just a few specimens, all species with fewer than five specimens were marked as "rare." Preservation was assessed visually and, for some samples, by scanning electron microscope (SEM). Preservation in the samples used to construct the range charts was studied in random order to avoid "psychological drift" in the qualitative estimation of preservation indices.

Poor preservation was generally because of dissolution. The carbonate fraction is almost entirely removed by dissolution in some samples. In the more deeply buried parts of the sequence, particularly in the Paleocene and Eocene of Sites 925 and 929, recrystallization has also contributed to poor preservation (e.g., significant overgrowth and in-filling of sparry calcite was observed). The following qualitative scale was used to record dissolution, recrystallization, and fragmentation in the $>150-\mu \mathrm{m}$ size fraction: $1=$ light $(<20 \%$ fragments), $2=$ moderate $(20 \%-50 \%)$, and $3=$ severe $(50 \%-100 \%)$.

\section{BIOSTRATIGRAPHIC CORRELATION}

Standard Cenozoic geochronology and chronostratigraphy was in a state of flux during the period of gestation of this paper. At the time of drilling (January to March 1994), the time scale of Cande and Kent (1992) had already revealed several shortcomings in the geochronology of Berggren et al. (1985a, 1985b), which had been used so frequently on previous drilling legs. For this reason, and also because of recently available results from late Neogene astronomical calibration (Shackleton et al., 1990; Hilgen, 1991; and Leg 138 data later published by Shackleton et al., 1995), a "Leg 154 time scale" was developed (Curry, Shackleton, Richter, et al., 1995). All planktonic foraminifer datums used in this study were transferred to the Leg 154 time scale before drilling, which for the time interval of interest in this paper equates to the time scale of Cande and Kent (1992). The estimated positions of datums with respect to magnetic polarity reversals are based on previous stratigraphic compilations (Berggren et al., 1985a, 1985b; Chaisson and Leckie, 1993; see Curry, Shackleton, Richter, et al., 1995). These age assignments are given in the first column of Table 1 . They were used in the shipboard study and in the present paper, even though it has become clear from our studies that some datums do not correlate from site to site on the Ceara Rise at precisely the expected level (i.e., by comparison to other biostratigraphic datums on the Leg 154 time scale). The original age estimates have to be retained to avoid circular arguments in generating age models for the Leg 154 sites, especially in the absence of magneto- stratigraphy. We hope that the results presented here will permit future recalibration of some datums, particularly as orbital calibration improves, but that is outside the scope of the present paper.

During drilling we found eight additional datums in the time interval of interest that were not originally listed on the Leg 154 time scale, but that were found to correlate well in the region. These datums were not used in the generation of age models for Leg 154 sites, but their positions were recorded at every site they were encountered. In the datum tables for the various sites that follow (Tables 2, 4, 5, 6, and 7), their ages are not listed. However, we have made post-drilling estimates for the positions of these datums on the Leg 154 time scale by interpolation between other planktonic foraminifer and nannofossil datums. These are shown in the second column of Table 1 . We hope that these datums will also be found useful for future biostratigraphic correlation in the region.

When this paper was in review, the revised geochronology and chronostratigraphy of Berggren et al. (1995) became available. Like the Leg 154 time scale, that work is also based partly on the time scale of Cande and Kent (1992), but with modifications made by Cande and Kent (1995). Berggren et al. (1995) have reassessed many of the important Cenozoic datums and have made some significant alterations to the lists given by Berggren et al. (1985a, 1985b) and Berggren and Miller (1988). Each datum used in this paper is discussed individually below, including references to the new comments in Berggren et al. (1995) where necessary.

The Neogene tropical zonation scheme that we used is based on the work of Blow (1969), with certain modifications (discussed below). For the Paleogene, we used the zonation of Berggren and Miller (1988), including several important modifications suggested by W.A. Berggren (pers. comm., 1994), in advance of the revised geochronology and chronostratigraphy published by Berggren et al. (1995). Figure 1 shows the biostratigraphy we adopted on Leg 154, which followed the latest available information at the time of drilling, in comparison with other commonly used zonations. In retrospect, we recognize that it is an unfortunate mixture of the "old" and "new" nomenclatures, but we retain it here to avoid potential confusion for those comparing the Initial Reports and Scientific Results volumes for the leg. Note that we follow the revised zonal nomenclature of Berggren et al. (1995) for most of the Paleogene (except for the base of Zone P16), but not for the Neogene.

Partly because of the problems of zonal nomenclature, our method of presenting the biostratigraphic framework differs from our previous contributions by focusing on datums rather than biozones. In addition, we have adopted a terminology for the "base" and "top" of stratigraphic ranges for consistency with the nannofossil biostratigraphy (rather than "first occurrence" and "last occurrence").

In standard planktonic foraminifer biostratigraphy (e.g., Berggren et al., 1995), datums are considered as instantaneous "events," at least for individual localities. This view is theoretically justified not only for extinctions and saltations, but also for gradual transitions between morphospecies in evolving lineages. However, there is an inevitable problem with gradual transitions in that different workers are likely to place the thresholds between morphospecies in subtly different places. This imparts an uncertainty to all those datums that are not obviously extinction or speciation events in the biological sense. In planktonic foraminifer biostratigraphy, the majority of important datums (including both "base" and "top" datums) are probably of this type, and it should be admitted that they are therefore not amenable to high-resolution analysis unless strict species definitions are employed. At present, all workers decide for themselves exactly which criteria are best used to make the necessary fine distinction between ancestral and descendent forms. Consequently, we contend that for many of the zones used, uncertainties in taxonomic assignment are at least as important a problem for correlation as are diachroneity and uncertainties in age assignment. We have attempted to classify each of our datums into one of four categories based on our observations regarding the extent of morphological isolation of the morphospecies 
Table 1. Comparison of the age assignments of planktonic foraminifer datums used in this study and in Berggren et al. (1995).

\begin{tabular}{|c|c|c|c|}
\hline Planktonic foraminifer datums & $\begin{array}{c}\text { Curry, } \\
\text { Shackleton, } \\
\text { Richter, et al. } \\
\text { (1995) }\end{array}$ & $\begin{array}{c}\text { New datum } \\
\text { estimates } \\
\text { (post-drilling) }\end{array}$ & $\begin{array}{l}\text { Berggren } \\
\text { et al. (1995) }\end{array}$ \\
\hline Base Fohsella fohsi & 13.5 & \multirow{7}{*}{14.2} & 12.7 \\
\hline Base Fohsella "praefohsi" & 14.0 & & 12.7 \\
\hline Top Clavatorella bermudezi & - & & - \\
\hline Top Globorotalia archeomenardii & 14.2 & & - \\
\hline Top Fohsella peripheroronda & 14.6 & & 14.8 \\
\hline Base Fohsella peripheroacuta & 14.7 & & 14.8 \\
\hline Top Praeorbulina sicana & 14.8 & & 14.8 \\
\hline Base Globorotalia praemenardii & 14.9 & \multirow{3}{*}{15.0} & - \\
\hline Top Globigerinatella insueta & - & & - \\
\hline Base Orbulina universa (=suturalis) & 15.1 & & 15.1 \\
\hline Base Clavatorella bermudezi & - & \multirow[t]{6}{*}{15.8} & - \\
\hline Base Globorotalia archeomenardii & 15.5 & & - \\
\hline Base Praeorbulina circularis & 16.0 & & 16.0 \\
\hline Base Praeorbulina glomerosa & 16.1 & & 16.1 \\
\hline Base Praeorbulina sicana & 16.4 & & 16.4 \\
\hline Top Catapsydrax dissimilis & 17.3 & & 17.3 \\
\hline Base Globigerinatella insueta s.str. & - & \multirow[t]{2}{*}{17.4} & - \\
\hline Top Globoquadrina binaiensis & 19.1 & & - \\
\hline Base Globigerinatella sp. & - & \multirow[t]{3}{*}{20.2} & - \\
\hline Top Paragloborotalia kugleri & 21.6 & & 21.5 \\
\hline Top Paragloborotalia pseudokugleri & 23.3 & & - \\
\hline Base Globoquadrina dehiscens & - & - & 23.2 \\
\hline Top "Globigerina" ciperoensis & - & 23.3 & - \\
\hline Base Globigerinoides trilobus s.l. & - & 23.4 & - \\
\hline Base Paragloborotalia kugleri & 23.7 & & 23.8 \\
\hline Top "Globigerina" angulisuturalis & 23.3 & & 21.6 \\
\hline Base Paragloborotalia pseudokugleri & 26.3 & & 25.9 \\
\hline Top Paragloborotalia opima & 27.1 & & 27.1 \\
\hline Top Chiloguembelina cubensis & 28.5 & & 28.5 \\
\hline Base "Globigerina" angulisuturalis & 29.7 & & 29.4 \\
\hline Top Turborotalia ampliapertura & 30.3 & & 30.3 \\
\hline Top Pseudohastigerina naguewichiensis & 32.5 & & 32.0 \\
\hline Top Hantkenina alabamesis & 33.75 & & 33.7 \\
\hline Top Turborotalia cerroazulensis & 33.9 & & 33.8 \\
\hline Top Cribrohantkenina inflata & 34.0 & \multirow{13}{*}{34.0} & 34.0 \\
\hline Top Clavigerinella eocanica & - & & - \\
\hline Base Turborotalia cuialensis & 35.1 & & 35.2 \\
\hline Top Turborotalia pomeroli & 35.2 & & 35.3 \\
\hline Base Cribrohantkenina inflata & 35.4 & & 35.4 \\
\hline Base Globigerinatheka semiinvoluta & 38.8 & & 38.4 \\
\hline Top Morozovella spinulosa & 38.1 & & 38.1 \\
\hline Top Orbulinoides beckmanni & 40.2 & & 40.1 \\
\hline Base Orbulinoides beckmanni & 40.6 & & 40.5 \\
\hline Top Morozovella aragonensis & 43.7 & & 43.6 \\
\hline Base Morozovella aragonensis & 52.0 & & 52.3 \\
\hline Top Morozovella velascoensis & 53.4 & & 52.3 \\
\hline Top Globanomalina pseudomenardii & 56.1 & & 55.9 \\
\hline
\end{tabular}

Notes: See text for discussion. $-=$ no age assignment given

in question, or its intergradation with other forms. The four categories of biostratigraphic datum are as follows:

1. Extinction (example: top of Hantkenina alabamensis). An extinction corresponds to the final and unambiguous termination of a morphological lineage in a stratigraphic section. We would expect all workers to agree on the level of such an event at a site given the same observations. Of course, the extinction may be diachronous between sites if, for example, the geographic range of the species contracted to a particular area before its extinction. The local disappearance of a lineage, followed by its reappearance, is a special case of such an "extinction." The final genetic extinction of a lineage refers to its global last occurrence and cannot be determined from one small area.

2. Pseudoextinction (example: top of Paragloborotalia pseudokugleri). A pseudoextinction occurs when a morphospecies disappears from the record but intergrades with a descendant form in an apparently unbroken lineage. Such a datum might be placed with equal validity at different stratigraphic levels by different workers given the same observations, because it depends on a subjective judgement as to which morphologically intermediate foraminifers are most similar to the type specimens of the ancestral and descendent taxa. In such cases, it is particularly necessary to carefully de- scribe the criteria used to separate the two taxa, as this is an integral part of the definition of the datum (in this paper, these distinctions are described in the "Systematic Taxonomy" section below). It is worth bearing in mind that many gradual transitions can, in principle, be defined unambiguously if common agreement can be reached. For example, the top of Morozovella lensiformis might refer to the uppermost occurrence of individuals in the $M$. lensiformis-Morozovella aragonensis chronocline that possess fewer than five whole chambers in the final whorl. However, many pseudoextinctions involve multiple characters and are therefore difficult to pinpoint exactly. As is the case for true extinctions, there is no reason why pseudoextinctions should be synchronous between areas, because they depend on a combination of genetic and environmental influences.

3. Dispersal (possible example: base of Clavatorella bermudezi). If a species arises suddenly in a saltational event and then spreads rapidly, it may provide an unambiguous datum level. However, this eventuality seems to be rare among the planktonic foraminifers, which tend to evolve by gradual transitions.

4. Pseudospeciation (example: base of Paragloborotalia kugleri). Just as morphospecies may disappear from the record by gradual anagenetic evolution ("pseudoextinction," see above), so they may appear in the record by gradual transition 


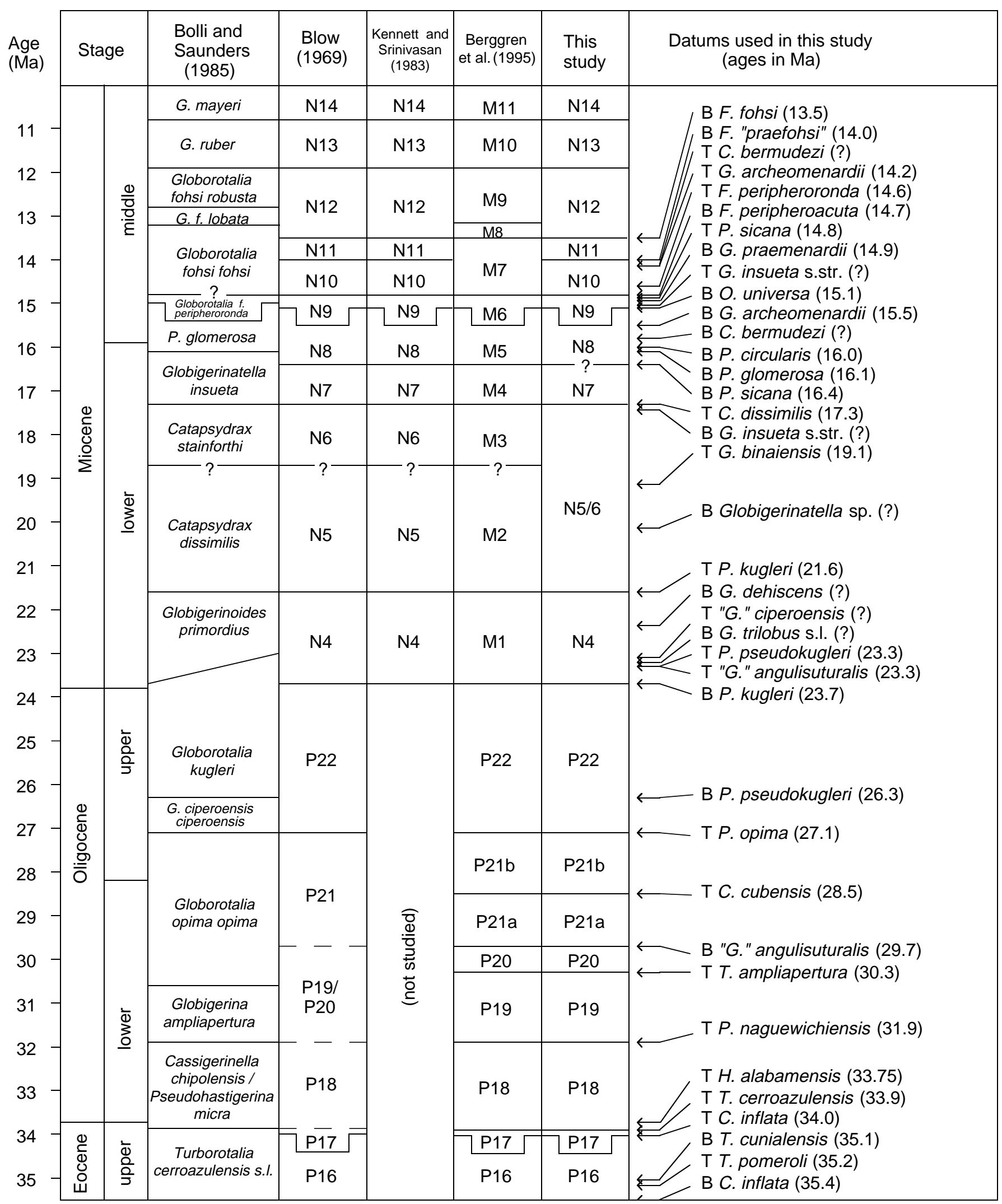

Figure 1. Planktonic foraminifer biostratigraphic zonation used in this study in comparison to other widely used schemes. The positions of all the datums identified in this study are shown. The age estimates given are those estimated before drilling. 


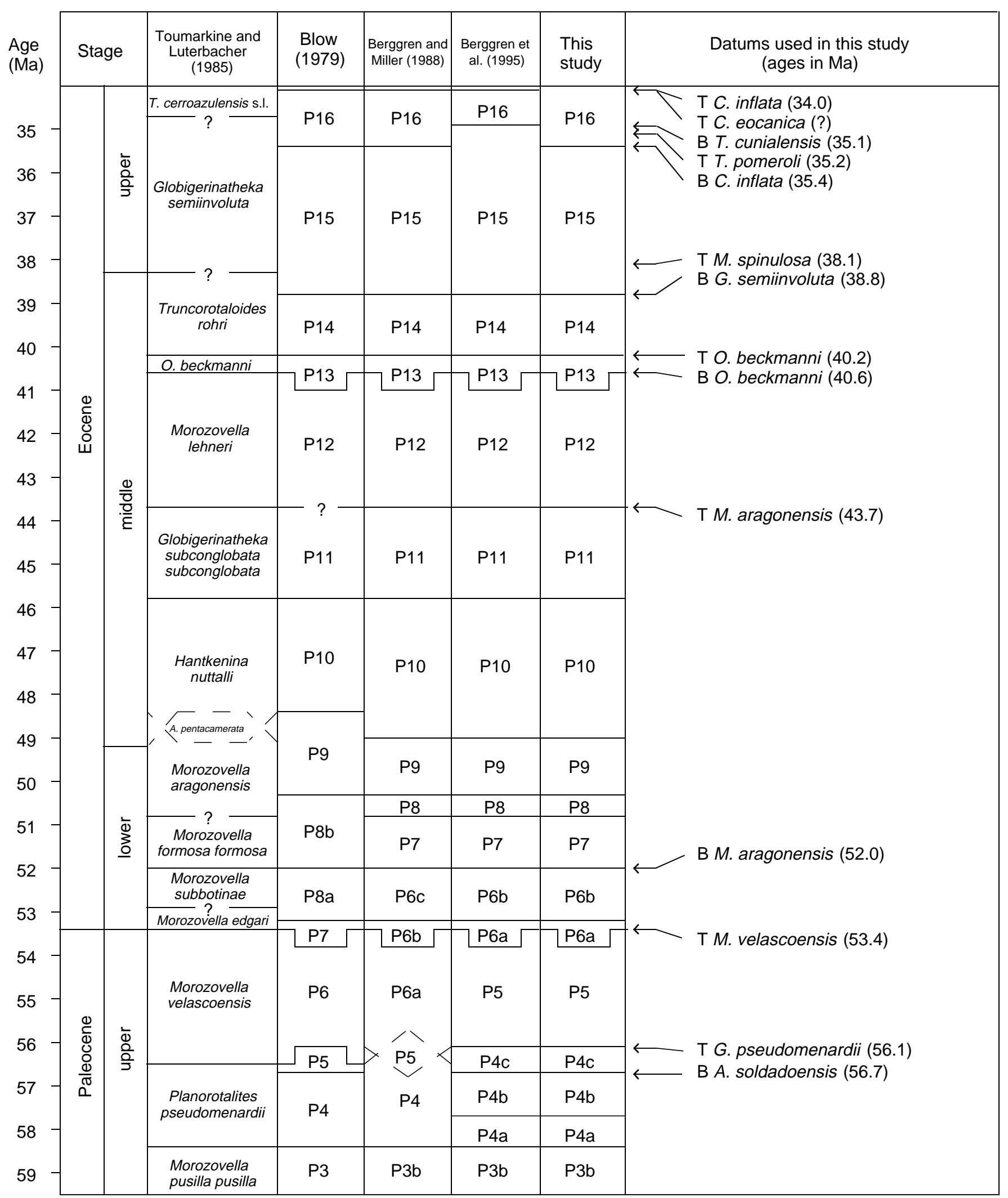

Figure 1 (continued). 
(Pearson, 1992, 1993). Such datums present the same problems of ambiguity as discussed above under pseudoextinction. As in that case, it is necessary to carefully describe the method of distinction between morphospecies because that is an integral part of the definition of the datum.

A total of 47 datums were used in the planktonic foraminifer biostratigraphy of the N4 through N12 interval in this study. In the list below, each datum is reviewed with respect to (1) its ease of recognition, particularly with respect to possible ambiguities in the placement of taxonomic boundaries between species; and (2) its level in the region.

\section{Base Fohsella fohsi (13.5 Ma; Base Zone N12/Top Zone N11)}

Category: Pseudospeciation. Norris et al. (1993) argued that the first appearance of Fohsella fohsi was a biological speciation event on the basis of an inferred habitat shift in the lineage at the time the first "keeled" individuals occurred. Despite this, there is no evidence of a cladogenetic event at that time. Fohsella fohsi appears to arise by anagenetic transition from Fohsella "praefohsi" (although see comments below regarding the latter species).

Correlation: The age for this datum given in Berggren et al. (1995) is substantially younger that given in Berggren et al. (1985b) due to a reinterpretation of the magnetostratigraphy at DSDP Site 563 (Wright and Miller, 1992). However, the datum was found at approximately the originally expected level at Site 925 . This stratigraphic level is within a severely dissolved interval in the deeper Ceara Rise sites.

\section{Base Fohsella "praefohsi" (14.0 Ma; Base Zone N11/Top Zone N10)}

Category: Pseudospeciation. Fohsella "praefohsi" arises by gradual transition from Fohsella peripheroacuta. The two morphospecies are commonly found together as part of the same variable population above the base of $F$. "praefohsi." Reference is made to the "Systematic Taxonomy" section below for a discussion of the controversy surrounding the species $F$. "praefohsi" and its distinction from $F$. peripheroacuta.

Correlation: The datum was found in Holes 925A and 926A and occurs at the expected level below the top of the nannofossil Sphenolithus heteromorphus. Note that Berggren et al. (1995) follow Bolli and Saunders (1985) by rejecting Blow and Banner's (1966) original concept of praefohsi as an intermediate between peripheroacuta and fohsi, and have therefore revised their zonation accordingly (see Fig. 1).

\section{Top Clavatorella bermudezi (estimate for Ceara Rise: $14.2 \mathrm{Ma}$ )}

Category: Extinction. Although Clavatorella bermudezi is always rare, it can easily be spotted by scanning large samples at low magnification. It is found in almost every sample within its limited stratigraphic range. Therefore, its local disappearance seems to have been a "real" event rather than an artifact of its rarity.

Correlation: The extinction appears to be highly diachronous on a global basis but works well across the Ceara Rise. In Holes 925A and 926A, the top of $C$. bermudezi was recorded close to the top of Fohsella peripheroronda.

\section{Top Globorotalia archeomenardii (14.2 Ma)}

Category: Extinction. Globorotalia archeomenardii appears to be separate and distinct from Globorotalia praemenardii at the top of its range, but detailed morphometric studies would be necessary to establish it.
Correlation: Although taxonomic differentiation of the two forms is subtle, the extinction of $G$. archeomenardii appears to be a reliable datum below the base of Fohsella "praefohsi."

\section{Top Fohsella peripheroronda (original estimate: $14.6 \mathrm{Ma}$; revised estimate for Ceara Rise: $14.2 \mathrm{Ma}$ )}

Category: Pseudoextinction. This datum is part of the gradual evolution in the Fohsella lineage. Fohsella peripheroronda is a morphotype with a more rounded periphery than Fohsella peripheroacu$t a$, but both can be found in the same intergrading populations. The level of the datum therefore depends largely on taxonomic criteria, a problem accentuated by the great difference in morphology between the respective holotypes (Blow and Banner, 1966; see the "Systematic Taxonomy" section for a discussion of these two species).

Correlation: Rare Fohsella peripheroronda was found among the dominantly $F$. peripheroacuta populations up to a short interval below the base of $F$. "praefohsi." This datum depends on such fine distinctions that we feel extensive morphometrical studies would be necessary to establish it reliably.

\section{Base Fohsella peripheroacuta (14.7 Ma; Base Zone N10/Top Zone N9)}

Category: Pseudospeciation. This datum is another transitional stage in the evolution of the Fohsella lineage and is difficult to apply at a high resolution without morphometric analysis (see comments above).

Correlation: The datum was found at approximately the expected level at Site 926. At Site 925, it was higher than expected and may indicate a minor unconformity or condensed interval there.

\section{Top Praeorbulina sicana (14.8 Ma)}

Category: Pseudoextinction. In Leg 154 material, all of the intergrading Praeorbulina morphospecies coexist for an interval alongside Orbulina to approximately the same level, below the base of $F$. peripheroacuta.

Correlation: The datum occurs slightly lower in Hole 925A than was found in Holes 925B, 926A, or 926B, probably a result of the rarity of specimens.

\section{Base Globorotalia praemenardii (14.9 Ma)}

Category: Pseudospeciation. Globorotalia praemenardii seems to have evolved from Globorotalia archeomenardii by gradual transition, although the two forms may be morphologically isolated at higher levels before the extinction of $G$. archeomenardii.

Correlation: In Holes 925B, 926A and 926B, the level could not be distinguished from the top of Praeorbulina sicana.

\section{Top Globigerinatella insueta (estimate for Ceara Rise: 15.0 Ma)}

Category: Extinction. Globigerinatella insueta disappeared from the record without leaving any direct descendents.

Correlation: On the Ceara Rise, this event occurs in the lower part of Zone N9 a little below the base of Globorotalia praemenardii. Higher occurrences in certain Pacific sites (Pearson, 1995) may be because of reworking there, or may indicate marked diachrony in the datum.

\section{Base Orbulina universa (5.1 Ma; Base Zone N9/Top Zone N8)}

Category: Pseudospeciation. Orbulina evolved by gradual transition from Praeorbulina circularis.

Correlation: At Sites 925 and 926, the Orbulina datum is above the top of the nannofossil Helicosphaera ampliaperta as expected. 
The shorter stratigraphic interval between these datums at Site 926 may point to a minor unconformity there.

\section{Base Clavatorella bermudezi (estimate for Ceara Rise: 15.8 Ma)}

Category: Dispersal? Clavatorella bermudezi evolved from Globorotaloides hexagonus, apparently by rapid transition. However, the latter species is not present in Ceara Rise sediments.

Correlation: The base of Clavatorella on the Ceara Rise is in the higher part of Zone N8 between the top of the nannofossil Helicosphaera ampliaperta and the base of Orbulina. This compares well with the stratigraphic range given by Kennett and Srinivasan (1983) and the level recorded in the West Pacific (Pearson, 1995) where Globorotaloides hexagonus is present.

\section{Base Globorotalia archeomenardii (original estimate: 15.5 Ma; revised estimate for Ceara Rise: $16.2 \mathrm{Ma}$ )}

Category: Pseudospeciation? Globorotalia archeomenardii probably evolved from Globorotalia praescitula.

Correlation: This datum was found lower than expected in comparison with the Pacific records of Sites 806 (Chaisson and Leckie, 1993) and 872 (Pearson, 1995). In Sites 925 and 926, it was found at or slightly below the base of Praeorbulina glomerosa. The higher level in Site 929 is probably the result of dissolution.

\section{Base Praeorbulina circularis (16.0 Ma)}

Category: Pseudospeciation. This is the penultimate stage in the anagenetic transition of Globigerinoides into Orbulina.

Correlation: The level of this datum is variable from site to site because of the rarity of the species and the effects of dissolution. However, in Hole 926B, Praeorbulina circularis was found below the top of the nannofossil Helicosphaera ampliaperta as expected.

\section{Base Praeorbulina glomerosa (16.1 Ma)}

Category: Pseudospeciation.

Correlation: Praeorbulina glomerosa is more common in Ceara Rise sediments than Praeorbulina circularis. Consequently, the datum was found at a much more consistent level.

\section{Base Praeorbulina sicana (16.4 Ma; base Zone N8/top Zone N7)}

Category: Pseudospeciation. Praeorbulina sicana evolved from its ancestor, Globigerinoides bisphericus, by the acquisition of a fourth aperture around the base of the final chamber and a more spherical shape. This distinction was ascertained by Jenkins et al. (1981) from a reexamination of the respective holotypes.

Correlation: Although there is an element of doubt about the calibration of this datum because of uncertainty over the correct species concept, it appears to correlate well on the Ceara Rise at about 16.4 Ma. Differing species concepts within the Globigeronoides-Praeorbulina lineage mean that Zone N8 must be defined with particular care. The problem lies in the distinction between Globigerinoides bisphericus and Praeorbulina sicana. In the zonal schemes of Blow (1969) and Kennett and Srinivasan (1983), the two species were treated as synonyms, and the base of Zone N8 was drawn at the first occurrence of "Globigerinoides sicanus" (= G. bisphericus). According to Jenkins et al. (1981), P. sicana has four apertures around the final chamber instead of three as in G. bisphericus. Accepting this view, the base of Zone N8 might be drawn at the base of either species (or indeed a third species such as Praeorbulina curva, as suggested by Jenkins et al., 1981). Studies of well-preserved Pacific material (Chaisson and Leckie, 1993; Pearson, 1995) suggest that G. bisphericus appears quite low in the record and $P$. curva is often rather scarce. Consequently, we believe that the base of $P$. sicana is the best candidate for global correlation and is used to mark the base of Zone N8 in this study (see also Melillo, 1988; Chaisson and Leckie, 1993; Pearson, 1995; also Berggren et al., 1995, wherein "Zone M5" = Zone N8). An element of doubt remains, however, regarding the operational distinction between the two species in poorly preserved material (see taxonomic discussion of $P$. sicana).

\section{Top Catapsydrax dissimilis (17.3 Ma; base Zone N7/top Zone} N5/6)

Category: Extinction. Catapsydrax dissimilis disappeared from the record leaving no direct descendents.

Correlation: Although never common, Catapsydrax dissimilis is present in sufficient numbers in this region to provide a reliable datum above the base of the nannofossil Sphenolithus heteromorphus.

\section{Base Globigeriantella insueta s. str. (estimate for Ceara Rise: 17.4 Ma)}

Category: Pseudospeciation. The evolution of Globigerinatella is a gradual transition from Globigerinita glutinata s.l. as described by Pearson (1995) from material in the western Pacific. A similar transition was observed in this material (see Plate 1). The first event was the evolution of a swollen bulla, giving the test a more spherical shape. Such forms are included within our broad concept of G. glutinata. This was followed by the first occurrence of individuals with more than one bulla overlapping (recorded as Globigerinatella sp.) and eventually areal apertures (recorded as G. insueta s. str.).

Correlation: Our concept of Globigerinatella insueta requires areal apertures as occur in the holotype and all the paratypes (Pearson, 1995). In Holes 925A and 929A, the base of G. insueta is a short distance below the top of Catapsydrax dissimilis. Similarly, the two species co-occur at the bottom of Hole 926A. In standard tropical zonations, the base of Zone N6 (= M3 of Berggren et al., 1995) is recognized by the base of "Globigerinatella insueta," but where such a datum should be placed in the gradual evolution of the lineage requires further study. Neither the base of Globigerinatella sp. or G. insueta as we define them correlates well with the supposed level of the base of Zone N6 in standard chronologies. Therefore, the two zones are not differentiated in this study pending a revision of this part of the tropical zonation.

\section{Top Globoquadrina binaiensis (19.1 Ma)}

Category: Extinction. Globoquadrina binaiensis disappeared from the record without leaving direct descendents.

Correlation: This proved to be one of the least successful datums for correlation between sites on the Ceara Rise, which is a function of the extreme rarity of the species in the higher part of its range. At Sites 925 and 926, the datum was found at or below the base of the nannofossil Sphenolithus belemnos, which is much lower than expected. At Site 928, dissolution was too intense to place the datum. At Site 929, several specimens of G. binaiensis were found in Sample 154-929A-28X-2, 70-72 cm, which lies within the reported range of $S$. belemnos and is at roughly the expected extinction level.

\section{Base Globigerinatella sp. (estimate for Ceara Rise: $20.2 \mathrm{Ma}$ )}

Category: Pseudospeciation. In our concept of Globigerinatella, we require evidence of superimposed bullae, usually small secondary bullae around a single chamberlike bulla (which is distinguished from a regular chamber by being more umbilically centered and possessing more than one aperture).

Correlation: Individuals attributed to Globigerinatella sp. occur among populations of Globigerinita glutinata in the lower part of Zone N5/6, below the base of the nannofossil Sphenolithus belemnos. 
This is at a lower level than traditionally assigned for the base of Zone N6; hence, we do not use the datum in that sense, and Zones N5 and N6 remain undifferentiated in this study (see discussion under $G$. insueta above).

\section{Top Paragloborotalia kugleri (21.6 Ma; base Zone N5/6/top Zone N4)}

Category: Extinction. Paragloborotalia kugleri probably left no lineal descendents, unless it can be established that it was ancestral to the Fohsella lineage.

Correlation: This datum appears to correlate well across the Ceara Rise sites at the expected level.

\section{Top Paragloborotalia pseudokugleri (original estimate: 23.3} Ma; revised estimate for Ceara Rise: $21.7 \mathrm{Ma}$ )

Category: Pseudospeciation. Because the morphospecies intergrades with Paragloborotalia kugleri, the placement of this datum depends critically on the definitions we employ. We restrict our concept of $P$. kugleri to include only those forms with strongly recurved dorsal sutures and an acute periphery.

Correlation: We have found individuals with relatively globular chambers and only moderately recurved dorsal sutures (P. pseudokugleri) through most of the range of $P$. kugleri on the Ceara Rise, at Sites $925,926,928$, and 929 . Other workers using a stricter definition of $P$. pseudokugleri would record a lower level for this datum. Note also that a third informal taxon in the lineage has been recognized by Spezzaferri (1994) as "P. pseudokugleri/P. kugleri transition." Consequently, none of our datums correspond in exact definition to hers.

\section{Base Globoquadrina dehiscens (timing poorly constrained)}

Category: Pseudospeciation. As has been established in other sections, Globoquadrina dehiscens evolved gradually from Globoquadrina praedehiscens.

Correlation: This datum can only be poorly constrained because of the rarity of $G$. dehiscens in the lower part of its range and intense dissolution on the Ceara Rise at those levels.

\section{Top "Globigerina" ciperoensis (estimate for Ceara Rise: 23.1 Ma)}

Category: Extinction. "Globigerina" ciperoensis disappeared from the record leaving no lineal descendents.

Correlation: "Globigerina" ciperoensis and Globigerinoides trilobus co-occur in the less dissolved Sites 925 and 926. The top of "Globigerina" ciperoensis on the Ceara Rise is therefore placed a little above the base of Paragoborotalia kugleri.

\section{Base Globigerinoides trilobus s.l. (estimate for Ceara Rise: 23.2 $\mathrm{Ma}$ )}

Category: Pseudospeciation. Globigerinoides trilobus s.l. evolved from the Zeaglobigerina connecta group by the acquisition of supplementary apertures.

Correlation: We employ a very broad concept of $G$. trilobus that encompasses various similar morphospecies usually separated by other workers. G. trilobus s.l. appears a short distance above the base of Paragloborotalia kugleri and the top of the nannofossil Sphenolithus delphix.

\section{Base Paragloborotalia kugleri (23.7 Ma; base Zone N4/top Zone P22)}

Category: Pseudospeciation.
Correlation: Paragloborotalia kugleri evolved by gradual transition from P. pseudokugleri. However, if a strict species definition is employed, we found that the datum correlates well across the Ceara Rise slightly above the top of the nannofossil Sphenolithus delphix. Our datum may be higher than other authors would recognize, if they employ a less strict definition for P. kugleri (see also Weedon et al., this volume).

\section{Top "Globigerina" angulisuturalis (23.3 Ma)}

Category: Extinction. "Globigerina" angulisuturalis appears to have become extinct without leaving any descendents.

Correlation: At Sites 925 and 926, the datum was placed a short distance above the top of the nannofossil Sphenolithus ciperoensis. In the more dissolved sediments of Sites 928 and 929, the uppermost recorded occurrence of "Globigerina" angulisuturalis was about $10 \mathrm{~m}$ below that datum. The datum is difficult to place because of a combination of marked abundance fluctuations of " $G$." angulisuturalis in the higher part of its range and its susceptibility to dissolution. Our data from Sites 925 and 926 are consistent with the view of Spezzaferri (1994) that the extinction of "Globigerina" angulisuturalis occurred earlier in the equatorial Atlantic than in the south Atlantic Ocean and in the Indian and Pacific Oceans.

\section{Base Paragloborotalia pseudokugleri (26.3 Ma)}

Category: Pseudospeciation. The earliest representatives of Paragloborotalia pseudokugleri are morphologically close to Paragloborotalia mayeri except that they are smaller and more tightly coiled.

Correlation: Interpolation between other datums suggests that Paragloborotalia pseudokugleri appeared slightly later on the Ceara Rise than elsewhere.

\section{Top Paragloborotalia opima (27.1 Ma; base Zone P22/top Subzone P21b)}

Category: Pseudoextinction. Paragloborotalia opima is the name given to large $(>390 \mu \mathrm{m})$ representatives of the Paragloborotalia nana lineage (Bolli and Saunders, 1985, p. 202).

Correlation: Although Paragloborotalia opima is a large species and prone to dissolution (some of our samples at this level consist only of fragments), the datum appears to correlate reasonably well across the Ceara Rise sites at the expected level (see also Weedon et al., this volume).

\section{Top Chiloguembelina cubensis (28.5 Ma; base Subzone P21b/ top Subzone P21a)}

Category: Extinction. Chiloguembelina cubensis apparently disappeared from the record without leaving any direct descendants.

Correlation: Chiloguembelina cubensis is very common in the fine fraction up to the datum. Although rare individuals have been found above the main population crash in other areas, none was found in the Leg 154 sites. This datum is very well characterized across the Ceara Rise and useful in establishing an Oligocene chronology (Weedon et al., this volume).

\section{Base "Globigerina" angulisuturalis (29.7 Ma; base Subzone P21a/top Zone P20)}

Category: Pseudospeciation. The origin of "Globigerina" angulisuturalis is by gradual transition from "Globigerina" ciperoensis.

Correlation: the base of "Globigerina" angulisuturalis correlates well across the Ceara Rise. 
31. Top Turborotalia ampliapertura (30.3 Ma; base Subzone P20/ top Zone P19)

Category: Extinction. Turborotalia ampliapertura disappeared from the record without leaving any descendant taxa.

Correlation: The extinction level of Turborotalia ampliapertura was found at approximately the expected level in Sites 925, 928, and 929 (see also Weedon et al., this volume).

\section{Top Pseudohastigerina naguewichiensis (32.5 Ma; base Zone} P19/top Zone P18)

Category: Extinction. Pseudohastigerina naguewichiensis disappeared without leaving any directly descendent taxa.

Correlation: Pseudohastigerina naguewichiensis is a rare component of the fine fraction immediately before its extinction. Dissolution at Site 929 was too intense to place the datum, but at Site 925 it was found slightly higher than expected, above the extinction of the nannofossil Reticulofenestra umbilicus (see also Weedon et al., this volume).

\section{Top Hantkenina alabamensis (33.75 Ma)}

Category: Extinction. Hantkenina alabamensis disappeared from the record without leaving any descendent taxa.

Correlation: This datum is used to recognize the Eocene/Oligocene boundary as defined in the Italian Appenines. Hantkenina alabamensis is rare immediately below its extinction level, which was found to be slightly higher than the top of T. cerroazulensis.

\section{Top Turborotalia cerroazulensis (33.9 Ma; base Zone P18/top Zone P17)}

Category: Extinction. Three morphospecies became extinct simultaneously in this event, namely Turborotalia cerroazulensis, Turborotalia cocoaensis, and Turborotalia cunialensis.

Correlation: At Site 925, the Turborotalia cerroazulensis lineage became extinct immediately before Hatkenina alabamensis in the latest Eocene.

\section{Top Cribrohantkenina inflata (34.0 Ma; base Zone P17/top Zone P16)}

Category: Pseudoextinction? It remains to be proved that the cribrohantkeninids possessing areal apertures are not merely variants of the Hantkenina lineage.

Correlation: Despite extensive recrystallization, which makes it difficult to distinguish some specimens of Cribrohantkenina from Hantkenina in these samples, this datum was found at its expected level in Hole 925A immediately below the top of Turborotalia cerroazulensis.

\section{Top Clavigerinella eocanica (estimate for Ceara Rise: 34.0 Ma)}

Category: Extinction. Neogene clavate species are mostly trochospiral and are apparently not descended from Clavigerinella.

Correlation: This datum occurs at a much higher level on the Ceara Rise than has been recorded from elsewhere (e.g., Blow, 1979; Toumarkine and Luterbacher, 1985). The highest individuals of this species were found only $2.5 \mathrm{~m}$ below the Eocene/Oligocene boundary, at the same level as the top of Cribrohantkenina.

\section{Base Turborotalia cunialensis (35.1 Ma)}

Category: Pseudospeciation. Turborotalia cunialensis is the final, keeled stage in the Turborotalia cerroazulensis lineage.
Correlation: Because of either poor preservation or its late arrival on the Ceara Rise, Turborotalia cunialensis was found in only two samples immediately below the extinction of the Turborotalia cerroazulensis group at Site 925.

\section{Top Turborotalia pomeroli (original estimate: $35.2 \mathrm{Ma}$ )}

Category: Pseudoextinction. The morphospecies Turborotalia pomeroli is part of the Turborotalia cerroazulensis lineage.

Correlation: We attribute a few specimens to Turborotalia pomeroli from samples in the lower part of Zone P16, higher than previously recorded. However, we do not attach much confidence to this observation because identifications are difficult to make in this poorly preserved material.

\section{Base Cribrohantkenina inflata (original estimate: $35.4 \mathrm{Ma}$; base Zone P16/top Zone P15)}

Category: Pseudospeciation?

Correlation: We did not find Cribrohantkenina inflata below Sample 154-925A-55R-1, 32-33 cm, but this is probably a function of its rarity and poor preservation.

40. Base Globigerinatheka semiinvoluta (original estimate: 38.8 Ma; base Zone P15/top Zone P14)

Category: Pseudospeciation.

Correlation: Globigerinatheka semiinvoluta is extremely rare in this poorly preserved material. We did not find the expected overlap in its range with those of the muricate genera Morozovella and Acarinina.

\section{Top Morozovella spinulosa (38.1 Ma)}

Category: Extinction. Morozovella spinulosa appears to have been the last surviving member of the genus.

Correlation: The top of the muricates Morozovella spinulosa and Acarinina spp. was at the same level in Site 925, although not as high as expected. Intense dissolution may account for this apparent truncation of its stratigraphic range.

\section{Top Orbulinoides beckmanni (40.2 Ma; base Zone P14/top Zone P13)}

Category: Extinction. Orbulinoides beckmanni became extinct without leaving any lineal descendants.

Correlation: Orbulinoides is tolerably abundant and dissolution resistant, making this a useful datum in both Sites 925 and 929.

\section{Base Orbulinoides beckmanni (40.6 Ma; base Zone P13/top Zone P12)}

Category: Dispersal? Despite the gradual transition described by Proto Decima and Bolli (1970), other authors have yet to confirm the observations.

Correlation: This datum was difficult to place at Site 925 because of downhole contamination of rock fragments. It was found at the expected level in Hole 929E.

\section{Top Morozovella aragonensis (43.7 Ma; base Zone P12/top Zone P11)}

Category: Extinction. Morozovella aragonensis apparently became extinct without leaving any direct lineal descendents.

Correlation: Despite the poor preservation, this datum was found at the expected level in Hole 929E. 


\section{Base Morozovella aragonensis (52.0 Ma; base Zone P7/top Zone P6)}

Category: Pseudospeciation. Morozovella aragonensis evolved by gradual transition from Morozovella lensiformis. The two forms are distinguished only by the number of chambers in the final whorl.

Correlation: This was the first datum we were able to locate below the middle Eocene, because of intense dissolution and recrystallization.

\section{Top Morozovella velascoensis (53.4 Ma; base Zone P6/top Zone P5)}

Category: Extinction. Eocene morozovellids appear to have been descended exclusively from the dextral Morozovella subbotinae group.

Correlation: We use this datum to approximate the Paleocene/ Eocene boundary. Note that Zone P5 of Berggren at al. (1995) and this study is equivalent to Subzone P6a of Berggren and Miller (1988) minus the short interval of overlap (newly recognized) in the ranges of G. pseudomenardii and Morozovella subbotinae. It also approximates Zone P6 of Blow (1979) and the Morozovella velascoensis Zone of Toumarkine and Luterbacher (1985).

\section{Top Globanomalina pseudomenardii (56.1 Ma; base Zone P5/ top Subzone P4c)}

Category: Extinction. Globanomalina pseudomenardii became extinct leaving no direct lineal descendants.

Correlation: Berggren and Miller (1988) thought that the top occurrence of G. pseudomenardii was always below the bases of Morozovella aequa and Acarinina soldadoensis, and they designated the gap between these ranges as their Zone P5. However, Berggren et al. (1995) now accept that G. pseudomenardii ranges a little higher than previously thought, although not into the lower Eocene as thought by Blow (1979) (see extended critique of this view in Berggren, 1982). Nevertheless, an overlap is identified by them and referred to as Subzone P4c. Subzone P4c is the lowermost zone recognized in Leg 154 sediments.

\section{SITE DESCRIPTIONS}

\section{Site 925}

\section{Introduction}

Site $925\left(4^{\circ} 12.26^{\prime} \mathrm{N}, 43^{\circ} 29.35^{\prime} \mathrm{W}\right)$ is the shallowest (water depth: $3041 \mathrm{~m}$ ) of the five sites drilled during Leg 154 and consequently has two important advantages over the other sites for planktonic foraminifer biostratigraphy. First, its relatively elevated bathymetry means that it is well above the present-day lysocline and was the most protected of the Ceara Rise sites during past periods of carbonate dissolution. Secondly, there is less evidence of downslope sedimentation processes, such as turbidites and slumps, than occurs in the deeper sites. Site 925 is located in a broad, relatively flat area in the middle of the Ceara Rise. Judging from the relative biostratigraphic continuity we encountered, the region does not appear to have been the source of significant sediment export for much of its history. However, a higher frequency of grain flows, slumps, and turbidites was recorded toward the lower part of the sequence, particularly in the Eocene interval (Curry, Shackleton, Richter, et al., 1995). These events are usually easy to identify using sedimentological criteria.

The early to middle Miocene transition (Zones N8-N9) was recovered in Hole $925 \mathrm{~A}$ by RCB, in Hole $925 \mathrm{C}$ by XCB, and in Hole $925 \mathrm{D}$ by APC. Of the five holes drilled at the site, only one (Hole 925A) penetrated far into the early Miocene and below. Planktonic foraminifer datums from the three holes are presented in Table 2.
Most of the present study was conducted in the rotary-cored Hole 925A. After two spot-cores, continuous drilling began with Core 154-925A-3R at 303.7 meters below seafloor (mbsf; Zone N11: middle Miocene) and terminated with Core 154-925A-69R at $930.4 \mathrm{mbsf}$ (Zone N12: middle Eocene). Recovery was generally good (the total recovery in the hole was $75.9 \%$ ), although several cores were empty, or nearly so. The lithology is pelagic carbonate throughout the sequence. A sharp transition from chalk to limestone was encountered in Core 154-925A-44R (Zone P19, lower Oligocene). Most foraminifer samples below this level show evidence of severe recrystallization, including overgrowth of tests and sparry infillings. However, it was possible to prepare sieved samples even in the most indurated sediments rather than resorting to thin section analysis.

A total of 197 samples from the study interval in Hole 925A was prepared and used in the construction of the datum table. Of these, 66 were selected for the purpose of constructing a range chart (Table 3).

\section{Miocene}

A moderately diverse assemblage typical of the low latitudes occurs throughout the sequence at Site 925. The most common elements of the middle Miocene include Globigerinoides spp., Dentoglobigerina altispira, Globoquadrina venezuelana, Globigerinita glutinata, Paragloborotalia mayeri and the fohsellids, but several other lineages are also consistently found.

Biostratigraphic subdivision of Cores $154-925 A-3 R$ and $4 R$ is based mainly on evolutionary transitions in the Fohsella lineage that are well displayed at this site, although they are difficult to pinpoint unambiguously because of the gradual nature of the transitions. Sample 154-925A-3R-1, 76-78 cm, clearly contains Fohsella "praefohsi" whereas no Fohsella fohsi was found and so it is assigned to Zone N11 (middle Miocene). The base of F. "praefohsi," which marks the base of Zone N11, is between Samples 154-925A-3R-2, $75-77 \mathrm{~cm}$, and 3R-3, 80-83 cm. The base of Fohsella peripheroacu$t a$, which marks the base of Zone N10, is between Samples 154925A-4R-2, 75-77 cm, and 4R-3, 77-79 cm. Zone N10 is considerably thinner at Site 925 than at Site 926, which may indicate some missing section (approximately $6 \mathrm{~m}$ ) between Cores 154-925A-3R and $4 \mathrm{R}$, or a mismatch in the composite section.

Members of the Praeorbulina-Orbulina group are relatively rare in the Ceara Rise sediments although the full range of morphologies is present and stratigraphic appearances are in the expected order. The rarity of the lineage can be only partly explained by dissolution, because some samples are tolerably well preserved. Biostratigraphic assignments based on the group have commonly been made on the basis of a few $(<10)$ specimens isolated from quite large samples; consequently, a degree of caution is recommended in the consideration of these datums. The base of Orbulina universa, which marks the base of Zone N9, is based on a single specimen found in Sample 154-925A-5R-2, 75-77 cm (although the species is more abundant immediately above). The base of Praeorbulina circularis is also in Core $154-925 \mathrm{~A}-5 \mathrm{R}$. This is probably a function of its extreme rarity because, in Site 926 and many other sections worldwide, $P$. circularis has been found well below the Orbulina datum. Praeorbulina glomerosa was found as low as Sample 154-925A-8R-6, 75-77 cm. The base of Praeorbulina sicana, which marks the base of Zone N8 (and is a controversial level; see "Biostratigraphic Correlation" section above), is between Samples 154-925A-10R-CC and 11R-1, 75-77 $\mathrm{cm}$. These latter datums indicate a more rapid sedimentation rate below the Orbulina datum than above, which may be partly a result of less intense dissolution.

Clavatorella bermudezi has a more restricted stratigraphic range on the Ceara Rise than elsewhere, occurring only from the highest part of Zone N8 to the lower part of Zone N10. It is always rare but can generally be found in large samples within its range. Both the base and top occurrences of this species are useful for regional correlations. 
Table 2. Planktonic foraminifer datums at Site $\mathbf{9 2 5}$ and their stratigraphic positions.

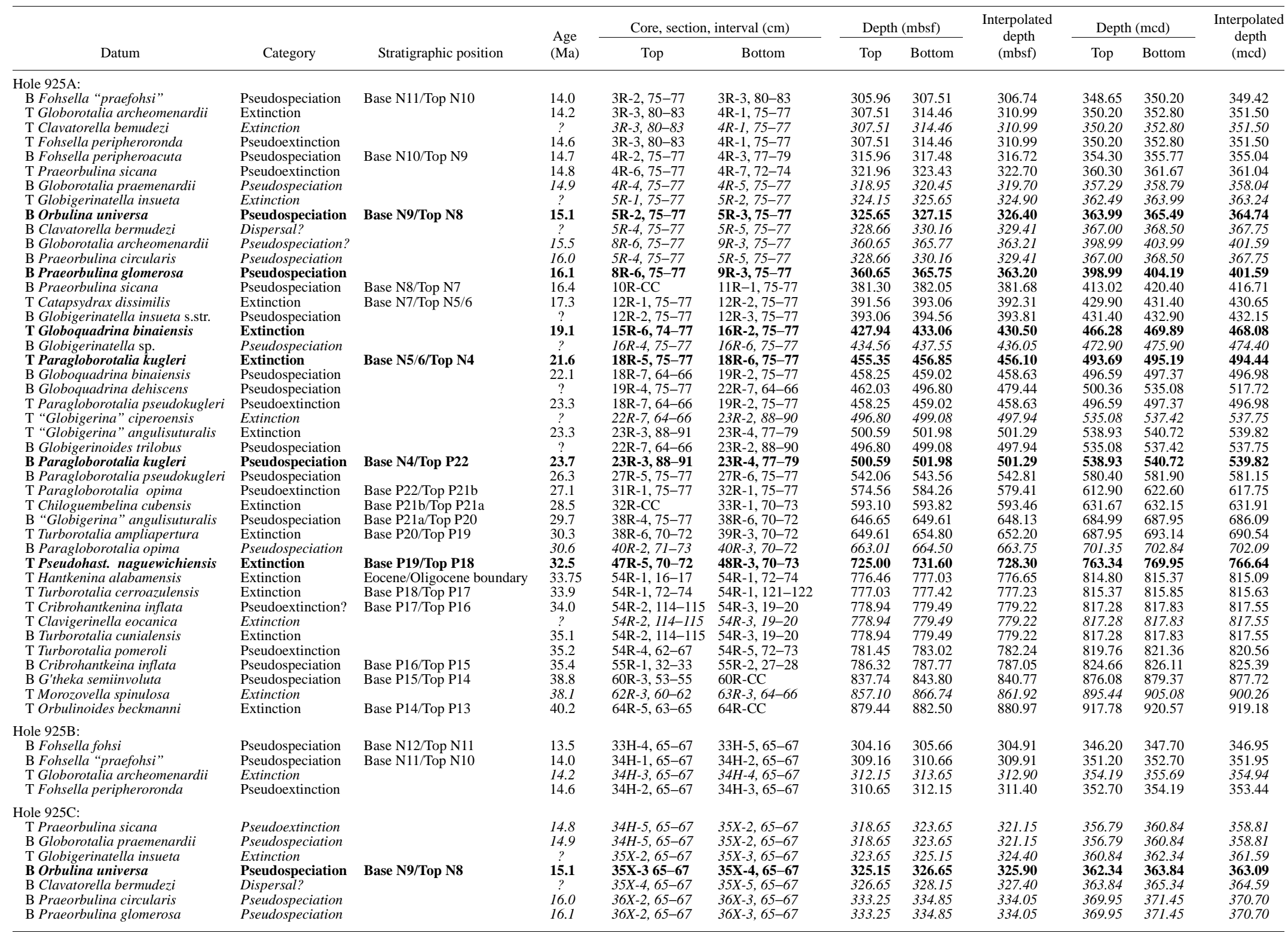

Notes: $\mathrm{B}=$ bottom occurrence, $\mathrm{T}=$ top occurrence, $\mathrm{mbsf}=$ meters below seafloor, $\mathrm{mcd}=$ meters composite depth. Datums in italics are in addition to those already published in Curry, Shackleton, Richter, et al. (1995). Datums in bold are amended. 
Table 3. Stratigraphic ranges of planktonic foraminifers in selected samples from Hole $925 \mathrm{~A}$

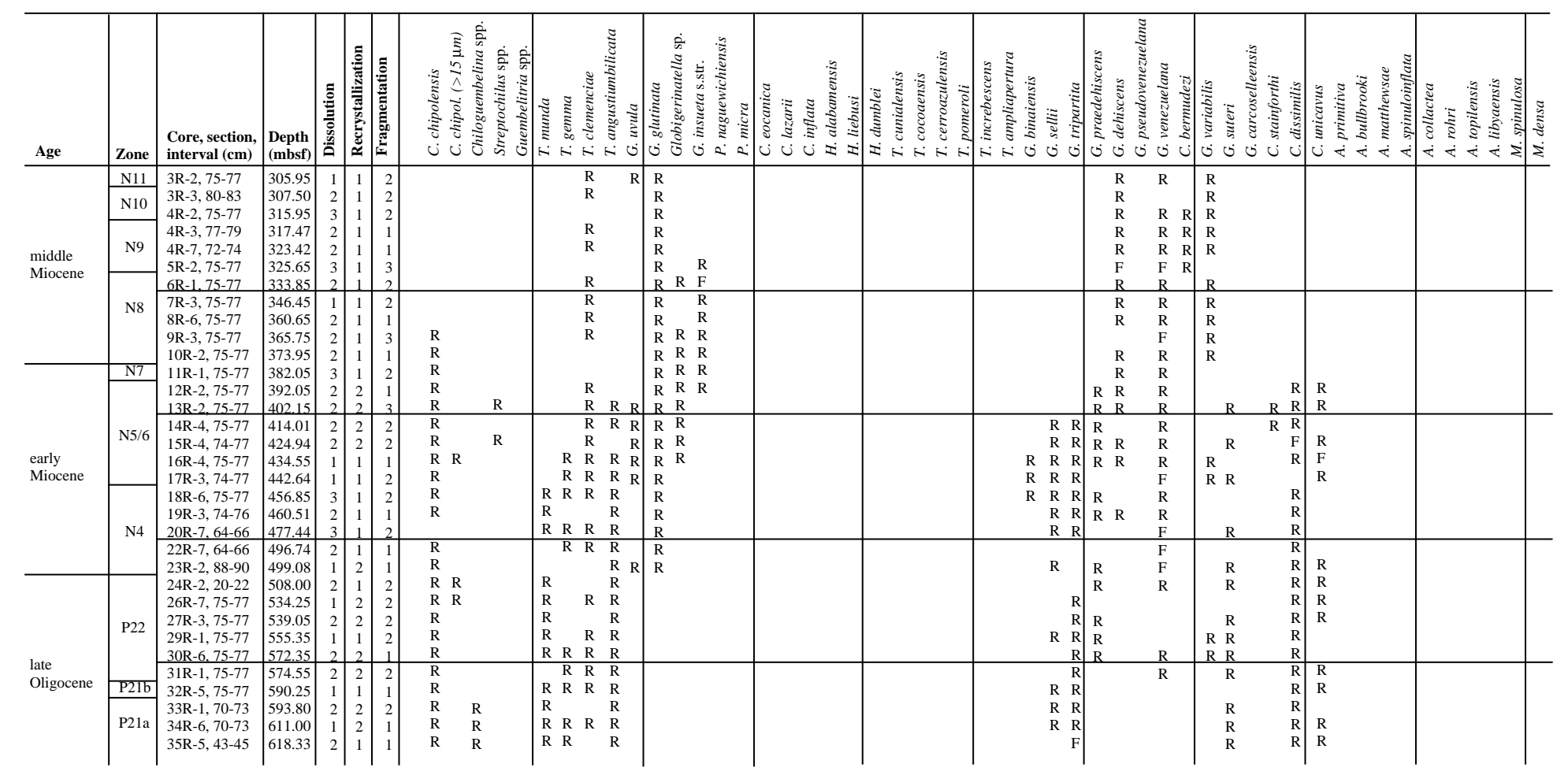


Table 3 (continued).

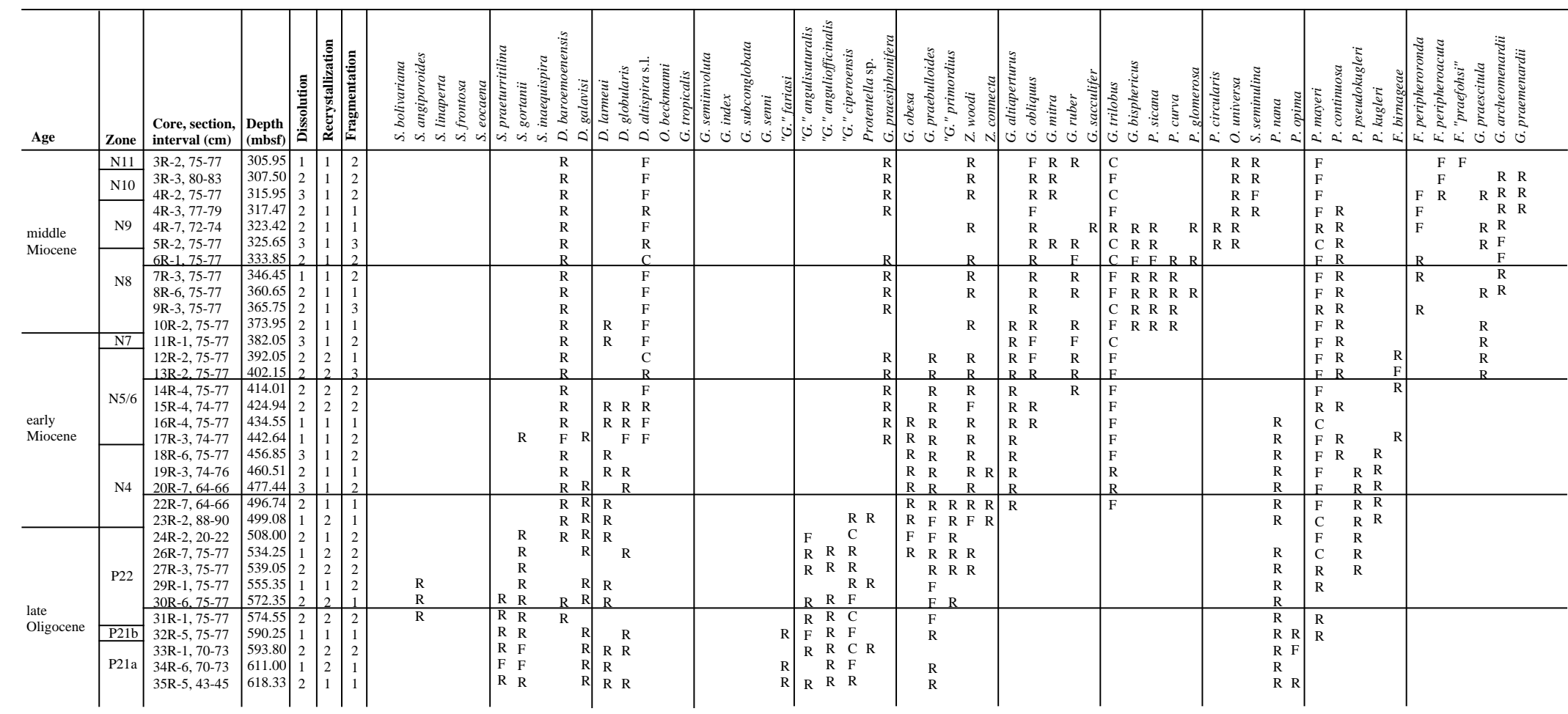




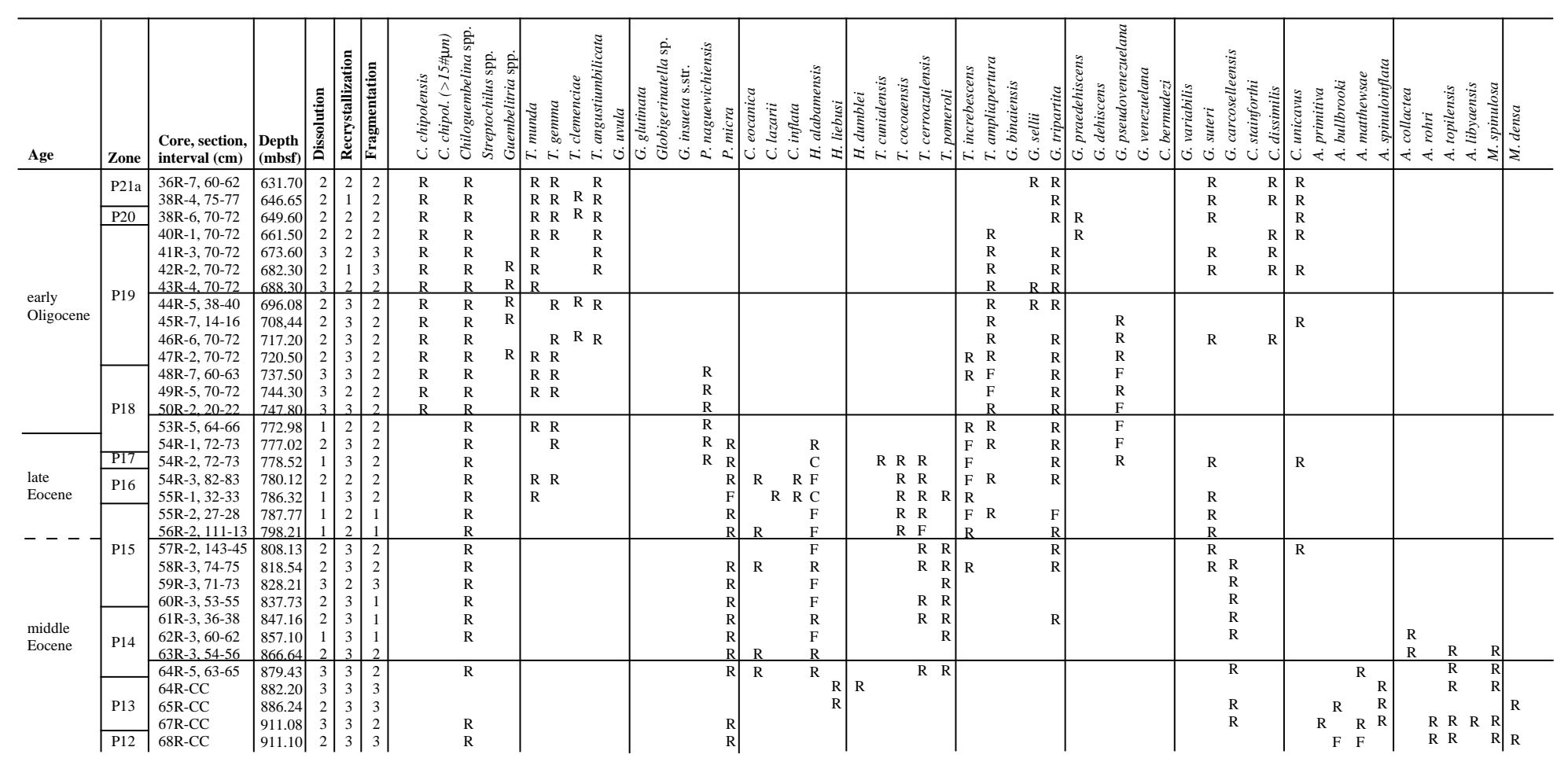

Note: $\mathrm{A}=$ abundant, $\mathrm{C}=$ common, $\mathrm{F}=$ frequent, $\mathrm{R}=$ rare, $1=$ light, $2=$ moderate, 3 = severe. 
Table 3 (continued)

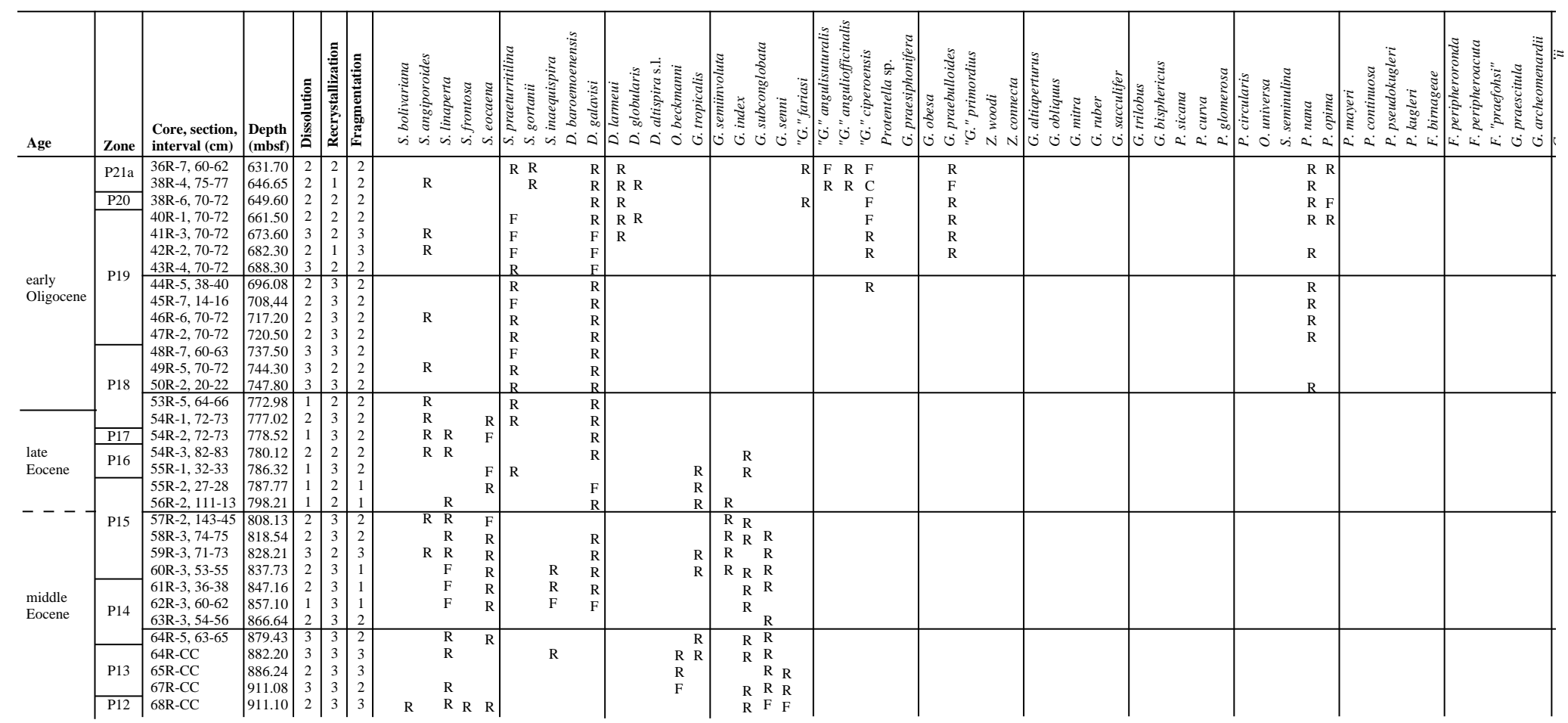


In contrast to Praeorbulina, Miocene catapsydracids are more common in the western Atlantic than, for example, the western Pacific. The top of Catapsydrax dissimilis, which marks the base of Zone N7, is between Samples 154-925A-12R-1, 75-77 cm, and 12R-2, $75-77 \mathrm{~cm}$. Catapsydrax unicavus has an identical extinction level to C. dissimilis at this site and may be a variety of the same biospecies.

The base of Zone N6 is usually recognized by the base of Globigerinatella insueta but this "event" does not appear to work at all on the Ceara Rise (see discussion in the "Biostratigraphic Correlation" section above). The lowest occurrence of Globigerinatella possessing areal apertures ( $G$. insueta s.str) is only slightly lower than the base of Zone N7. Forms possessing more than one generation of bullae (Globigerinatella sp.) occur only two cores above the top of Paragloborotalia kugleri. The only other event that is useful for correlation in the long Zone N5/6 interval is the top of Globoquadrina binaiensis, which is between Samples 154-925A-15R-6, 74-77 cm, and $16 \mathrm{R}-2,75-77 \mathrm{~cm}$. However, this is much lower than the corresponding level in Site 929, which reflects the rarity and intermittent occurrence of the species.

The top of Paragloborotalia kugleri, which marks the base of Zone N5/6, occurs between Samples 154-925A-18R-5, 75-77 cm, and 18R-6, 75-77 cm. Other common elements of lower Miocene faunas include globoquadrinids, dentoglobigerinids, Globigerinoides trilobus, and Paragloborotalia mayeri. The fine fraction is dominated by Cassigerinella chipolensis and Globigerinita glutinata. Catapsydrax, Zeaglobigerina, Globigerinella, and Tenuitella can also be found in almost all samples.

Zone N4 is not subdivided at this site because of the rarity of Globoquadrina dehiscens. The level of diversification of Globigerinoides occurs in the lower part of the zone between Samples 154925A-22R-7, 64-66 cm, and 23R-2, 88-90 cm, and includes the origin of both Globigerinoides trilobus (sensu lato) and Globigerinoides altiaperturus. The base of Paragloborotalia kugleri, which occurs as a gradual transition from Paragloborotalia pseudokugleri, and marks the base of Zone N4, is between Samples 154-925A-23R-3, 88-91 $\mathrm{cm}$, and 23R-4, 77-78 cm.

\section{Oligocene}

Planktonic foraminifers in the upper Oligocene are reasonably well preserved despite the sediment overburden of more than $500 \mathrm{~m}$. The Oligocene faunas have a very different aspect from those above, lacking true Globigerinoides (i.e., excepting "Globigerinoides" primordius) but containing many individuals belonging to the "Globigerina" ciperoensis group, including in some samples the distinctive form "Globigerina" angulisuturalis. Paragloborotalia mayeri is a frequent component, as it is through much of the Miocene above. Tenuitellinata angustiumbilicata occurs in addition to tenuitellids and Cassigerinella chipolensis in the fine fraction, but Globigerinita glutinata is absent. The limited data we have from adjacent samples in the light:dark lithologic bands (thought to be obliquity cycles at this level) points to a dramatic variation in faunal composition, with the paragloborotalids and "Globigerina" ciperoensis group in particular showing considerable abundance fluctuations.

"Globigerina" angulisuturalis was found in Sample 154-925A23R-4, 77-79 cm, which is just one section of core below the base of Paragloborotalia kugleri. This is at a considerably higher level than in the other Leg 154 sites and seems to indicate approximately $20 \mathrm{~m}$ of missing section in the uppermost Oligocene. Several planar fractures with slickensides were observed in Core 154-925A-23R (Curry, Shackleton, Richter, et al., 1995). It is therefore likely that the core represents an interval of normal faulting with multiple branching fault surfaces.

Paragloborotalia pseudokugleri is present, although infrequent, down to Sample 154-925A-27R-5, 25-27 cm. The top of Paragloborotalia opima, which marks the base of Zone P22, is between Samples 154-925A-31R-1, 75-77 cm, and 32R-1, 75-77 cm. No specimens of the biserial genus Chiloguembelina were found above Sample 154-925A-33R-1, 70-73 cm, but they are very common in the fine fraction of this sample and below. Chiloguembelina occurs consistently down to the middle Eocene, where recrystallization is so severe that specimens could not be isolated.

The base of Zone P21 is marked by the base of "Globigerina" angulisuturalis between Samples 154-925A-38R-4, 75-77 cm, and $38 \mathrm{R}-6,70-72 \mathrm{~cm}$. According to Blow (1979), both "G." angulisuturalis and the related form "Globigerina" ciperoensis evolved from a common ancestor, "Globigerina" anguliofficinalis, which was morphologically intermediate between the two. However, on the Ceara Rise the base of "G." anguliofficinalis-like morphologies coincides with the base of " $G$." angulisuturalis and they co-occur for much of the stratigraphic range of that form.

Turborotalia ampliapertura is found in Sample 154-925A-39R-3, $70-72 \mathrm{~cm}$, which is therefore assigned to Zone P19. Preservation deteriorates markedly as one descends through this thick zone, particularly at the chalk-limestone transition around Core 154-925A-44R. The base of Zone P19 is marked by the top of Pseudohastigerina naguewichiensis between Samples 154-925A-47R-5, 70-72 cm, and 48R-3, 70-73 cm. Pseudohastigerina is found very rarely in the poorly preserved fine-fraction samples at the top of its range, and is absent from the coarse fraction. It is more frequent lower down in the basal Oligocene, but even there it is still usually restricted to the fine $(<150 \mu \mathrm{m})$ fraction.

\section{Eocene}

Upper Eocene faunas are dominated by subbotinids (e.g., Subbotina eocaena), dentoglobigerinids, and globoquadrinids with the Turborotalia cerroazulenis lineage and the hantkeninids also occurring as common and distinctive components. The fine fraction is dominated by Chiloguembelina and the tenuitellids. The interval around the Eocene/Oligocene boundary was sampled more intensively than the rest of the sequence to ascertain the exact order of planktonic foraminifer extinctions, although we stress that the recrystallized nature of the sediment makes the site less than ideal for this purpose. The top of Hantkenina alabamensis is between Samples 154-925A-54R-1, $16-17 \mathrm{~cm}$, and $54 \mathrm{R}-1,72-73 \mathrm{~cm}$. However, it is very rare at this level, with only two fragmentary specimens having been found in the latter sample. Hantkenina is much more abundant (although still "rare" in comparison with the rest of the fauna) in Sample 154-925A54R-1, 121-122 cm. A second important extinction, which marks the base of Zone P18, is the top of the Turborotalia cerroazulensis group between Samples 154-925A-54R-1, 72-73 cm, and 54R-1, 121-122 $\mathrm{cm}$. A few questionable specimens of the compressed and keeled Turborotalia cunialensis morphotype were only found in Samples 154-925A-54R-1, 121-122 cm, and 54R-2, 114-115 cm, only, immediately below the extinction level of that lineage.

The top of Cribrohantkenina inflata, which marks the base of Zone P17, is between Samples 154-925A-54R-2, 114-115 cm, and $54 \mathrm{R}-3,19-20 \mathrm{~cm}$. Specimens are rare, often fragmentary, and sometimes difficult to distinguish from Hantkenina alabamensis in this heavily recrystallized material. A few poorly preserved specimens with areal apertures and a distinctly polygonal periphery were tentatively attributed to Cribrohantkenina lazarii. The base of Cribrohantkenina, which marks the base of Zone P16 (but may not be a very reliable datum as a result of the rarity of this form and the poor preservation), is between Samples 154-925A-55R-1, 32-33 cm, and 55R$2,27-28 \mathrm{~cm}$.

Globigerinathekids and related forms are usually rare in these dissolved and recrystallized sediments despite their thickly calcified tests. The base of Zone P15 is marked by the base of Globigerinatheka semiinvoluta between Samples 154-925A-60R-3, 53-55 cm, and 60R-CC. The lower few cores of Hole 925A are dominated by the subbotinids and various muricate forms, including Morozovella spinulosa, the "truncorotaloid" acarininids (Acarinina rohri and Ac- 
arinina topilensis) and the Acarinina bullbrooki/spinuloinflata plexus.

The distinctive large spherical form Orbulinoides beckmanni is an invaluable marker species in the lower part of the sequence at Site 925. Its top is used to mark the base of Zone P14 between Samples 154-925A-64R-5, 63-65 cm, and 64R-CC. The lowermost sample studied for planktonic foraminifers was Sample 154-925A-68R-CC. This consists of two rock fragments, both of which were examined. The fragments are of different ages. The first, which is marginally better preserved than the second, contains Orbulinoides beckmanni and so is assigned to Zone P13. The second does not contain Orbulinoides, but does contain "Subbotina" bolivariana, which indicates a substantially lower level. It is likely that the first fragment is a downhole contaminant, but the second may be in place and records a level in the middle or lower part of Zone P12.

\section{Site 926}

\section{Introduction}

Site $926\left(3^{\circ} 43.15^{\prime} \mathrm{N}, 42^{\circ} 54.50^{\prime} \mathrm{W}\right)$ is the third deepest of the five Leg 154 sites drilled on the Ceara Rise, at a water depth of $3598 \mathrm{~m}$. Three holes were drilled at the site. Hole 926A penetrated into Zone N5/6 (lower Miocene), Hole 926B into Subzone P21a (upper Oligocene) and Hole 926C into the lower Miocene. Samples were not taken from Hole 926C. Planktonic foraminifer datums for Holes 926A and 926B are given in Table 4, based on a total of 148 samples examined in the study interval. The faunal sequence at the site is very similar to Site 925 , as would be expected from the close proximity of the two sites, and so general features of the fauna will not be discussed in detail. Dissolution is more evident as would be expected from the deeper bathymetry. Oligocene through middle Miocene sediments are all chalky and show mostly minor evidence of calcite recrystallization.

\section{Miocene}

Datums in the lower part of the middle Miocene are more widely spaced than at Site 925 , indicating a slightly faster sedimentation rate. However, at Site 926 there is much less stratigraphic thickness between the base of Orbulina and the base of Praeorbulina sicana (i.e., Zone N8). At Site 925, Zone N8 is approximately $48 \mathrm{~m}$ thick, compared with only approximately $22 \mathrm{~m}$ in Hole 926B (these thicknesses are estimates because there is roughly a $1.5-\mathrm{m}$ uncertainty on each datum following our sample spacing). Closer inspection of the records suggests at least two levels of missing section, the first between the Orbulina datum and the top of the nannofossil Helicosphaera ampliaperta (i.e., at or near the core break between Cores 154-926B-31X and 32X), and the second between that nannofossil datum and the base of Praeorbulina glomerosa (i.e., within the first three sections of Core 154-926B-32X). These levels of suspected missing section also apply in Hole 926A. However, nothing out of the ordinary was noted in the visual core descriptions, except for drilling disturbance in Core 154-926B-31X and in Cores 154-926A-31H and $32 \mathrm{H}$.

There is a significant difference between the records in Holes 926A and 926B regarding the composite thickness of the bottom part of Zone N8. The bases of Praeorbulina glomerosa and Globorotalia archeomenardii are at similar composite depths in the two holes, but the base of Praeorbulina sicana and the top of Catapsydrax dissimilis are poorly aligned, suggesting about $6 \mathrm{~m}$ of missing section in Hole 926A between Cores 154-926A-32H and 33H. This is quite possible, because no attempt was made to align susceptibility or reflectance records at this depth in the two holes in the construction of the composite section (Curry, Shackleton, Richter, et al., 1995). One problem remains, though, in the placing of the nannofossil datum "top abundant Discoaster deflandrei," which, according to this view, ought to be placed in the core break between Cores 154-926A-32H and $33 \mathrm{H}$ instead of within Core 154-926A-33H as recorded in the shipboard report (Curry, Shackleton, Richter, et al., 1995).

The rest of the Miocene planktonic foraminifer biostratigraphy at Site 926 compares closely with the record at Site 925 despite the generally inferior preservation. One exception to this is the lower stratigraphic level of the top of Globoquadrina binaiensis in Hole 926B, which is probably because of the rarity and dissolution susceptibility of that species. Also noticeable in the lower Miocene of Site 926 is a greater proportion of radiolarian tests than at comparable levels at Site 925.

\section{Oligocene}

As noted above, the uppermost Oligocene (i.e., the interval between the top occurrence of "Globigerina" angulisuturalis and the base of Paragloborotalia kugleri) is mostly missing at Site 925 because of normal faulting. Thus, Site 926 (and also Sites 928 and 929, see below) illustrates the gradual evolution of Paragloborotalia pseudokugleri in the higher part of Zone P22. One interesting feature of this is that near the base of P. pseudokugleri, some individuals resemble in some respects $P$. kugleri s.str from much higher in the stratigraphic section, at least with respect to their slightly larger size than typical $P$. pseudokugleri and possession of more recurved dorsal sutures. It is possible that these forms could be referred to Paragloborotalia mendacis of Blow (1979). The rest of the Oligocene is similar to the other sites except that the top of Paragloborotalia opi$m a$ (i.e, the base of Zone P22 and top of Zone P21) is a little higher, possibly reflecting some variation in sedimentation rate across the region. The bottom-most sample analyzed, Sample 154-926B-64X-6, $70-72 \mathrm{~cm}$, contains "Globigerina" angulisuturalis and Chiloguembelina cubensis, and is, therefore, assigned to Subzone P21a.

A detailed isotopic study of upper Oligocene and lower Miocene planktonic foraminifers from Core $154-926 \mathrm{~B}-50 \mathrm{X}$ is presented in Pearson et al. (this volume).

\section{Site 927}

\section{Introduction}

Site $927\left(5^{\circ} 27.77^{\prime} \mathrm{N}, 44^{\circ} 28.84^{\prime} \mathrm{W}\right)$ is the second shallowest of the Leg 154 sites (at a water depth of $3315 \mathrm{~m}$ ). It is situated on a partially isolated plateau at the northwestern end of the ridge. Hole 927A was the deepest hole drilled at the site, which penetrated to $312.5 \mathrm{mbsf}$, into the lower part of Zone N8 (lower Miocene). Planktonic foraminifer datums from that hole are given in Table 5 based on an examination of 31 samples in the study interval.

\section{Miocene}

The study interval in Hole 927A contains at least two levels of missing section. The first is in the lower part of Core 154-927A-30H, where several stages in the evolution of the Fohsella lineage are missing. This jump corresponds to from a position within Zone N12 (Sample 154-927A-30H-5, 70-72 cm) to a position within the lower part of Zone N10 (Sample 154-927A-30H-CC), indicating a hiatus of approximately 2 m.y. Some redeposited sediment was noted between these samples in the visual core description (Curry, Shackleton, Richter, et al., 1995), and it is possible that an unconformity exists at the bottom of a small slump in Section 154-927A-30H-6. The second level of missing section is a little below this, between Samples 154927A-30H-CC and $31 \mathrm{H}-1,70-72 \mathrm{~cm}$. This corresponds to a jump between a position within the lower part of Zone N10 to a position within Zone N8 (approximately 1 m.y.). No unusual sedimentological features were noted at this level, which suggests that the unconformity may lie in the unrecovered core break. Because sediment supply to other sites on the Ceara Rise was continuous through these intervals, the missing sequences are probably because of episodes of downslope movement from the small plateau on which Site 927 is located. 
Table 4. Planktonic foraminifer datums at Site 926 and their stratigraphic positions.

\begin{tabular}{|c|c|c|c|c|c|c|c|c|c|c|c|}
\hline \multirow[b]{2}{*}{ Datum } & \multirow[b]{2}{*}{ Category } & \multirow[b]{2}{*}{ Stratigraphic position } & \multirow{2}{*}{$\begin{array}{l}\text { Age } \\
\text { (Ma) }\end{array}$} & \multicolumn{2}{|c|}{ Core, section, interval $(\mathrm{cm})$} & \multicolumn{2}{|c|}{ Depth (mbsf) } & \multirow{2}{*}{$\begin{array}{l}\text { Interpolated } \\
\text { depth } \\
\text { (mbsf) }\end{array}$} & \multicolumn{2}{|c|}{ Depth (mcd) } & \multirow{2}{*}{$\begin{array}{l}\text { Interpolated } \\
\text { depth } \\
\text { (mcd) }\end{array}$} \\
\hline & & & & Top & Bottom & Top & Bottom & & Top & Bottom & \\
\hline \multicolumn{12}{|l|}{ Hole 926A: } \\
\hline B Fohsella fohsi & Pseudospeciation & Base N12/Top N11 & 13.5 & $29 \mathrm{H}-2,25-27$ & $29 \mathrm{H}-3,10-12$ & 262.26 & 263.31 & 262.93 & 290.97 & 292.32 & 291.64 \\
\hline B Fohsella "praefohsi" & Pseudospeciation & Base N11/Top N10 & 14.0 & $30 \mathrm{H}-2,81-83$ & $30 \mathrm{H}-3,70-72$ & 272.31 & 273.70 & 273.01 & 301.42 & 302.81 & 302.11 \\
\hline T Fohsella peripheroronda & Pseudoextinction & & 14.6 & $30 \mathrm{H}-3,70-72$ & $30 \mathrm{H}-4,70-72$ & 273.70 & 275.20 & 274.45 & 302.81 & 304.31 & 303.56 \\
\hline $\mathrm{T}$ Globorotalia archeomenardii & Extinction & & 14.2 & $30 \mathrm{H}-4,70-72$ & $30 \mathrm{H}-6,70-72$ & 275.20 & 278.20 & 276.70 & 304.30 & 307.30 & 305.80 \\
\hline Т Clavatorella bemudezi & Extinction & & & $30 \mathrm{H}-3,70-72$ & $30 \mathrm{H}-4,70-72$ & 273.70 & 275.20 & 274.45 & 302.81 & 304.31 & 303.56 \\
\hline B Fohsella peripheroacuta & Pseudospeciation & Base N10/Top N9 & 14.7 & $31 \mathrm{H}-3,70-72$ & $31 \mathrm{H}-4,70-72$ & 283.20 & 284.70 & 283.95 & 312.31 & 313.81 & 313.06 \\
\hline T Praeorbulina circularis & Pseudoextinction & & 14.8 & $31 \mathrm{H}-4,70-72$ & $31 H-6,70-72$ & 284.70 & 287.70 & 286.20 & 313.80 & 316.80 & 315.30 \\
\hline B Globorotalia praemenardii & Pseudospeciation & & 14.9 & $31 \mathrm{H}-4,70-72$ & $31 \mathrm{H}-6,70-72$ & 284.70 & 287.70 & 286.20 & 313.80 & 316.80 & 315.30 \\
\hline $\mathrm{T}$ Globigerinatella insueta & Extinction & & & $31 \mathrm{H}-4,70-72$ & $31 H-6,70-72$ & 284.70 & 287.70 & 286.20 & 313.80 & 316.80 & 315.30 \\
\hline B Orbulina universa & Pseudospeciation & Base N9/Top N8 & 15.1 & $31 \mathrm{H}-6,70-72$ & $32 \mathrm{H}-2,70-72$ & 287.71 & 291.21 & 289.46 & 316.81 & 319.77 & 318.26 \\
\hline В Clavatorella bermudezi & Dispersal? & & & $31 \mathrm{H}-4,70-72$ & $31 \mathrm{H}-6,70-72$ & 284.70 & 287.70 & 286.20 & 313.80 & 316.80 & 315.30 \\
\hline B Globorotalia archeomenardii & Pseudospeciation? & & $1 \dot{5} .5$ & $32 \mathrm{H}-6,70-72$ & $33 \mathrm{H}-1,70-72$ & 297.20 & 299.20 & 298.08 & 325.77 & 328.31 & 327.04 \\
\hline B Praeorbulina circularis & Pseudospeciation & & 16.0 & $31 \mathrm{H}-6,70-72$ & $32 \mathrm{H}-2,70-72$ & 287.71 & 291.21 & 289.46 & 316.81 & 319.77 & 318.29 \\
\hline B Praeorbulina glomerosa & Pseudospeciation & & 16.1 & $32 \mathrm{H}-4,70-72$ & $32 \mathrm{H}-5,70-72$ & 294.21 & 295.71 & 294.95 & 322.77 & 324.27 & 323.52 \\
\hline B Praeorbulina sicana & Pseudospeciation & Base N8/Top N7 & 16.4 & $33 \mathrm{H}-3,70-72$ & $33 \mathrm{H}-4,70-72$ & 302.20 & 303.71 & 302.96 & 331.31 & 332.81 & 332.06 \\
\hline $\mathrm{T}$ Catapsydrax dissimilis & Extinction & Base N7/Top N5/6 & 17.3 & $33 \mathrm{H}-3,70-72$ & $33 \mathrm{H}-4,70-72$ & 302.20 & 303.71 & 302.96 & 331.31 & 332.81 & 332.06 \\
\hline \multicolumn{12}{|l|}{ Hole 926B: } \\
\hline B Fohsella peripheroacuta & Pseudospeciation & Base N10/Top N9 & 14.7 & $31 X-2,73-75$ & $31 X-3,73-75$ & 280.53 & 283.23 & 281.88 & 310.34 & 311.85 & 311.09 \\
\hline T Praeorbulina sicana & Pseudoextinction & & 14.8 & $31 X-3,73-75$ & $31 X-4,73-75$ & 283.23 & 284.74 & 283.98 & 311.85 & 313.35 & 312.60 \\
\hline B Globorotalia praemenardii & Pseudospeciation & & 14.9 & $31 X-3,73-75$ & $31 X-4,73-75$ & 283.23 & 284.74 & 283.98 & 311.85 & 313.35 & 312.60 \\
\hline $\mathrm{T}$ Globigerinatella insueta & Extinction & & & & $31 X-6,73-75$ & 284.74 & 286.53 & 285.63 & 313.35 & 316.35 & 314.85 \\
\hline B Orbulina universa & Pseudospeciation & Base N9/Top N8 & $1 \dot{5} .1$ & $31 X-6,73-75$ & $32 X-1,70-72$ & 286.53 & 288.70 & 287.62 & 316.35 & 318.52 & 317.43 \\
\hline B Clavatorella bermudezi & Dispersal? & Dase IV IOP IVO & 10.1 & $31 X-6,73-75$ & $32 X-1,70-72$ & 286.53 & 288.70 & 287.62 & 316.35 & 318.52 & 317.43 \\
\hline B Globorotalia archeomenardii & Pseudospeciation? & & 15.5 & $32 X-4,70-72$ & $32 X-6,70-72$ & 293.20 & 296.20 & 294.70 & 323.01 & 326.01 & 324.51 \\
\hline B Praeorbulina circularis & Pseudospeciation & & 16.0 & $32 X-2,70-72$ & $32 X-3,70-72$ & 290.20 & 291.70 & 290.95 & 320.02 & 321.52 & 320.77 \\
\hline B Praeorbulina glomerosa & Pseudospeciation & & 16.1 & $32 X-3,70-72$ & $32 X-4,70-72$ & 291.70 & 293.20 & 292.45 & 321.52 & 323.02 & 322.27 \\
\hline B Praeorbulina sicana & Pseudospeciation & Base N8/Top N7 & 16.4 & $34 X-3,70-72$ & $34 X-4,20-22$ & 311.01 & 312.01 & 311.51 & 340.32 & 341.82 & 341.06 \\
\hline T Catapsydrax dissimilis & Extinction & Base N7/Top N5/6 & 17.3 & $\mathbf{3 4 X}-\mathbf{3}, \mathbf{7 0 - 7 2}$ & $34 X-4,20-22$ & 311.01 & 312.01 & 311.51 & 340.32 & 341.82 & 341.06 \\
\hline B Globigerinatella insueta s.str. & Pseudospeciation & & $?$ & $34 X-3,70-72$ & $34 X-4,20-22$ & 311.01 & 312.01 & 311.51 & 340.32 & 341.82 & 341.06 \\
\hline $\mathrm{T}$ Globoquadrina binaiensis & Extinction & & 19.1 & $39 X-4,70-72$ & $39 X-5,70-72$ & 360.70 & 362.20 & 361.45 & 390.52 & 392.02 & 391.27 \\
\hline B Globigerinatell sp. & Pseudospeciation & & & $39 X-4,70-72$ & $39 X-5,70-72$ & 360.70 & 362.20 & 361.45 & 390.52 & 392.02 & 391.27 \\
\hline T Paragloborotalia kugleri & Extinction & Base N5-6/Top N4 & 21.6 & $44 \mathrm{X}-6,70-72$ & $45 \mathrm{X}-1,70-72$ & 411.60 & 413.80 & 412.70 & 441.41 & 443.61 & 442.51 \\
\hline T Paragloborotalia pseudokugleri & Pseudoextinction & & 23.3 & $45 X-2,70-72$ & $45 X-6,68-70$ & 415.30 & 421.30 & 418.30 & 445.09 & 451.29 & 448.19 \\
\hline B Globigerinoides trilobus & Pseudospeciation & & & $50 X-3,70-72$ & $50 X-4,70-72$ & 465.08 & 466.60 & 465.84 & 494.92 & 496.42 & 495.67 \\
\hline B Paragloborotalia kugleri & Pseudospeciation & Base N4/Top P22 & 23.7 & $50 X-3,70-72$ & $50 X-4,70-72$ & 465.08 & 466.60 & 465.84 & 494.92 & 496.42 & 495.67 \\
\hline T "Globigerina" ciperoensis & Extinction & Dase N4/IOp PLZ & $?$ & $55 X-2,70-72$ & $50 X-3,68-70$ & 463.60 & 465.08 & 464.34 & 493.41 & 494.92 & 494.16 \\
\hline 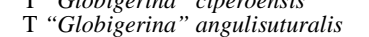 & $\begin{array}{l}\text { Extinction } \\
\text { Extion }\end{array}$ & & 23.3 & $52 X-6,65-67$ & $53 X-2,53-55$ & 488.65 & 492.33 & $\begin{array}{r}404.54 \\
490.49\end{array}$ & 518.44 & $\begin{array}{l}494.92 \\
522.04\end{array}$ & 520.24 \\
\hline B Paragl. pseudokugleri & Pseudospeciation & & 26.3 & $54 X-6,68-70$ & $55 \times-2,70-72$ & 508.08 & 511.70 & 509.89 & $\mathbf{5 3 7 . 8 9}$ & 541.51 & 539.70 \\
\hline T Paragloborotalia opima & Pseudoextinction & ase P22/Top P21b & 27.1 & $56 X-6,70-72$ & $57 X-1,70-72$ & 527.41 & 529.61 & 528.51 & 557.22 & 559.42 & 558.32 \\
\hline T Chiloguembelina spp. & Extinction & Base P21b/Top P21a & 28.5 & $61 X-4,70-73$ & $61 X-5,70-73$ & 572.81 & 574.31 & 573.56 & 602.62 & 604.12 & 603.37 \\
\hline
\end{tabular}

Notes: $\mathrm{B}=$ bottom occurrence, $\mathrm{T}$ = top occurrence, $\mathrm{mbsf}$ = meters below seafloor, $\mathrm{mcd}$ = meters composite depth. Datums in italics are additional to those already published in Curry, Shackleton, Richter, et al. (1995). Datums in bold are amended. 
Table 5. Planktonic foraminifer datums at Site $\mathbf{9 2 7}$ and their stratigraphic positions.

\begin{tabular}{|c|c|c|c|c|c|c|c|c|c|c|c|}
\hline \multirow[b]{2}{*}{ Datum } & \multirow[b]{2}{*}{ Category } & \multirow{2}{*}{$\begin{array}{l}\text { Stratigraphic } \\
\text { position }\end{array}$} & \multirow{2}{*}{$\begin{array}{l}\text { Age } \\
(\mathrm{Ma})\end{array}$} & \multicolumn{2}{|c|}{ Core, section, interval $(\mathrm{cm})$} & \multicolumn{2}{|c|}{ Depth (mbsf) } & \multirow{2}{*}{$\begin{array}{c}\text { Interpolated } \\
\text { depth } \\
(\mathrm{mbsf})\end{array}$} & \multicolumn{2}{|c|}{ Depth (mcd) } & \multirow{2}{*}{$\begin{array}{l}\text { Interpolated } \\
\text { depth } \\
\text { (mcd) }\end{array}$} \\
\hline & & & & Top & Bottom & Top & Bottom & & Top & Bottom & \\
\hline \multicolumn{12}{|l|}{ Hole 927A: } \\
\hline B Fohsella fohsi & Pseudospeciation & Base N12/Top N11 & 13.5 & $30 \mathrm{H}-5,70-72$ & $30 \mathrm{H}-\mathrm{CC}$ & 281.20 & 284.65 & 282.93 & 305.76 & 309.20 & 307.48 \\
\hline B Fohsella" "praefohsi" & Pseudospeciation & Base N11/Top N10 & 14.0 & $30 \mathrm{H}-5,70-72$ & $30 \mathrm{H}-\mathrm{CC}$ & 281.20 & 284.65 & 282.93 & 305.76 & 309.20 & 307.48 \\
\hline $\mathrm{T}$ Fohsella peripheroronda & Pseudoextinction & & 14.6 & $30 \mathrm{H}-5,70-72$ & $30 \mathrm{H}-\mathrm{CC}$ & 281.20 & 284.65 & 282.93 & 305.76 & 309.20 & 307.48 \\
\hline B Fohsella peripheroacuta & Pseudospeciation & Base N10/Top N9 & 14.7 & $30 \mathrm{H}-\mathrm{CC}$ & $31 \mathrm{H}-1,70-72$ & 284.65 & 284.70 & 284.68 & 309.20 & 309.26 & 309.23 \\
\hline B Globorotalia praemenardii & Pseudospeciation & & 14.9 & $30 \mathrm{H}-\mathrm{CC}$ & $31 \mathrm{H}-1,70-72$ & 284.65 & 284.70 & 284.68 & 309.20 & 309.26 & 309.23 \\
\hline B Orbulina universa & Pseudospeciation & Base N9/Top N8 & 15.1 & $30 \mathrm{H}-\mathrm{CC}$ & $31 \mathrm{H}-1,70-72$ & 284.65 & 284.70 & 284.68 & 309.20 & 309.26 & 309.23 \\
\hline B Globorotalia archeomenardii & Pseudospeciation? & & 15.5 & $30 \mathrm{H}-\mathrm{CC}$ & $31 \mathrm{H}-1,70-72$ & 284.65 & 284.70 & 284.68 & 309.20 & 309.26 & 309.23 \\
\hline B Praeorbulina glomerosa & Pseudospeciation & & 16.1 & $32 \mathrm{H}-7,33-35$ & $33 \mathrm{H}-1,70-72$ & 302.05 & 303.70 & 302.88 & 326.61 & 328.26 & 327.44 \\
\hline
\end{tabular}

Note: $\mathrm{B}=$ bottom occurrence, $\mathrm{T}=$ top occurrence, $\mathrm{mbsf}=$ meters below seafloor, $\mathrm{mcd}=$ meters composite depth.

Site 928

\section{Introduction}

Site $928\left(5^{\circ} 27.32^{\prime} \mathrm{N}, 43^{\circ} 44.89^{\prime} \mathrm{W}\right)$ is located on the gently sloping northern flank of the Ceara Rise at a water depth of $4012 \mathrm{~m}$. Situated in a position downslope of the ridge crest, it was more prone to receiving redeposited sediment than at the more elevated sites discussed previously. Three holes were drilled, of which Hole 928B penetrated the deepest, to $531 \mathrm{mbsf}$, into sediments assigned to Zone P19 (lower Oligocene). Hole 928A also penetrated below the middle Miocene, into Zone N8. The sequence at Site 928 is similar to that seen at the other sites on the Ceara Rise although dissolution is more evident than at the shallower sites. Planktonic foraminifer datums are given in Table 6 based on an examination of 129 samples in the study interval.

\section{Miocene}

Much of the middle Miocene at Site 928 is intensely dissolved, particularly Core 154-928B-22X and the correlative level in Hole 928A. Nevertheless, the base of Fohsella "praefohsi" can be located immediately below the level of most intense dissolution, between Samples 154-928B-23X-2, 70-72 cm, and 23X-4, 70-72 cm. Sample 154-928B-23X-4, 70-72 cm, contains Fohsella peripheroacuta in the absence of Fohsella peripheroronda indicating the higher part of Zone N10. Sample 154-928B-23X-6, 70-72 cm, contains both F. peripheroacuta and $F$. peripheroronda with Orbulina universa, indicating the lower part of that zone.

Sample 154-928B-24X-2, 70-72 cm, lacks Orbulina universa but contains several Praeorbulina morphospecies and Globigerinatella insueta, indicating the higher part of Zone N8. This sample was taken $20 \mathrm{~cm}$ above the beginning of an obviously slumped interval recorded on the visual core description. Judging from the core photograph, there are some indications above this sample that suggest that the same slump may extend as high as about interval 154-928B-24X-2, $40 \mathrm{~cm}$, in which case Sample 154-928B-24X-2, 70-72 cm, is transported. No evidence of Zone N9 was found below the slump, suggesting erosion at its base and missing section. The top of the same slump occurs in Hole 928A in the higher part of Section 154-928A-23X-6 and accounts for missing section in that hole also.

The base of Praeorbulina sicana, which marks the base of Zone N8, is between Samples 154-928B-26X-2, 61-63 cm, and 27X-2, $70-72 \mathrm{~cm}$. The latter sample also contains Catapsydrax dissimilis, so Zone N7 is either missing or very thin at this site. There is no sedimentologic evidence of faulting, slumping or a hiatus at this level, but Core 154-928B-26X was not fully recovered. In the lower Miocene, dissolution is less severe than in the middle Miocene, but still makes foraminifer biostratigraphy problematic. For example, Globoquadrina binaiensis could not be found at the level predicted from observations at other sites.

\section{Oligocene}

The base of Zone N5/6 is identified using the top of Paragloborotalia kugleri between Samples 154-928B-31X-3, 70-72 cm, and $31 \mathrm{X}-4,70-72 \mathrm{~cm}$. The upper part of the Oligocene appears to be complete at Site 928, as at Site 926. The top of "Globigerina" angulisuturalis is in Sample 154-928B-41X-5, 70-72 cm, considerably deeper than the correlative level in Site 926 based on nannofossil ranges. The low highest occurrence is probably a function of the enhanced dissolution at Site 928. Other Oligocene datums occur at approximately the level expected by extrapolation from other sites. The bottom-most sample analyzed, Sample 154-928B-56X-6, 70-72 cm, contains Turborotalia ampliapertura but no Pseudohastigerina naguewichiensis, and so is assigned to Zone P19.

\section{Site 929}

\section{Introduction}

Site $929\left(5^{\circ} 58.57^{\prime} \mathrm{N}, 43^{\circ} 44.39^{\prime} \mathrm{W}\right)$ is located down-slope of Site 928 on the northern flank of the Ceara Rise. It is the bathymetrically deepest site drilled during Leg 154 at a water depth of $4356 \mathrm{~m}$ and also penetrated the most sediment. Five holes were drilled, of which Hole 929E penetrated the deepest to 808.9 mbsf, into Subzone P4c (late Paleocene). Planktonic foraminifer datums for Holes 929A and 929E are given in Table 7 based on an examination of 99 samples in this study interval. A range chart of all species identified in the Paleocene (Subzone P4c) to middle Eocene (Zone P14) interval using 27 selected samples is given in Table 8 . The planktonic foraminifer biostratigraphy at this site was hampered by both intense dissolution in certain intervals and severe recrystallization.

\section{Miocene}

As at other sites on the Ceara Rise, the middle Miocene is affected by intense dissolution. The sediment is depleted in carbonate and many samples are barren of planktonic foraminifers. Sample 154929A-24X-6, 70-72 cm, is from a lighter colored band below the interval of most intense dissolution and is assigned to Zone N10 because it contains Fohsella peripheroacuta but no Fohsella "praefohsi." The next sample to contain planktonic foraminifers is Sample 154-929A-25X-4, 70-72 cm, which is assigned to Zone N8. Despite the fact that there appears to be no trace of the large slump that occurs at this level in Site 928, except for a 28-cm turbidite in Section 154929A-25X-2, the stratigraphic jump must represent a condensed interval or missing section. It may be that the slump in Site 928 and the turbidite in this site were deposited as part of the same event.

It was noted in the discussion for Site 928 that Zone N7 (the interval between the top of Catapsydrax dissimilis and the base of Praeorbulina sicana) is missing or of very short duration at that site. The same feature was observed at Site 929. Thus, Sample 154-929A- 
Table 6. Planktonic foraminifer datums at Site 928 and their stratigraphic positions.

\begin{tabular}{|c|c|c|c|c|c|c|c|c|c|c|c|}
\hline \multirow[b]{2}{*}{ Datum } & \multirow[b]{2}{*}{ Category } & \multirow[b]{2}{*}{ Stratigraphic position } & \multirow{2}{*}{$\begin{array}{l}\text { Age } \\
\text { (Ma) }\end{array}$} & \multicolumn{2}{|c|}{ Core, section, interval $(\mathrm{cm})$} & \multicolumn{2}{|c|}{ Depth (mbsf) } & \multirow{2}{*}{$\begin{array}{l}\text { Interpolated } \\
\text { depth } \\
\text { (mbsf) }\end{array}$} & \multicolumn{2}{|c|}{ Depth (mcd) } & \multirow{2}{*}{$\begin{array}{l}\text { Interpolated } \\
\text { depth } \\
\text { (mcd) }\end{array}$} \\
\hline & & & & Top & Bottom & Top & Bottom & & Top & Bottom & \\
\hline \multirow{6}{*}{$\begin{array}{l}\text { Hole 928A: } \\
\text { B Fohsella "praefohsi" } \\
\text { T Fohsella peripheroronda } \\
\text { B Fohsella peripheroacuta } \\
\text { B Orbulina universa } \\
\text { B Praeorbulina glomerosa }\end{array}$} & & & & & & & & & & & \\
\hline & Pseudospeciation & Base N11/Top N10 & 14.0 & $23 \mathrm{X}-1,70-72$ & $23 \mathrm{X}-2,70-72$ & 208.70 & 210.20 & 209.45 & 227.75 & 229.25 & 228.50 \\
\hline & Pseudoextinction & 年 & 14.6 & $23 \mathrm{X}-2,70-72$ & $23 \mathrm{X}-4,70-72$ & 210.20 & 213.20 & 211.70 & 229.25 & 232.25 & 230.75 \\
\hline & Pseudospeciation & Base N10/Top N9 & 14.7 & $23 \mathrm{X}-4,70-72$ & $23 \mathrm{X}-6,70-72$ & 213.20 & 216.20 & 214.70 & 232.26 & 235.26 & 233.76 \\
\hline & Pseudospeciation & Base N9/Top N8 & 15.1 & $23 \mathrm{X}-4,70-72$ & $23 \mathrm{X}-6,70-72$ & 213.20 & 216.20 & 214.70 & 232.26 & 235.26 & 233.76 \\
\hline & Pseudospeciation & & 16.1 & $25 \mathrm{X}-2,70-72$ & $25 X-3,70-72$ & 229.60 & 231.10 & 230.35 & 248.65 & 250.15 & 249.40 \\
\hline \multicolumn{12}{|l|}{ Hole 928B: } \\
\hline B Fohsella "praefohsi" & Pseudospeciation & Base N11/Top N10 & 14.0 & $23 \mathrm{X}-2,70-72$ & $23 \mathrm{X}-4,70-72$ & 206.70 & 209.70 & 208.20 & 226.44 & 229.44 & 227.94 \\
\hline $\mathrm{T}$ Fohsella peripheroronda & Pseudoextinction & & 14.6 & $23 \mathrm{X}-4,70-72$ & $23 \times-6,70-72$ & 209.70 & 212.70 & 211.20 & 229.44 & 232.44 & 230.94 \\
\hline B Fohsella peripheroacuta & Pseudospeciation & Base N10/Top N9 & 14.7 & $23 \mathrm{X}-6,70-72$ & $24 \mathrm{X}-2,70-72$ & 212.70 & 216.40 & 214.55 & 232.44 & 236.14 & 234.29 \\
\hline $\mathrm{T}$ Globigerinatella insueta & Extinction & & & $23 X-6,70-72$ & $24 X-2,70-72$ & 212.70 & 216.40 & 214.55 & 232.44 & 236.14 & 234.29 \\
\hline B Orbulina universa & Pseudospeciation & Base N9/Top N8 & 15.1 & $23 \mathrm{X}-6,70-72$ & $24 X-2,70-72$ & 212.70 & 216.40 & 214.55 & 232.44 & 236.14 & 234.29 \\
\hline B Globorotalia archeomenardii & Pseudospeciation? & & 15.5 & $24 \mathrm{X}-6,16-18$ & $25 \mathrm{X}-1,70-72$ & 221.86 & 224.60 & 223.23 & 241.60 & 244.34 & 242.97 \\
\hline B Praeorbulina glomerosa & Pseudospeciation & & 16.1 & $25 \mathrm{X}-2,70-72$ & $25 \mathrm{X}-3,70-72$ & 226.10 & 227.60 & 226 & 245.84 & 247.34 & 246.59 \\
\hline B Praeorbulina sicana & Pseudospeciation & Base N8/Top N7 & 16.4 & $26 \mathrm{X}-2,61-63$ & $27 \mathrm{X}-2,70-72$ & 235.21 & 245.40 & 240.30 & 254.95 & 265.15 & 260.04 \\
\hline T Catapsydrax dissimilis & Extinction & Base N7/Top N5-6 & 17.3 & & $27 \mathrm{X}-2,70-72$ & 235.21 & 245.40 & 240.30 & 254.95 & 265.15 & 260.04 \\
\hline B Globigerinatella insueta s.str & eciation & & & & & & 235 & 234. & 254.06 & 254.95 & 245.50 \\
\hline $\mathrm{T}$ Paragloborotalia kugleri & Extinction & Base N5-6/Top N4 & 21.6 & $31 \mathrm{X}-3,70-72$ & $31 X-4,70-72$ & 285.20 & 286.70 & 285.95 & 304.94 & 306.44 & 305.69 \\
\hline T Paragloborotalia pseudokugleri & Pseudoextinction & & 23.3 & $31 \mathrm{X}-4,70-72$ & $35 \mathrm{X}-2,70-72$ & 286.70 & 322.60 & 304.65 & 306.44 & 342.34 & 324.39 \\
\hline B Globigerinoides trilobus. & Pseudospeciation & & $?$ & $37 X-2,70-72$ & $37 X-4,70-72$ & 341.90 & 344.90 & 343.40 & 361.64 & 364.64 & 363.14 \\
\hline B Paragloborotalia kugleri. & Pseudospeciation & Base N4/Top P22 & 23.7 & $37 \mathrm{X}-5,70-72$ & $37 X-6,16-18$ & 346.40 & 347.36 & 346.88 & 366.14 & 367.10 & 366.62 \\
\hline $\mathrm{T}$ "Globigerina" ciperoensis & Extinction & & & $37 X-2,70-72$ & $37 X-4,70-72$ & 341.90 & 344.90 & 343.40 & 361.64 & 364.64 & 363.14 \\
\hline $\mathrm{T}$ "Globigerina" angulisuturalis & Extinction & & 23.3 & $41 X-4,70-72$ & $41 X-5,70-72$ & 382.04 & 383.54 & 382.79 & 401.78 & 403.28 & 402.53 \\
\hline B Paragloborotalia pseudokugleri & Pseudospeciation & & & $41 X-5,70-72$ & $41 X-6,70-72$ & 383.54 & 385.04 & 384.29 & 403.28 & 404.78 & 404.03 \\
\hline T Paragloborotalia opima & Pseudoextinction & Base P22/Top P21b & 27.1 & $44 X-4,66-68$ & $44 X-6,70-72$ & 411.56 & 414.60 & 413.08 & 431.34 & 434.34 & 432.84 \\
\hline T Chiloguembelina cubensis & Extinction & Base P21b/Top P21a & 28.5 & $46 \times-7,70-73$ & $46 \mathrm{X}-8,37-40$ & 433.24 & 434.91 & 434.58 & 453.98 & 454.65 & 454.31 \\
\hline B "Globigerina" angulisuturalis & Pseudospeciation & Base P21a/Top P20 & 29.7 & $50 \mathrm{X}-5,15-18$ & $51 \mathrm{X}-1,70-72$ & 470.35 & 474.60 & 472.48 & 490.09 & 494.34 & 492.22 \\
\hline T Turbor & & Base P20/Top P19 & 30.3 & & $51 \mathrm{X}-$ & 480.70 & 482.10 & 481.40 & 500.44 & 501.84 & 501.14 \\
\hline B Paraglo & dospeciation & & 30.6 & $52 X-1,70-72$ & $52 X-2,70-72$ & 484.30 & 485.80 & 485.05 & 504.04 & 505.54 & 504.79 \\
\hline
\end{tabular}

Notes: $\mathrm{B}=$ bottom occurrence, $\mathrm{T}$ = top occurrence, $\mathrm{mbsf}=$ meters below seafloor, $\mathrm{mcd}$ = meters composite depth. Datums in italics are additional to those already published in Curry, Shackleton, Richter, et al. (1995). Datum in bold is amended. 
Table 7. Planktonic foraminifer datums at Site 929 and their stratigraphic positions.

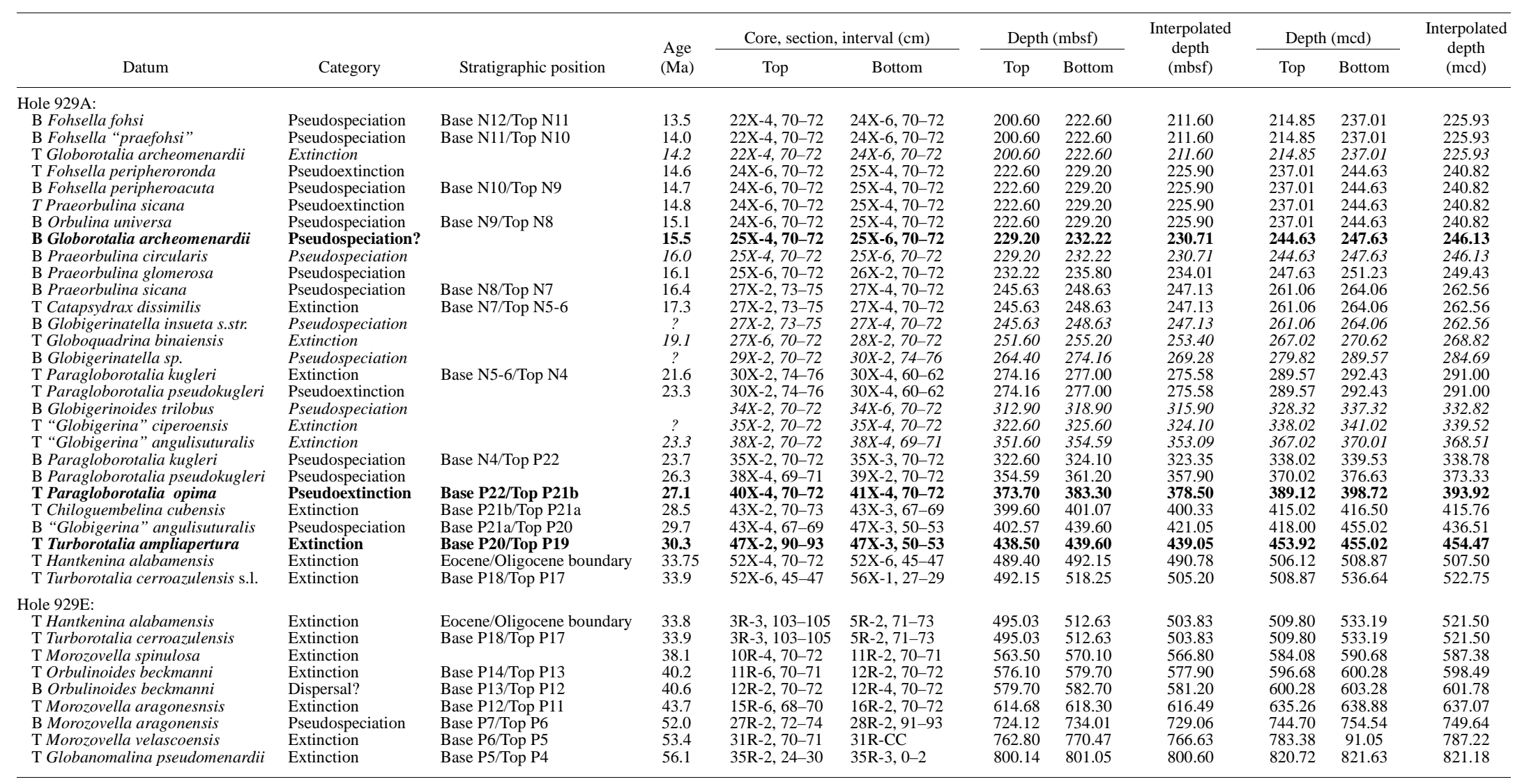

Notes: $\mathrm{B}=$ bottom occurrence, $\mathrm{T}=$ top occurrence, $\mathrm{mbsf}=$ meters below seafloor, $\mathrm{mcd}=$ meters composite depth. Datums in italics are additional to those already published in Curry, Shackleton, Richter, et al. $(1995)$. Datums in bold are amended. 


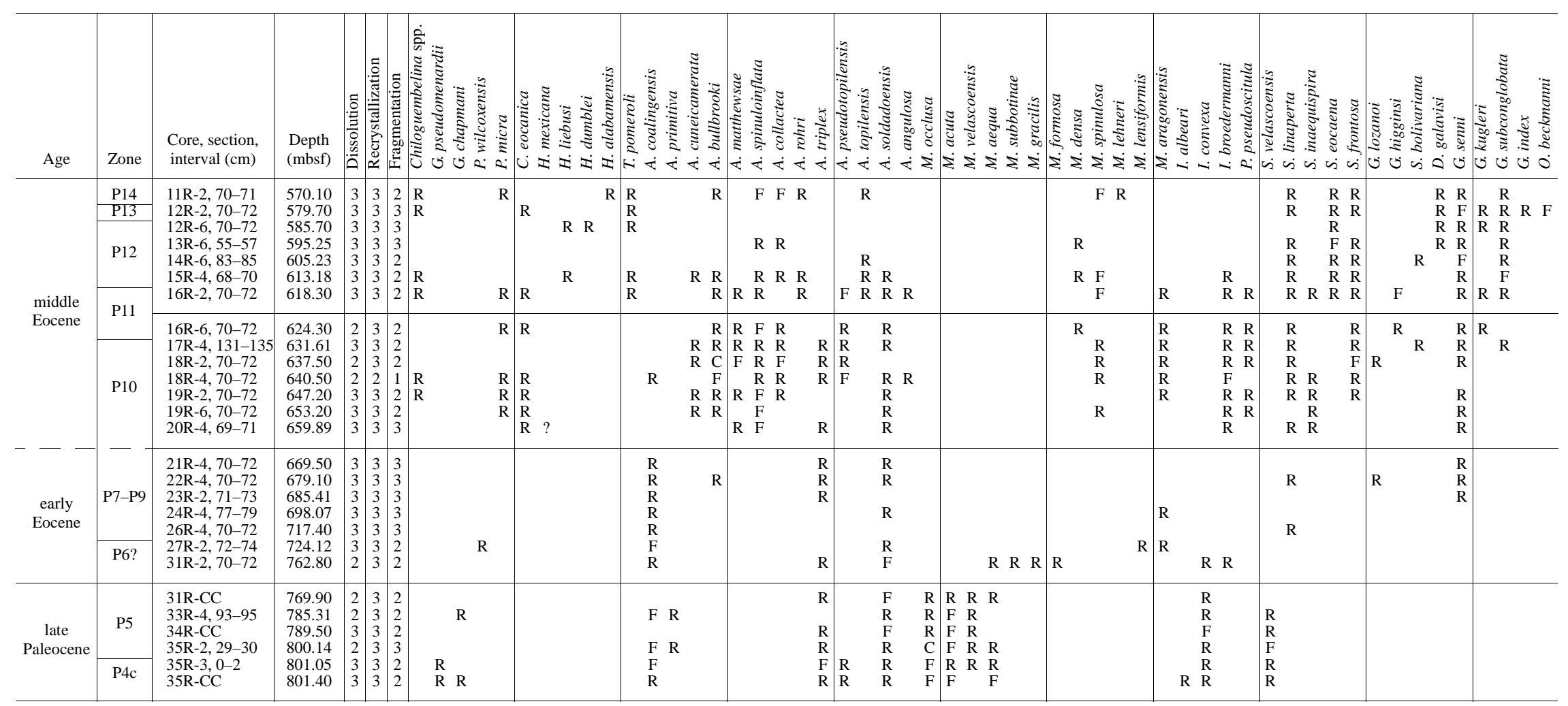

Note: $\mathrm{A}=$ abundant, $\mathrm{C}=$ common, $\mathrm{F}=$ frequent, $\mathrm{R}=$ rare, $1=$ light, $2=$ moderate, $3=$ severe. 
$27 \mathrm{X}-2,73-75 \mathrm{~cm}$, is assigned to Zone N8, whereas Sample 154929A-27X-4, 70-72 cm, is assigned to Zone N5/6. An intermediate sample from Section 154-929A-27X-3 is very poorly preserved and can not be assigned to a biozone. The stratigraphic gap coincides with a turbidite of approximately $1 \mathrm{~m}$ thickness, and thus it may be that erosion at the bottom of that turbidite accounts for missing section also.

Although Site 929 is the deepest and most dissolved site, it contains the highest recorded occurrence of the sporadically occurring species Globoquadrina binaiensis, in Sample 154-929A-28X-2, 70$72 \mathrm{~cm}$, at a level within the stratigraphic range of the nannofossil Sphenolithus belemnos.

\section{Oligocene}

The Oligocene record appears to be continuous, although poorly preserved, from Core 154-929A-30X to 43X, but Cores 154-929A$43 \mathrm{X}, 44 \mathrm{X}$, and $45 \mathrm{X}$ are complicated by slumping. The first occurrence of "Globigerina" angulisuturalis is poorly constrained. Sample 154-929A-43X-4, 67-69 cm, is moderately well preserved and contains very abundant "G." angulisuturalis. Sample 154-929A$44 \mathrm{X}-2,61-63 \mathrm{~cm}$, is also well preserved, but " $G$." angulisuturalis is absent. However, judging from the core photograph, this latter sample may have been taken from a thin $(\sim 5 \mathrm{~cm})$ turbidite or grain flow, although the feature was not noted in the visual core description. Additional evidence for this is furnished by the sample itself, which is very much more sorted with respect to grain size than the adjacent sediment. Much of the rest of Core 154-929A-44X is taken up by very homogeneous sediment that has been recorded as a suspected slump (Curry, Shackleton, Richter, et al., 1995). Samples taken from this interval all lack "G." angulisuturalis, but like Sample 154929A-44X-2, 61-63 cm, they too probably consist of slightly older reworked sediment. For some distance below this probable slumped interval, dissolution is so severe that few species of planktonic foraminifer remain. Because "G." angulisuturalis is thin-walled and dissolution-prone, its absence cannot be used to constrain its appearance level accurately. Only in Sample 154-929A-47X-3, 50-53 cm, can the absence of " $G$." angulisuturalis be confirmed, but that sample contains Turborotalia ampliapertura and so must be from a considerably lower level than that which corresponds to the first occurrence of "G." angulisuturalis worldwide and at other sites on the Ceara Rise. Similarly, dissolution prevents the recognition of Pseudohastigerina naguewichiensis at Site 929, so samples down to Sample 154929A-52X-4, 70-72 cm, were assigned to undifferentiated Zone P18-19.

\section{Eocene}

The Eocene/Oligocene boundary is marked by the top of Hantkenina alabamensis in the lowermost part of Zone P18. In both Holes 929A and 929E, the recognition of this boundary is made difficult by extreme dissolution. The highest unequivocal Eocene sample examined is Sample 154-929A-52X-6, 45-47 cm, which contains rare Hantkenina fragments but no Turborotalia cerroazulenis, and so is assigned to the lowermost part of Zone P18. Below this in Hole 929A, several samples were taken, which proved to be barren. No sample from the correlative level in Hole 929E was found to contain foraminifers. The highest Eocene sample in that Hole was Sample 154-929E-5R-2, 71-73 cm, which contains Turborotalia cerroazulensis and so is assigned to Zone P16/17 (i.e., a lower level than the highest unequivocal Eocene sample in Hole 929A).

Many samples in the middle and later Eocene are barren of planktonic foraminifers and most others are poorly preserved. Consequently, no datums were recognized in Cores 154-929E-6R through 10R. Samples in Cores 154-929E-11R and 12R, are sufficiently well preserved to assign tentative age estimates. Sample 154-929E-11R-2,
70-71 cm, contains various muricate species such as Morozovella spinulosa, Acarinina rohri, and Acarinina topilensis in association with rare Hantkenina alabamensis. This assemblage, in the absence of Orbulinoides beckmanni, indicates Zone P14. The top of Orbulinoides beckmanni, which marks the base of Zone P14, is between Samples 154-929E-11R-6, 41-43 cm, and 12R-2, 70-72 cm. The base of Zone P13, which is marked by the base of $O$. beckmanni, is between Samples 154-929E-12R-2, 70-72 cm, and 12R-4, 70-72 $\mathrm{cm}$. Despite the poor preservation, Zone P13 is of approximately the expected thickness.

Samples from Cores 154-929E-13R and 14R are either barren or very poorly preserved. Sample $154-929 \mathrm{E}-15 \mathrm{R}-4,68-70 \mathrm{~cm}$, is better preserved and contains Hantkenina liebusi, Acarinina soldadoensis, and Morozovella densa, but no Morozovella aragonensis and so is assigned to Zone P12. The top occurrence of Morozovella aragonensis, which marks the base of Zone P12, is between Samples 154-929E$15 \mathrm{R}-6,68-70 \mathrm{~cm}$, and 16R-2, 70-72 cm. Below this level in the Eocene, both recrystallization and severe dissolution affect faunal assemblages and many samples are barren. It is interesting that Hantkenina is absent in all samples below Zone P11 except for one possible chamber fragment in Sample 154-929E-20R-4, 69-71 cm, whereas the related form Clavigerinella eocanica was found in several samples through this interval. Perhaps Hantkenina was not present at this locality for much of that interval. Also present in the fine fraction of samples from Zones P10 and P11 is Planorotalites pseudoscitula. The base of Zone P10 was tentatively located between Samples 154-919E-20R-4, 69-71 cm, and 21R-4, 70-72 cm, on the basis of the base of $C$. eocanica and the single possible Hantkenina fragment discussed above. The zonal markers Globigerinatheka kugleri and Planorotalites palmerae are absent, so Zones P7 through P10 could not be differentiated.

The base of Morozovella aragonensis, which marks the base of Zone P7, is between Samples 154-929E-27R-2, 72-74 cm, and 28R$2,91-93 \mathrm{~cm}$. The former sample also contains intergrades between M. aragonensis and Morozovella lensiformis. Poor preservation is again a difficulty in Cores 154-929E-28R through 31R. The dominant morozovellid in these samples is dextrally coiled Morozovella subbotinae. Other species present include Morozovella aequa, Morozovella formosa, Igorina broedermanni, and several acarininids.

\section{Paleocene}

The Paleocene/Eocene boundary is approximated by the top occurrence of the Morozovella velasoensis group which marks the base of Zone P6. This datum occurs in a very poorly preserved interval between Samples 154-929E-31R-2, 70-72 cm, and 31R-CC. Typical M. velascoensis differs from Morozovella subbotinae by possessing more chambers in the final whorl, a more highly vaulted umbilical side, a deeper and more open umbilicus, and stronger ornamentation. In this site, the sensu stricto form of Morozovella velascoensis is rare in comparison to the related forms Morozovella acuta and Morozovella occlusa with which it intergrades and which disappear at the same level. These three morphospecies are believed to belong to a single lineage that is further distinguished from $M$. subbotinae by being sinistrally coiled, whereas the latter is usually dextral.

In addition to the morozovellids, Paleocene samples contain several species of Acarinina and Subbotina spp., and Igorina convexa. No trace of the fascinating late Paleocene thermal maximum "excursion fauna" described by Kelly et al. (1995) from the equatorial Pacific was found at this site, but this may be because of either poor preservation or our relatively coarse sampling. The top of Globanomalina pseudomenardii, which marks the base of Zone P5, occurs between Samples 154-929E-35R-2, 29-30 cm, and 35R-3, 0-2 cm. The lowermost sample examined, Sample 154-929E-35R-CC, contains both Globanomalina pseudomenardii and Acarinina soldadoensis and so is assigned to Subzone P4c. 


\section{CONCLUSIONS}

The planktonic foraminifer biostratigraphy presented here replaces that published in Curry, Shackleton, Richter, et al. (1995). In this study we have attempted to pinpoint datums to within a sampling resolution of $1.5 \mathrm{~m}$, which equates to a time interval on the order of 100 k.y., given a typical sedimentation rate for the region (although sedimentation rates vary considerably in time and between sites). The majority of important datums were successfully located at each of the five sites. In general, the sequences at the different sites were extremely similar to one another, although there are differences in preservation because of enhanced dissolution at the deeper sites. Several minor unconformities, faults, and reworked intervals have been recognized using planktonic foraminifers.

Because the planktonic foraminifers are a very well-known fossil group, there are few surprises in the stratigraphic ranges of the species we studied. However, we would draw the attention of other taxonomists and biostratigraphers to two discoveries in particular: (1) the well-displayed gradual transition between Globigerinita and Globigerinatella, similar to that previously described from the Pacific (Pearson, 1995); and (2) the persistence of Clavigerinella to a level near the Eocene/Oligocene boundary.

The sedimentary system on the Ceara Rise has been unusually sensitive to climatic variation for much of its Cenozoic history. Sediments have accumulated in a remarkably continuous manner at the more elevated sites. This combination of factors means that the five sites drilled on Leg 154 will be used in the development of an orbitally tuned time scale for much of the Cenozoic. Progress toward this goal is presented in other papers in this volume. The exciting prospect for calcareous microfossil biostratigraphy on the Ceara Rise is that datums may ultimately be calibrated directly to an orbital time scale (astrochronology). Such a method is independent of the usual approach based on identifying the positions of datums relative to paleomagnetic reversals, and is potentially much more accurate (Berggren et al., 1995). For the older parts of the record, even if an absolute age cannot be obtained in this way, it should still be possible to estimate the durations between datums accurately using astrochronology (e.g., Weedon et al., this volume). We have described in detail our species concepts and criteria for recognizing datums so that future workers will be able to use this study as a general framework for high-resolution sampling in specific intervals of interest.

\section{SYSTEMATIC TAXONOMY}

As has been argued elsewhere (Fordham, 1986; Pearson, 1992, 1993), Linnaean taxonomy cannot provide a natural classification when evolution within lineages (anagenesis) is encountered, as is commonly the case in the planktonic foraminifer record. Nevertheless, the typological approach remains the only practical approach to biostratigraphy and has the great advantage of being workable even in parts of the record that are poorly understood. All taxa identified in this study are regarded by the authors strictly as morphological units (morphospecies) that often intergrade with one another through intermediates. As such, neither they nor their stratigraphic ranges can be assumed to have an objective meaning except with reference to the arbitrary taxonomic decisions we are forced to make in their definition. Because we do not employ a "biological" species concept, we have not hesitated in splitting, for example, Paragloborotalia opima from $P$. nana on the basis of size alone because there is stratigraphic value in doing so. Other so-called species have been lumped where (1) it is not obvious that they are biologically separate and (2) their subdivision has no obvious stratigraphic utility. For simplicity, we have avoided the subgenus and subspecies categories.

The taxonomy presented below is a conservative one. Extended discussions of almost all of the species listed below can be found in the following important synthetic works: Loeblich and Tappan (1957) and other papers in the same volume; Postuma (1971); Blow (1979); Kennett and Srinivasan (1983); and Spezzaferri (1994). Full references for the type descriptions can be found in those works.
Acarinina angulosa (Bolli)

Globigerina soldadoensis angulosa Bolli, 1957, p. 71, pl. 16, figs. 4-6.

Acarinina angulosa is a variety of Acarinina soldadoensis but has more angular chambers and a more irregular shape.

Acarinina bullbrooki (Bolli)

Globorotalia bullbrooki Bolli, 1957, p. 167, pl. 38, figs. 4a-5c.

The name Acarinina bullbrooki is applied to large, plano-convex acarininids with four chambers in the final whorl. See comments under Acarinina spinuloinflata and Acarinina matthewsae.

Acarinina coalingensis (Cushman and Hanna)

Globigerina coalingensis Cushman and Hanna, 1927, p. 219, pl. 14, figs. 4a$4 \mathrm{~b}$.

Acarinina coalingensis is a compact, rounded, and coarsely muricate form with three to four chambers in the final whorl. It differs from Acarinina primitiva by lacking the high apertural face characteristic of that species. In comparison with the other muricate species, it seems to be dissolution resistant, and therefore is one of the few species recognized in the lower Eocene in Site 929.

\section{Acarinina collactea (Finlay)}

Globorotalia collactea Finlay, 1939, p. 327, pl. 29, figs. 164-165.

Acarinina collactea is a small rounded form with five chambers in the final whorl. In some samples it is the dominant muricate species. Because of poor preservation, it is impossible to tell whether all the specimens assigned to this species possess supplementary apertures on the spiral side.

\section{Acarinina cuneicamerata Blow}

Globorotalia (Acarinina) cuneicamerata Blow, 1979, p. 925-926, pl. 156, figs. $1-4$; pl. 165, figs. 4 and 7; pl. 203, fig. 5.

Acarinina cuneicamerata has a similar morphology to Acarinina bullbrooki, but it is less tightly coiled and possesses five chambers in the final whorl.

Acarinina libyaensis (El Khoudary)

Truncorotaloides libyaensis El Khoudary, 1977, p. 330, pl. 2, fig. 1.

Acarinina libyaensis is a variant of Acarinina topilensis, possessing at least five chambers in the final whorl. As in A. topilensis, supplementary sutural apertures usually occur on the spiral side.

\section{Acarinina matthewsae Blow}

Globorotalia (Acarinina) matthewsae Blow, 1979, p. 935-937, pl. 170, figs. 1-9; pl. 179, figs. $1-2$; pl. 187, fig. 5; pl. 203, figs. $3-4$; pl. 204, figs. $1-$ 5; pl. 205, figs. $1-6$.

Acarinina matthewsae is a quadrate acarininid similar to Acarinina bullbrooki, but it is generally smaller and more tightly coiled. The chambers appear flat and deflated in dorsal view.

Acarinina primitiva (Finlay)

Globoquadrina primitiva Finlay, 1947, p. 291, pl. 8, figs. 129-134.

Acarinina primitiva is distinguished from Acarinina coalingensis by the high apertural face of the final chamber, a feature which gives the species a general resemblance to Globoquadrina dehiscens. The development of the apertural face is a variable feature and $A$. primitiva seems to intergrade with $A$. coalingensis in the late Paleocene of Site 929. 


\section{Acarinina pseudotopilensis Subbotina}

Acarinina pseudotopilensis Subbotina, 1953, p. 227, pl. 21, figs. 8a-9c; pl. 22 , figs. $1 \mathrm{a}-3 \mathrm{c}$.

Both Acarinina pseudotopilensis and Acarinina triplex were described by Subbotina (1953) from the upper Paleocene of the Caucasus. The two forms are similar and are distinguished by the smaller size and less inflated chambers of A. pseudotopilensis. The evolution of the two forms was apparently a complicated process, with the A. pseudotopilensis morphotype possibly evolving more than once (see Pearson et al., 1993). This could account for its disjunct range in Leg 154 sediments (alternatively, enhanced dissolution in the early Eocene could provide the explanation).

Acarinina rohri (Brönnimann and Bermudez)

Truncorotaloides rohri Brönnimann and Bermudez, 1953, p. 818-819, pl. 87, figs. 7-9.

Acarinina rohri possesses at least one supplementary sutural aperture. It is distinguished from Acarinina topilensis by its more circular equatorial profile.

Acarinina soldadoensis (Brönnimann)

Globigerina soldadoensis Brönnimann, 1952, pp. 9-11, pl. 1, figs. 1-9.

Acarinina soldadoensis is a large acarininid with angular chambers and a tendency to develop blocky muricae on the umbilical shoulders. The style of chamber addition is slightly irregular, leading to an untidy test. Blow (1979) included the species in his genus Muricoglobigerina because of the umbilical aperture seen in some specimens. However, this feature is not seen in all specimens and may result geometrically from the irregular chamber addition. $A c$ arinina soldadoensis has a long range, from the upper Paleocene to the middle Eocene.

$$
\text { Acarinina spinuloinflata (Bandy) }
$$

Globigerina spinuloinflata Bandy, 1949, p. 122, pl. 23, figs. 1a-c.

Globigerina spinuloinflata Bandy, Cifelli 1972, p. 158, pl. 1, figs. $2 \mathrm{a}-\mathrm{c}$ (holotype redescribed).

Acarinina spinuloinflata is distinguished from Acarinina bullbrooki by having more rounded, inflated chambers. It is distinguished from Acarinina triplex by being flatter on the spiral side and having less incised dorsal sutures. Intermediates between A. spinuloinflata and A. bullbrooki are common.

\section{Acarinina topilensis (Cushman)}

Globigerina topilensis Cushman, 1925, p. 7, pl. 1, figs. 9a-c.

Acarinina topilensis is distinguished from Acarinina pseudotopilensis by having more angular chambers and dorsal supplementary apertures. See also comments under Acarinina rohri and Acarinina libyaensis.

\section{Acarinina triplex Subbotina}

Acarinina triplex Subbotina, 1953, p. 230, pl. 23, figs. 1a-5c.

Acarinina triplex is an inflated acarininid closely related to Acarinina pseudotopilensis. It shares with that species incised sutures and four rounded chambers in the final whorl, but it is distinguished by the larger size and more inflated chambers. It is distinguished from Acarinina coalingensis by its larger size, more open umbilicus, and more incised sutures.

\section{Cassigerinella chipolensis (Cushman and Ponton)}

Cassidulina chipolensis Cushman and Ponton, 1932, p. 98, pl. 15, figs. 2a-c.

Cassigerinella chipolensis is a distinctive microperforate form with ovate chambers and an irregular style of chamber addition. Included with this taxon are the more flattened varieties that some authors would assign to Cassigerinella globosa. In Leg 154 material it ranges from the lower Oligocene (Zone $\mathrm{P} 18$ ) to the lower Miocene (Zone N8) and is often very abundant in the fine $(<150 \mu \mathrm{m})$ fraction. It is rare toward the bottom of its stratigraphic range, pos- sibly because of poor preservation. The occurrence of large $(>150 \mu \mathrm{m})$ individuals at certain levels (e.g., Sample 154-925A-26R-7, 75-77 cm, in Zone P22) appears to be of stratigraphic utility (see Spezzaferri, 1994).

\section{Catapsydrax dissimilis (Cushman and Bermudez)} Plate 2, Fig. 12

Globigerina dissimilis Cushman and Bermudez, 1937, p. 25, pl. 3, figs. 4a-c.

Catapsydrax dissimilis is distinguished from Catapsydrax unicavus by the presence of more than one infralaminal accessory aperture around the bulla, which is usually more centrally placed in the umbilicus. It is very rare in the Eocene of Site 925, but more common in the Oligocene and lower Miocene.

Catapsydrax stainforthi Bolli, Loeblich and Tappan

Catapsydrax stainforthi Bolli, Loeblich and Tappan, 1957, p. 37, pl. 7, figs. $11 \mathrm{a}-\mathrm{c}$.

Catapsydrax stainforthi is distinguished from Catapsydrax dissimilis by having more rapidly expanding chambers and a flatter bulla. In this study it was found only in the lower Miocene.

\section{Catapsydrax unicavus Bolli, Loeblich and Tappan}

Catapsydrax unicavus Bolli, Loeblich and Tappan, 1957, p. 37, pl. 7, figs. 9ac.

Catapsydrax unicavus is similar to Catapsydrax dissimilis in chamber shape, coiling mode, and thick wall. The bulla is more inflated and has a single aperture (see comments under $C$. dissimilis).

\section{Chiloguembelina spp.}

Plate 2, Fig. 11

Chiloguembelina is a biserial microperforate genus with an asymmetrical aperture. No attempt has been made in this study to distinguish species within the genus using the light microscope because of the poor preservation. Chiloguembelina is usually very abundant in the fine fraction and its last occurrence is very sudden. Some authors have recorded scarce individuals above this level (Subzone P21a), but none was found in this study.

\section{Clavatorella bermudezi (Bolli)}

Plate 2, Figs. 25-26

Hastigerinella bermudezi Bolli, 1957, p. 112, pl. 25, figs. 1a-c.

Clavatorella bermudezi is a Miocene species showing intergradation with Globorotaloides hexagonus at other sites. Some specimens, particularly from toward the top of its range (e.g., Sample 154-925A-4R-2, 75-77 cm) have a large test, extremely elongate and clavate chambers, and also show a tendency toward planispiral coiling (see plate). Such forms are closely homeomorphic with Eocene Clavigerinella eocanica.

\section{Clavigerinella eocanica (Nuttall)}

Plate 2, Figs. 5-7

Hastigerinella eocanica Nuttall, 1928, p. 376, pl. 50, figs. 9-11.

Clavigerinella eocanica is a planispiral form with radially extended, clavate chambers. Blow (1979) and Toumarkine and Luterbacher (1985) both record the extinction of Clavigerinella in the earliest part of the late Eocene. In this study, Clavigerinella was found as high as Sample 154-925A-54R-3, 82-83 cm (Zone P16; a little below the Eocene/Oligocene boundary).

Cribrohantkenina inflata (Howe) Plate 2, Fig. 9

Hantkenina inflata Howe, 1928, p. 14, pl. 14, text-fig. 2.

Multiple areal apertures around the primary aperture distinguish Cribrohantkenina inflata from Hantkenina alabamensis. This species was found in just two samples in Hole 925A. See also Cribrohantkenina lazarii. 
Cribrohantkenina lazarii (Pericoli)

? Plate 2, Fig. 10

Hantkenina lazarii Pericoli, 1958, p. 17, pl. 1, fig. 1-3.

Occasional specimens of Cribrohantkenina in Sample 154-925A-55R-1, $32-33 \mathrm{~cm}$, exhibit a polygonal equatorial profile and were assigned to this species.

$$
\text { Dentoglobigerina altispira s.1. (Cushman and Jarvis) }
$$

Globigerina altispira Cushman and Jarvis, 1936, p. 5, pl. 1, figs. 13-14.

Dentoglobigerina altispira is a distinctive long-ranging form with a high spire and prominent umbilical tooth. Considerable variation was observed in the degree of inflation of the chambers and the tightness of the spiral.

\section{Dentoglobigerina baroemoenensis (LeRoy)}

Globigerina baroemoenensis LeRoy, 1939, p. 263, pl. 6, figs. 1-2, pl. 27, figs. 4,8 .

Dentoglobigerina baroemoenensis possesses four globular and radially compressed chambers in the final whorl. It is a long-ranging form that first appears on the Ceara Rise in the late Oligocene.

Dentoglobigeriana galavisi (Bermudez)

Globigerina galavisi Bermudez, 1961, p. 1183-1184, pl. 4, fig. 3.

Dentoglobigerina galavisi has a morphology similar to Globigerina praebulloides, but the chambers are more closely appressed and it possesses an umbilical tooth. It is the earliest dentoglobigerinid from which a variety of others forms developed. It persists into the lower Miocene in Leg 154 material.

\section{Dentoglobigerina globularis (Bermudez)}

Globoquadrina globularis Bermudez, 1961, p. 311, pl. 13, figs. 4-6.

Dentoglobigerina globularis forms a rough intermediate between Dentoglobigerina galavisi and Dentoglobigerina altispira s.l. It has more chambers and a higher spire than D. galavisi but a more open umbilicus and less closely appressed chambers than D. altispira s.1.

\section{Dentoglobigerina larmeui (Akers)}

Globoquadrina larmeui Akers, 1955, p. 661, pl. 65, figs. 4a-c.

Dentoglobigerina larmeui is an inflated compact dentoglobigerinid with a tight umbilicus and three and a half to four chambers in the final whorl. It is common in the upper Oligocene.

\section{Fohsella birnageae (Blow)}

Globorotalia birnageae Blow, 1959, p. 210, pl. 17, figs. 10a-c

Fohsella birnageae is a small compact fohsellid with five chambers in the final whorl. Although Spezzaferri (1994) records it appearing in the late Oligocene, on the Ceara Rise it was found only in Zone N5/6. Judging from the wall texture and chamber shape, it may be ancestral to Fohsella peripheroron$d a$ although no transitional forms were observed and no overlap in the ranges of the two species was found in this study.

\section{Fohsella fohsi (Cushman and Ellisor)}

Globorotalia fohsi Cushman and Ellisor, 1939, p. 12, pl. 2. figs. 6a-c.

Fohsella fohsi differs from Fohsella "praefohsi" by possessing an imperforate band around the periphery. It shows a greater tendency toward chamber compression and having a more lobate periphery, and tends to be slightly larger.

$$
\text { Fohsella peripheroacuta (Blow and Banner) }
$$
Plate 2, Figs. 22-23
Globorotalia (Turborotalia) peripheroacuta Blow and Banner, 1966, p. 294, pl. 1 , figs. $2 \mathrm{a}-\mathrm{c}$.

Fohsella peripheroacuta has a moderately pinched periphery and forms an intermediate between Fohsella peripheroronda and Fohsella "praefohsi."

$$
\begin{aligned}
& \text { Fohsella peripheroronda (Blow and Banner) } \\
& \text { Plate 2, Fig. } 21
\end{aligned}
$$

Globorotalia (Turborotalia) peripheroronda Blow and Banner, 1966, p. 294, pl. 1, figs. $1 \mathrm{a}-\mathrm{c}$.

Fohsella peripheroronda exhibits a rounded periphery and six chambers in the final whorl. In addition to those fohsellids with a full rounded periphery, we also assigned to $F$. peripheroronda those individuals with a concave ventral chamber face rising at an angle in side view to a relatively raised umbilicus. It is broadly homeomorphic to some members of the Paragloborotalia kugleri group of the earliest Miocene as discussed in Pearson (1995).

\section{Fohsella "praefohsi" Blow and Banner}

Globorotalia (Turborotalia) praefohsi Blow and Banner, 1966, p. 295, pl. 1, figs. $3-4$; pl. 2, figs. 6-7, 10-11.

Blow and Banner (1966) regarded their species as an intermediate between Fohsella peripheroacuta and Fohsella fohsi, and the species has generally been used in that sense by other authors. Bolli and Saunders (1985, p. 213) have questioned this concept on the basis of the holotype morphology and so the name is used here in quotation marks pending further investigation. Rare specimens in Sample 154-925A-3R-2, 75-77 cm, exhibit a lobate periphery in anticipation of the Fohsella lobata morphotype. (Note that Berggren et al. [1995] adopted the view of Bolli and Saunders [1985].)

Globanomalina chapmani (Parr)

Globorotalia chapmani Parr, 1938, p. 87, pl. 3, figs. 8-9.

The holotype of Globanomalina chapmani was illustrated by Haig et al. (1993), removing any doubt that it belongs to the Globigerinacea (cf. Blow, 1979 , p. 1059). It is a small trochospiral form with axially compressed chambers.

\section{Globanomalina pseudomenardii (Bolli)}

Globorotalia pseudomenardii Bolli, 1957, p. 77, pl. 20, figs. 14-17.

Globanomalina pseudomenardii is a distinctive compressed, keeled species. It was found in just two samples at the bottom of Hole 929E, thus establishing the oldest sediments recovered on Leg 154 as belonging to Zone P4.

"Globigerina” anguliofficinalis Blow

“Globigerina” anguliofficinalis Blow, 1969, p. 379, pl. 11, figs. 1-2.

"Globigerina" anguliofficinalis is a morphological intermediate between "Globigerina" ciperoensis and "Globigerina" angulisuturalis. It occurs throughout the range of these taxa.

\section{"Globigerina” angulisuturalis Bolli}

Globigerina angulisuturalis Bolli, 1957, p. 109, pl. 22, figs. 11a-c.

"Globigerina" angulisuturalis is distinguished from "Globigerina" ciperoensis by possessing deeply grooved sutures that separate the flaring chambers. "Globigerina" anguliofficinalis is an intermediate between the two extremes.

\section{"Globigerina” ciperoensis Bolli}

Globigerina ciperoensis Bolli, 1957, p. 109, pl. 22, figs. 10a-b.

"Globigerina" ciperoensis possesses five chambers in the final whorl. The wall texture appears to vary from the typical Globigerina-type in some specimens to being weakly cancellate in others. It is distinguished from similar forms by the morphology of the sutures and the spire height (see comments 
under "Globigerina" fariasi, "Globigerina" anguliofficinalis, and "Globigerina" angulisuturalis). In Leg 154 sediments it ranges as high as the lower part of Zone N5/6 (see also Spezzaferri, 1994).

"Globigerina" fariasi Bermudez

“Globigerina” fariasi Bermudez, 1961, p. 1181, pl. 3, figs. 5a-c.

"Globigerina" fariasi is a high-spired variant of "Globigerina" ciperoensis. It may possess slightly fewer than five whole chambers in the final whorl, probably on account of its higher spire.

\section{Globigerina praebulloides Blow} Plate 2, Fig. 13

Globigerina praebulloides Blow, 1959, p. 180, pl. 8, figs. 47a-c.

Globigerina praebulloides is similar to Globigerina bulloides but is more lobate and has a more elongate equatorial profile. It seems to have been more widespread than G. bulloides and so occurs more frequently in some sections, such as those at Ceara Rise, than does G. bulloides itself. The morphological differences between the two species are very slight (see also comments under Globigerinella obesa). A broad concept is taken to include the forms Globigerina ouachitaensis and Globigerina gnaucki of other authors. Specimens of "Globigerinoides" primordius are indistinguishable except for the single supplementary aperture developed beneath the final chamber of the latter species.

\section{Globigerinatella insueta Cushman and Stainforth} Plate 1, Figs. 13-18

Globigerinatella insueta Cushman and Stainforth, 1945, pl. 13, figs. 7-9.

Globigerinatella insueta is a distinctive microperforate form with a globular test and multiple bullae. In this study, areal apertures are considered essential (see Pearson, 1995, for a full discussion). The number of areal apertures appears to increase up section, but preservation is not sufficiently good for quantifying the effect in Leg 154 material. Areal bullae sometimes cover the apertures. SEM study of a broken specimen (Pl. 1, Figs. 9, 11) reveals an interesting structure within the wall. In this specimen, the final enveloping bulla lies thick and flat on the previous chamber but it encloses interconnecting archlike tunnels.

\section{Globigerinatella sp.}

Plate 1, Figs. 2-12

Globigerinatella sp., Pearson, 1995, p. 47, pl. 2, figs. 7-12.

As discussed in Pearson (1995), forms of Globigerinatella that lack areal apertures are recorded as Globigerinatella sp. These occur below the bottom occurrence of Globigerinatella insueta s. str., but may possess several overlapping bullae. A full intergradation is observed in Leg 154 material between this species and Globigerinita glutinata. Occasional specimens occur throughout most of the range of Globigerinatella insueta.

Globigerinatheka barri Brönnimann

Globigerinatheka barri Brönnimann, 1952, p. 27-28, figs. 3a-c, g, h.

Globigerinathekids similar to Globigerinatheka mexicana but possessing multiple sutural bullae are included in Globigerinatheka barri. However, in Leg 154 material this feature is never as extreme as exhibited by the holotype of the species.

\section{Globigerinatheka index (Finlay)}

Globigerinoides index, Finlay, 1939, p. 125, pl. 14, figs. 85-88.

Globigerinatheka index is a distinctive form with a large, semicircular primary aperture situated above the suture between the first two chambers of the final whorl. The test is more spherical than Globigerinatheka tropicalis.

Globigerinatheka kugleri (Bolli, Loeblich, and Tappan)
Globigerapsis kugleri Bolli, Loeblich, and Tappan, 1957, p. 34, pl. 6, fig. 6.

Globigerinatheka kugleri is a near-spherical form with a bulla-like final chamber covering the umbilicus surrounded by several supplementary apertures.

\section{Globigerinatheka semiinvoluta (Keijzer)}

Globigerionoides semiinvolutus Keijzer, 1945, p. 206, pl. 4, figs. 58a-c.

Globigerinatheka semiinvoluta is distinguished from Globigerinatheka tropicalis by being more inflated and having larger, more circular supplementary sutural apertures.

\section{Globigerinatheka senni (Beckmann)}

Sphaeroidinella senni Beckmann, 1954, p. 394-395, pl. 26, figs. 2-4, text-fig.

Globigerinatheka senni is a small spherical form, usually with three chambers in the final whorl, a thick cortex, and no obvious supplementary apertures.

Globigerinatheka subconglobata (Shutskaya)

Globigerinoides subconglobatus Chalilov var. subconglobata Chalilov in Shutskaya, 1958, pp. 86-87, pl. 1, fig. 4-11.

Globigerinatheka subconglobata is a near-spherical form with small primary and supplementary apertures. Chambers are more closely appressed and less inflated than in Globigerinatheka kugleri.

Globigerinatheka tropicalis (Blow and Banner)

Globigerapsis tropicalis Blow and Banner, 1962, pp. 124-125, pl. 15, figs. D-F.

Globigerinatheka tropicalis is a small globigerinathekid with three chambers in the final whorl, a small arched primary aperture, and supplementary sutural apertures above the sutures between earlier chambers, as in Globigerinoides ruber. The high-spired form Globigerinatheka rubriformis Subbotina is not separated here.

$$
\text { Globigerinella obesa (Bolli) }
$$

Globorotalia obesa Bolli, 1957, p. 119, pl. 29, figs. 2a-c.

As suggested by Kennett and Srinivasan (1983), this species appears to be ancestral to Globigerinella praesiphonifera, from which it is distinguished by having an umbilical-extraumbilical aperture and usually only four chambers in the final whorl. Intermediates between this species and Globigerina praebulloides (which has an umbilical aperture) are found in Zone P22. It is restricted to the upper Oligocene and lower Miocene on the Ceara Rise.

\section{Globigerinella praesiphonifera (Blow)}

Hastigerina siphonifera praesiphonifera Blow, 1969, p. 408, pl. 54, figs. 7-9.

Globigerinella praesiphonifera typically has four and a half chambers in the final whorl and an extraumbilical aperture. The size of the largest specimens varies from sample to sample. In the middle Miocene, some large specimens show a trend toward planispirality in the last few chambers and so anticipate the Globigerinella siphonifera morphospecies.

\section{Globigerinita glutinata (Egger)}

Plate 1, Fig. 1

Globigerina glutinata Egger, 1893, p. 371, pl. 13, figs. 19-21.

Included in Globigerinita glutinata are nonbullate individuals such as are often included in Globigerinita juvenilis. The degree of inflation of the bulla and number of infralaminal apertures vary greatly. The specimen illustrated in Plate 1 shows an inflated chamberlike bulla as in Globigerinatella sp., but 
lacking secondary bullae. Individuals in the latest Oligocene are transitional from the Tenuitellinata group.

\section{Globigerinita uvula (Ehrenberg)}

Pylodexia uvula Ehrenberg, 1861, p. 276.

This species is similar to Globigerinita glutinata, but it has a much higher trochospire. It has a disjunct stratigraphic distribution, suggesting that the morphology may have evolved more than once from $G$. glutinata stock.

\section{Globigerinoides altiaperturus Bolli}

Globigerinoides altiaperturus Bolli, 1957, p. 113, pl. 25, figs. 7a-c.

Globigerinoides altiaperturus is distinguished from Globigerinoides obliquus by having a more umbilically centered primary aperture and a larger secondary aperture.

\section{Globigerinoides bisphericus Todd}

Globigerinoides bisphericus Todd, 1954, p. 681, pl. 1, figs. 1a-c.

Globigerinoides bisphericus is distinguished from Globigerinoides trilobus by having a larger final chamber and smaller umbilicus. It has three apertures around the final chamber, instead of four as in Praeorbulina sicana.

\section{Globigerinoides mitra Todd}

Globigerinoides mitra Todd, 1957, p. 302, pl. 78, figs. 3, 6.

Globigerinoides mitra is a large, high-spired form occasionally encountered in the lower to middle Miocene.

\section{Globigerinoides obliquus Bolli}

Globigerinoides obliquus Bolli, 1957, p. 113, pl. 25, figs. 10a-c.

Globigerinoides obliquus is generally small and possesses an arched, offcenter primary aperture and a supplementary sutural aperture which may be diminutive.

“Globigerinoides" primordius Blow and Banner, 1962

Globigerinoides primordius Blow and Banner, 1962, p. 15, pl. ix, figs. Dd-Ff.

"Globigerinoides" primordius is distinguished from Globigerina praebulloides s.l. by a single supplementary aperture. Individuals are often large, suggesting that the morphospecies may merely represent a late ontogenetic stage of G. praebulloides. The lowest specimen in Hole 925A was found in the lower part of Zone P22.

\section{Globigerinoides ruber s.l. (d'Orbigny)}

Globigerina rubra d'Orbigny, 1839, p. 82, pl. 4, figs. 12-14.

Although some authors refer to lower-middle Miocene specimens of this taxon as Globigerinoides subquadratus, the differences are slight and they are here included in Globigerinoides ruber s.l.

\section{Glopigerinoides sacculifer (Brady)}

Globigerina sacculifer Brady, 1877, p. 164, pl. 9, figs. 7-10; Brady, 1884, p. 604 , pl. 80 , figs. $11-17$; pl. 81 , fig. 2 ; pl. 82 , fig. 4.

Rare variants of Globigerinoides trilobus with a saclike final chamber were separately identified as Globigerinoides sacculifer in this study.

$$
\text { Globigerinoides trilobus s.1. (Reuss) }
$$

Globigerina triloba, Reuss, 1850, p. 374, pl. 47, figs. 11a-e.
A broad concept of this species was taken to include Globigerinoides immaturus of other authors, but not Globigerinoides sacculifer (see discussion above).

$$
\text { Globoquadrina binaensis Koch }
$$

Globoquadrina binaensis Koch, 1935, p. 746, fig. 22a-c.

Globoquadrina binaensis is a distinctive form with a flat, arched, cutaway final chamber. Its stratigraphic range in Hole $925 \mathrm{~A}$ is restricted to three samples in the lower Miocene, possibly because of dissolution. See comments under Globoquadrina sellii.

\section{Globoquadrina dehiscens (Chapman, Parr and Collins)}

Globorotalia dehiscens Chapman, Parr, and Collins, 1934, p. 569, pl. 11, fig. 6.

Globoquadrina dehiscens is a distinctive species with four chambers in the final whorl and an obliquely cut-away final chamber. The first appearance of Globoquadrina dehiscens in Hole 925A is difficult to determine because of dissolution.

\section{Globoquadrina praedehiscens Blow and Banner}

Globoquadrina dehiscens praedehiscens Blow and Banner, 1962, p. 116, pl. 15 , figs. Q-S.

Globoquadrina praedehiscens is similar to Globoquadrina dehiscens but possesses a more rounded test and fewer than four chambers in the final whorl. Premoli Silva and Spezzaferri (1990) record that it has a thicker and more pronounced umbilical tooth.

\section{Globoquadrina pseudovenezuelana Blow and Banner}

Globigerina pseudovenezuelana Blow and Banner, 1962, p. 100, pl. 11, figs. $\mathrm{J}-\mathrm{L}$.

Globoquadrina pseudovenezuelana is slightly smaller and more tightly coiled than Globoquadrina venezuelana. It occurs in the upper Eocene and lower Oligocene of Site 925, whereas G. venezuelana appears in the upper Oligocene. The two morphospecies are probably homeomorphs although the ancestry of both remains uncertain.

\section{Globoquadrina sellii Borsetti}

Globoquadrina sellii Borsetti, 1958, p. 209, pl. 13, figs. 3a-c.

Globoquadrina sellii intergrades with Globoquadrina binaensis but does not exhibit the extreme development of the flat, semicircular apertural face of the final chamber which is so characteristic of the latter taxon. Also, G. sellii generally has three chambers in the final whorl. It is usually subordinate in abundance to Globoquadrina tripartita (which is similar, see below).

\section{Globoquadrina tripartita (Koch)}

Globigerina bulloides (D’Orbigny) var. tripartita Koch, 1926, p. 746, fig. 21.

Globoquadrina tripartita possesses three globular chambers in the final whorl. It has a tighter umbilicus than is characteristic of Globoquadrina praedehiscens. Some authors recognize a separate form that lacks an umbilical tooth as Globoquadrina tapuriensis, but these two taxa have not been separated here. G. tripartita differs from Globoquadrina sellii in lacking any flattening of the apertural face and having less rapidly expanding chambers.

$$
\begin{gathered}
\text { Globoquadrina venezuelana (Hedberg) } \\
\text { Plate 2, Fig. } 14
\end{gathered}
$$

Globigerina venezuelana Hedberg, 1937, p. 681, pl. 92, fig. 7 . (non Globoquadrina venezuelana Kennett and Srinivasan, 1983, pl. 44, figs. 5-7). 
Globoquadrina venezuelana is a large toothless globigerinid with inflated chambers and a deep umbilicus. It is very variable in form. It may be that more regular forms should be separated as Globoquadrina euaperta. See comments under G. pseudovenezuelana).

\section{Globorotalia archeomenardii Bolli}

Plate 2, Fig. 18

Globorotalia archeomenardii Bolli, 1957, p. 119, pl. 28, figs. 11a-c.

See comments under Globorotalia praemenardii and Globorotalia praescitula.

\section{Globorotalia praemenardii Cushman and Stainforth}

Plate 2, Fig. 19

Globorotalia praemenardii Cushman and Stainforth, p. 70, pl. 13, figs. 14a-c.

Globorotalia praemenardii is distinguished from Globorotalia archeomenardii by its larger size, more lobate periphery, and flatter spiral side. There is often a distinctive inflection of the anterior face of the final chamber around the aperture, as in the illustrated specimen. The earliest forms to appear have a fairly convex spiral side, and thus are of intermediate morphology to G. archeomenardii.

\section{Globorotalia praescitula Blow}

Globorotalia scitula (Brady) praescitula Blow, 1959, p. 221, pl. 19, figs. $128 \mathrm{a}-\mathrm{c}$.

Globorotalia praescitula is similar to Globorotalia archeomenardii except in the absence of a fine keel. Its first appearance is as a very rare component of the fine fraction in middle Miocene, which is nevertheless a useful datum.

\section{Globorotaloides carcoselleensis Toumarkine and Bolli}

Globorotaloides carcoselleensis Toumarkine and Bolli, 1975, p. 81, pl. 5, fig. 24.

Globorotaloides carcoselleensis is a small compact form with a final chamber that encroaches on the umbilicus.

\section{Globorotaloides suteri Boll}

Globorotaloides suteri Bolli, 1957, p. 117, pl. 27, figs. 9a-13b.

See comments under Globorotaloides variabilis.

Globorotaloides variabilis Bolli

Globorotaloides variabilis Bolli, 1957, p. 117, pl. 27, figs. 15a-20c.

Globorotalioides variabilis differs from Globorotaloides suteri in having a lower trochospiral, more numerous, and less inflated chambers and a more lobate periphery. The two forms intergrade.

\section{Guembelitria spp.}

Rare triserial microperforates assigned to Guembelitria were found in several samples in Zone P19 at Site 925.

\section{Guembelitrioides lozanoi (Colom)}

Globigerina lozanoi Colom, 1954, p. 149, pl. 2, figs. 1-48.

Guembelitrioides lozanoi is a globular species with five chambers in the final whorl. It differs from Guembelitrioides higginsi by lacking supplementary apertures.

$$
\text { Guembelitrioides higginsi (Bolli) }
$$

“Globigerinoides” higginsi Bolli, 1957, p. 164, pl. 36, figs. 11-13.
Guembelitrioides higginsi is a globular high-spired form with supplementary apertures on the spiral side.

\section{Hantkenina alabamensis Cushman}

Plate 1, Fig. 8 (atypical specimen)

Hantkenina alabamensis Cushman, 1925, p. 3, pl. 1, fig. 1.

Hantkenina alabamensis has a rounded periphery (excepting the tubulospines). Individuals show a great range of variation in the degree of chamber inflation, some approaching the condition of Cribrohantkenina. At Site 929, rare specimens were found in the sample above the last occurrence of the Turborotalia cerroazulensis lineage (i.e., in the base of Zone P18). The illustrated specimen is an atypical form that resembles Hantkenina dumblei of the middle Eocene (cf. Coccioni, 1988)

Hantkenina dumblei Weinzerl and Applin

Hantkenina dumblei Weinzerl and Applin, 1929, p. 402, pl. 43, figs. 5a-b.

Hantkenina dumblei has a distinctive profile, being less stellate than $H$. liebusi and more rapidly expanding than Hantkenina alabamensis. Occasional poorly preserved specimens that may be attributed to this species were found in Sample 154-925A-64R-CC.

\section{Hantkenina liebusi Shokhina}

Hantkenina liebusi Shokhina, 1937, pp. 444-446, pl. 2, figs. 2a-c.

Hantkenina liebusi is distinguished from Hantkenina alabamensis by having a more stellate equatorial profile. In contrast with H. alabamensis, it is very infrequent in Leg 154 material.

\section{Hantkenina mexicana Cushman}

Hantkenina mexicana Cushman, 1925, p. 3, pl. 2, fig. 2.

A few fragmentary specimens of Hantkenina in Sample 154-929E-20R-4, 69-71 cm, are probably referable to Hantkenina mexicana. They are important in establishing the thickness of Zone P10 on the Ceara Rise.

Igorina albeari (Cushman and Bermudez)

Globorotalia albeari Cushman and Bermudez, 1949, p. 33, pl. 6, figs. 1-4. Globorotalia pusilla laevigata Bolli, 1957, p. 78, pl. 20, figs. 5-7.

Globorotalia albeari Cushman and Bermudez, Cifelli and Belford, 1977, p. 102, pl. 1, figs. 4-6 (holotype redescribed).

Igorina albeari is distinguished from all other igorinids by the presence of a fine keel. It is closest to Igorina pusilla and has often been recognized under the name Igorina pusilla laevigata.

\section{Igorina broedermanni (Cushman and Bermudez)}

Globorotalia (Truncorotalia) broedermanni Cushman and Bermudez, 1949, p. 40 , pl. 7 , fig. 24

Globorotalia (Truncorotalia) broedermanni Cushman and Bermudez, Cifelli and Belford, 1977, p. 103, pl. 1, figs. 10-12 (holotype redescribed).

Igorina broedermanni is larger than the other members of the genus and has at least six chambers in the final whorl, a flatter spiral side, and an open umbilicus. Included here are open umbilicate forms described by Blow (1979) as Globorotalia (Acarinina) broedermanni anapetes.

Igorina convexa (Subbotina)

Globorotalia convexa Subbotina, 1953, p. 209, pl. 17, figs. 2-3.

Igorina convexa is a small biconvex igorinid distinguished from Igorina pusilla by having six chambers in the final whorl and from Igorina broedermanni by the smaller size and tight umbilicus.

Morozovella acuta (Toulmin) 
Globorotalia wilcoxensis var. acuta Toulmin, 1941, p. 608, pl. 82, figs. 6-8. Globorotalia velascoensis var. parva Rey, 1955, pl. 12, figs 1a-b.

Morozovella acuta can be thought of as a variant of Morozovella velascoensis possessing the robust, sinistrally coiled test, open umbilicus, and heavily ornamented umbilical shoulders of that taxon, but with fewer chambers per whorl. M. acuta has less than five and a half chambers, compared with more than five and a half in $M$. velascoensis. The $M$. acuta morphospecies is considerably more common than $M$. velascoensis in this material (see also comments under $M$. occlusa).

\section{Morozovella aequa (Cushman and Renz)}

Globorotalia crassata var. aequa Cushman and Renz, 1942, pl. 3, figs 3a-c.

Morozovella aequa possesses four chambers in the final whorl and is almost always dextrally coiled in contrast to the Morozovella velascoensis group. It is distinguished from Morozovella subbotinae, with which it intergrades, by possessing a more delicate keel.

\section{Morozovella aragonensis (Nuttall)}

Plate 2, Fig. 3

Globorotalia aragonensis Nuttall 1930, p. 228, pl. 24, figs. 6-8, 10-11. Globorotalia aragonensis Nuttall, Cifelli and Belford, 1977, p. 102-103, pl.

1, figs. 7-9 (holotype redescribed).

Morozovella aragonensis is distinguished from Morozovella lensiformis only by the number of chambers in the final whorl ( $M$. aragonensis requires at least five). Considerable variation is seen in both the tightness of the umbilicus and the rate of chamber enlargement.

\section{Morozovella densa (Cushman)}

Pulvinulina crassata var. densa Cushman, 1925, p. 301.

Pulvinulina crassata var. densa Cushman, Cifelli, 1972, pp. 157-158, figs. $1 \mathrm{a}-\mathrm{c}$.

non Acarinina densa Berggren, 1977, p. 259

Although this species has highly vaulted chambers like many species of Acarinina, Cifelli's (1972) re-illustration of the holotype shows a weak but definite muricocarina. In spiral view, it is indistinguishable from the much more dorso-ventrally flattened form Morozovella spinulosa, from which it may have evolved.

\section{Morozovella formosa (Bolli)}

Globorotalia formosa formosa Bolli, 1957, p. 76, pl. 18, figs. 1-3.

As described by Bolli (1957), Morozovella formosa differs from Morozovella gracilis by being larger and more robust and in having at least six chambers in the final whorl.

\section{Morozovella gracilis (Bolli)}

Globorotalia formosa gracilis Bolli, 1957, p. 75, pl. 18, figs. 4-6.

As pointed out by Blow (1979), Morozovella gracilis is similar to Morozovella subbotinae, differing mainly in the less tight coiling (often making the umbilicus quite open) and the greater number of chambers per whorl (at least $41 / 2$ ). Like $M$. subbotinae, it tends to be dextrally coiled. See also comments under Morozovella formosa.

\section{Morozovella lehneri}

Globorotalia lehneri Cushman and Jarvis, 1929, p. 17, pl. 3, fig. 16a-c.

Morozovella lehneri is a discoidal form with at least seven radially elongated chambers in the final whorl and a ragged periphery. The sensu stricto form was not found in Ceara Rise sediments but specimens transitional from Morozovella spinulosa were found in Sample 154-929E-11R-2, 70-71 cm.

Morozovella lensiformis (Subbotina)

Globorotalia lensiformis Subbotina, 1953, p. 214, pl. 18, figs. 4a-c, 5a-c.

Morozovella lensiformis is an inflated form distinguished most easily from Morozovella subbotinae in side view, where the chamber sides appear straight or slightly convex in comparison to the concave chambers of the $M$. subbotinae group. It is distinguished from Morozovella aragonensis, with which it fully intergrades, by having fewer chambers per whorl (forms with fewer than five chambers are placed in M. lensiformis).

\section{Morozovella occlusa (Loeblich and Tappan)}

Globorotalia occlusa Loeblich and Tappan, 1957, p. 191, pl 55, fig. 3a-c; pl 64 , fig $3 \mathrm{a}-\mathrm{c}$.

Globorotalia edgari Premoli Silva and Bolli, 1973, p. 526, pl. 7, figs. 10-12, pl. 8 , figs. $1-12$.

Morozovella occlusa differs from Morozovella velascoensis by being smaller and less heavily ornamented and in having a tight umbilicus. Like Morozovella acuta, it tends to have fewer chambers than is typical of $M$. ve lascoensis. The three morphotypes intergrade, with the occlusa morphotype being the most common in this material.

Morozovella spinulosa (Cushman)

Globorotalia spinulosa Cushman, 1927, p. 114, pl. 23, fig. 4a-c.

Morozovella spinulosa is a small, gracile morozovellid with dorso-ventrally flattened chambers and four to five chambers in the final whorl. See comments under Morozovella densa.

\section{Morozovella subbotinae (Morozova)}

Globorotalia subbotinae Morozova, 1939, p. 80, pl. 2, figs. 16-17.

Morozovella subbotinae is distinguished from Morozovella aequa by possessing a more acute periphery and a more distinct keel, and from Morozovella gracilis by having only four chambers in the final whorl.

\section{Morozovella velascoensis (Cushman)}

Plate 2, Figs. 1-2

Pulvinulina velascoensis Cushman, 1925, p. 19, pl. 3, figs. 5a-c.

Morozovella velascoensis is a large, robust form with a highly vaulted ventral side and an open umbilicus. Sensu stricto forms possess seven chambers in the final whorl but are very rare in this material. Forms with five to six chambers are more common. A full intergradation to Morozovella occlusa is observed. Both forms are almost exclusively sinistrally coiled in this material.

\section{Orbulina universa d'Orbigny}

Plate 2, Fig. 10

Orbulina universa d'Orbigny, 1839, p. 2, pl. 1, fig. 1.

The illustrated specimen is of the suturalis type from the bottom of its stratigraphic range. It is distinguished from Praeorbulina circularis by possessing areal apertures. Orbulina suturalis is not distinguished from Orbulina universa in this study because recognition of the areal apertures is difficult in poorly preserved material and is dissolution dependent.

Orbulinoides beckmanni (Saito) Plate 2, Fig. 4

Porticulasphaera beckmanni Saito, 1962, pp. 221-222, pl. 34, figs. 1a-2. 
Orbulinoides beckmanni is a large spherical species related to the globigerinathekids in which the large final chamber is surrounded by many sutural apertures.

\section{Paragloborotalia continuosa (Blow)}

Globorotalia opima continuosa Blow, 1959, p. 218, pl. 19, figs. 125a-c.

Small compact unkeeled globorotaliids are a minor constituent of most lower Miocene assemblages and are lumped under the name Paragloborotalia continuosa, although it is possible that several similar taxa have been included together.

\section{Paragloborotalia kugleri (Bolli)}

Plate 2, Fig. 17

Globorotalia kugleri Bolli, 1957, p. 118, pl. 28, figs. 5-6.

The taxonomic concept of Paragloborotalia kugleri has been debated by various authors as summarized in Pearson (1995).

\section{Paragloborotalia mayeri (Cushman and Ellisor)} Plate 2, Fig. 20

Globorotalia mayeri Cushman and Ellisor, p. 11, pl. 2, figs. 4a-c.

A broad concept of Paragloborotalia mayeri is taken to include the Paragloborotalia siakensis of some authors. Dramatic fluctuations in the abundance of this species occur in the upper Oligocene (Zone P22). When it is rare, populations are dominated by small individuals.

\section{Paragloborotalia nana (Bolli)}

Globorotalia opima nana Bolli, 1957, p. 118, pl. 28, figs. 3a-c.

See comments under Paragloborotalia opima.

$$
\text { Paragloborotalia opima (Bolli) }
$$

Globorotalia opima opima Bolli, 1957, p. 117, pl. 28, figs. 1-2.

Bolli and Saunders (1985) distinguished Paragloborotalia opima from Paragloborotalia nana by size alone. Spezzaferri (1994) draws attention to the slightly more lobate profile, slightly higher arched aperture, and larger final chamber. In this study, the unambiguous size criterion is retained for distinguishing the two morphospecies pending further investigation.

\section{Paragloborotalia pseudokugleri (Blow)}

Plate 2, Fig. 16

Globorotalia (Turborotalia) pseudokugleri Blow, 1969, p. 391, pl. 10, figs. $4-6$, pl. 39, figs. 5-6.

Paragloborotalia pseudokugleri is distinguished from Paragloborotalia kugleri by its more globular chambers and straighter intercameral sutures. Although it is often of smaller size than typical P. kugleri, some samples contain large specimens with seven chambers in the final whorl, particularly in the earlier part of its range.

\section{Planorotalites pseudoscitula (Glaessner)}

Globorotalia pseudoscitula Glaessner, 1937, p. 32, figs. 3a-c.

Planorotalites pseudoscitula is a small keeled species found mainly in the $<150-\mu \mathrm{m}$ size fraction. The full stratigraphic range is difficult to determine because of strong dissolution in the middle Eocene.

\section{Praeorbulina circularis (Blow)}

Globigerinoides glomerosa circularis Blow, 1956, p. 65, text-fig. 2, nos. 3-4.
Praeorbulina circularis is a near-spherical form with small circular sutural apertures but lacking areal apertures as in Orbulina.

Praeorbulina curva (Blow)

Globigerinoides glomerosa curva Blow, 1956, p. 64, text-fig. 1, nos. 9-14.

Praeorbulina curva has more apertures around the final chamber than Praeorbulina sicana, but fewer than Praeorbulina glomerosa.

\section{Praeorbulina glomerosa (Blow)}

Globigerinoides glomerosa glomerosa Blow, 1956, p. 64, text-fig. 1, nos. 1519; text-fig. 2, nos. 1-2.

Praeorbulina glomerosa has numerous slit-like supplementary apertures forming an almost continuous groove around the base of the final chamber.

$$
\text { Praeorbulina sicana (De Stefani) }
$$

Globigerinoides sicanus De Stefani, 1950, p. 9, fig. 6.

According to Jenkins et al. (1981), Praeorbulina sicana is distinguished from Globigerinoides bisphericus by having four apertures around the base of the final chamber instead of three. We have attempted to follow this distinction, even though it is a difficult one to make. The overriding importance of this question lies in the fact that it is necessary for the recognition of the base of Zone N8. Our concern lies in the ambiguity of counting apertures along the sutural groove of these forms. SEM studies show that the tiny apertures are often not very well marked or separated. Furthermore, in the chalky Leg 154 material, the pores are often clogged despite careful cleaning. We have assigned specimens to $P$. sicana only when it is obvious that four apertures are present, but we expect that a very careful SEM study of better material would place the first appearance of $P$. sicana at a lower level. See also comments under P. curva.

\section{Protentella sp.}

Occasional broken specimens attributable to Protentella were found in the Oligocene and lower Miocene of Sites 925, 926, and 929. Because of poor preservation, no attempt was made to assign them to species (cf. the taxonomy of Spezzaferri, 1994).

Pseudohastigerina micra (Cole)

Nonion micrus Cole, 1927, p. 22, pl. 5, fig. 2.

The larger size, more rapidly expanding chambers, and strongly recurved sutures distinguish this form from Pseudohastigerina naguewichiensis. The first appearance of Pseudohastigerina micra in Site 929 is in Sample 154929E-19R-6, 70-72 cm, although samples immediately below are strongly af fected by dissolution. Pseudohastigerina micra persists into the upper Eocene (Zone P18) where it co-occurs with $P$. naguewichiensis, thus closing the disjunct range of Pseudohastigerina noted by Blow (1979). No intermediates between these two taxa were found, however.

\section{Pseudohastigerina naguewichiensis Mjatliuk}

Globigerinella naguewichiensis Mjatliuk, 1950, p. 281, plate IV, fig. 4a, b.

This small pseudohastigerinid persists well into the lower Oligocene, its final extinction being visible only in the fine $(<150 \mu \mathrm{m})$ fraction. Blow (1979) used the slightly more appressed chambers and larger, deeper pore pits of some individuals in distinguishing Pseudohastigerina barbadoensis. Preservation in Leg 154 material is not sufficient to assess whether that is a genuinely separate form (see also Toumarkine and Luterbacher, 1985)

Pseudohastigerina wilcoxensis Cushman and Ponton

Nonion wilcoxensis Cushman and Ponton, 1932, p. 64, pl. 8, figs. 11a-b. 
Pseudohastigerina wilcoxensis is a planispiral form distinguished from Pseudohastigerina micra by the greater degree of chamber inflation. Several specimens were found, all in Sample 154-929E-27R-2, 72-74 cm (Zone P6).

\section{Sphaeroidinellopsis seminulina (Schwager)}

Globigerina seminulina Schwager, 1886, p. 256, pl. 7, fig. 112.

Sphaeroidinellopsis seminulina is a frequently encountered form in the middle Miocene of the Ceara Rise.

\section{Streptochilus spp.}

Occasional specimens of this biserial genus were found in the lower Miocene (Zone N5/6).

Subbotina angiporoides (Hornibrook)

Globigerina angiporoides Hornibrook, 1965, pp. 835-838, fig. 1, nos. a-i.

Subbotina angiporoides has a low slit-like aperture and prominent apertural lip. It differs from Subbotina linaperta in having more globular chambers. It ranges as high as the bottom part of Zone N22 at Site 925.

Subbotina bolivariana Petters

Globigerina wilsoni bolivariana Petters, 1954, p. 39, pl. 8, figs. 9a-c.

This distinctive subbotinid has involute chambers and a tendency toward planispiral coiling in the final whorl reminiscent of Globigerinella siphonifera. It was found as high as Zone P12 in Sites 925 and 929.

Subbotina eocaena Guembel

Globigerina eocana Guembel, 1868, p. 662, pl. 2, figs. 109a-b.

This large subbotinid has a thin apertural lip and more inflated chambers than Globoquadrina pseudovenezuelana. It first appears in the middle Eocene on the Ceara Rise.

\section{Subbotina frontosa (Subbotina)}

Globigerina frontosa Subbotina, 1953, p. 84, pl. 12, figs. 3-7.

Subbotina frontosa has a distinctive high arched aperture and flattened spiral side, and a predominance for dextral coiling.

\section{Subbotina gortanii (Borsetti)}

Catapsydrax gortanii Borsetti, 1959, p. 205, pl. 1, figs. 1a-d.

See comments under Subbotina praeturritilina.

\section{Subbotina inaequispira (Subbotina)}

Globigerina inaequispira Subbotina, 1953, p. 69, pl. 6, figs. 1-4.

Subbotina inaequispira is a generalized form with loosely appressed, globular chambers.

\section{Subbotina linaperta (Finlay)}

Globigerina linaperta Finlay, 1939, p. 125, pl. 13, figs. 54-57.

Subbotina linaperta has three chambers in the final whorl and radially compressed chambers. It ranges into the uppermost Eocene on the Ceara Rise.

Subbotina praeturritilina (Blow and Banner)

Globigerina turritilina praeturritilina Blow and Banner, 1962, p. 99, pl. XII, figs. A-C.
Subbotina praeturritilinais a large subbotinid similar to Subbotina gortanii but has a lower spire and lacks the distinctive bulla-like chamberlet found in many adult specimens of that taxon. Rare specimens in Sample 154-925A17R-3, 74-77 cm, may be reworked.

Subbotina velascoensis (Cushman)

Globigerina velascoensis Cushman, 1925, p. 19, pl. 3, fig. 6.

Subbotinids with radially compressed chambers are commonly found in Paleocene sediments and are usually attributed to Subbotina velascoensis. This usage is continued in this contribution although Blow (1979) alluded to the crushed nature of the holotype, which accounts for the misleading appearance of low-spired evolute coiling in the illustrations given by Cushman.

\section{Tenuitella clemenciae (Bermudez)}

Turborotalia clemenciae Bermudez, 1961, p. 1321, pl. 17, figs. 10a-b.

Small microperforate individuals with five rapidly expanding chambers were included in this taxon. At Site 925, the morphospecies occurs with Tenuitella gemma and Tenuitella munda through the Oligocene and lower Miocene but persists into the middle Miocene.

Tenuitella gemma Jenkins

Tenuitella gemma Jenkins, 1966, p. 1115, pl. 11, nos. 97-103.

This small species has five or more globular chambers in the final whorl and an umbilical-extraumbilical aperture. No attempt was made to separate the form Tenuitella neoclemenciae $\mathrm{Li}$, which may be a synonym.

\section{Tenuitella munda Jenkins}

Tenuitella munda Jenkins, 1966, p. 1121, pl. 13, nos. 152-156.

Tenuitella munda is a microperforate species with four chambers in the final whorl. The dissolved and recrystallized nature of late Eocene and Oligocene samples make this small generalized taxon difficult to identify with confidence. Individuals in the upper Eocene may be referable to another taxon, such as Tenuitella insolita.

Tenuitellinata angustiumbilicata (Bolli)

Plate 2, Fig. 15

Globigerina ciperoensis angustiumbilicata Bolli, 1957, p. 109, pl. 22, figs. $12-13$.

Tenuitellinata angustiumbilicata is a microperforate species similar to "Globigerina" ciperoensis and is distinguished from Tenuitella gemma by its larger size and umbilical aperture. Individuals with an umbilical bulla were occasionally found but were not separated.

$$
\text { Turborotalia ampliapertura (Bolli) }
$$

Globigerina ampliapertura Bolli, 1957, p. 108, pl. 22, figs. 5a-7b.

Turborotalia ampliapertura is distinguished from Turborotalia increbescens by its more umbilical aperture and Turborotalia pomeroli by its higher spire and more strongly arched aperture.

\section{Turborotalia cerroazulensis (Cole)}

Globigerina cerroazulensis Cole, 1928, p. 217, pl. 32, figs. 11-13.

Turborotalia cerroazulensis has an acute periphery through most of the final whorl, which distinguishes it from Turborotalia pomeroli. However, the periphery is less acute than in Turborotalia cocoaensis. The lost holotype of Globorotalia centralis Cushman and Bermudez appears to be of similar morphology. 


\section{Turborotalia cocoaensis (Cushman)}

Globorotalia cocoaensis Cushman, 1928, p. 75, pl. 10, figs. 3a-c.

Turborotalia cocoaensis has a more acute periphery than Turborotalia cerroazulensis but intermediates abound. The periphery on the earlier chambers of the final whorl may be sharp and angular, but there is no keel.

\section{Turborotalia cunialensis (Toumarkine and Bolli)}

Globorotalia cerroazulensis cunialensis Toumarkine and Bolli, 1970, p. 144, pl. 1, fig. 37.

Turborotalia cunialensis is the final compressed, keeled morphospecies belonging to the Turborotalia cerroazulensis lineage. In Hole 925A, it was found in just two samples, above the last occurrence of Cribrohantkenina. These occurrences are questionable because our samples at this level contain many crushed tests.

\section{Turborotalia increbescens (Bandy)}

Globigerina increbescens Bandy, 1949, p. 120, pl 23, figs. 3a-c.

Turborotalia increbescens has a low trochospiral and a rounded spiral side. It differs from Turborotalia pomeroli by its smaller size and by lacking the high ovoid final chamber typical of that species and other members of the Turborotalia cerroazulensis lineage. Juveniles of that lineage are difficult to separate from $T$. increbescens, although the latter clearly outlives $T$. cerroazulensis. Turborotalia increbescens may be an intermediate between $T$. pomeroli and Turborotalia ampliapertura.

Turborotalia pomeroli (Toumarkine and Bolli)

Globorotalia cerroazulensis pomeroli Toumarkine and Bolli, 1970, p. 140, pl. 1 , fig. 13 .

This is the most primitive member of the Turborotalia cerroazulensis lineage. As discussed by Toumarkine and Luterbacher (1985), the neotype of Globorotalia centralis selected by Cifelli and Belford (1977) is probably a synonym of Turborotalia pomeroli. Turborotalia pomeroli differs from $T$. cerroazulensis by being more globular and less flattened on the spiral side.

Zeaglobigerina connecta (Jenkins)

Globigerina connecta Jenkins, 1964, p. 72, pl. 18, figs. 545-547.

Zeaglobigerina connecta is a distinctive form related to Zeaglobigerina woodi but possesses three chambers in the final whorl and a strongly cancellate wall texture. It is restricted to the lower Miocene Zone N4 in Ceara Rise sediments.

Zeaglobigerina woodi (Jenkins)

Globigerina woodi Jenkins, 1960, p. 352, pl. 2, figs. 15-26.

Zeaglobigerina woodi possesses four chambers in the final whorl and a wide arched aperture. No attempt has been made here to separate the related forms Zeaglobigerina brazieri and Zeaglobigerina druryi of other authors.

\section{ACKNOWLEDGMENTS}

We would like to thank Tim Bralower, Bill Berggren, and Brian Huber for various comments and suggestions, and Hisato Yasuda, Jan Backman, and Isabella Raffi for good company in the paleontology lab during an enjoyable cruise. PNP was supported by a Royal Society University Research Fellowship.

\section{REFERENCES}

Berggren, W.A., 1982. Blow, blow, blow your horn. 3rd N. Am. Paleontol. Conv. Proc., 1:47-50.
Berggren, W.A., Kent, D.V., and Flynn, J.J., 1985a. Jurassic to Paleogene, Part 2. Paleogene geochronology and chronostratigraphy. In Snelling, N.J. (Ed.), The Chronology of the Geological Record. Geol. Soc. London Mem., 10:141-195.

Berggren, W.A., Kent, D.V., Swisher, C.C., III, and Aubry, M.-P., 1995. A revised Cenozoic geochronology and chronostratigraphy. In Berggren, W.A., Kent, D.V., and Hardenbol, J. (Eds.), Geochronology, Time Scales and Global Stratigraphic Correlation: A Unified Temporal Framework for an Historical Geology. Spec. Publ.-Soc. Econ. Paleontol. Mineral., 54:129-212.

Berggren, W.A., Kent, D.V., and Van Couvering, J.A., 1985b. The Neogene, Part 2. Neogene geochronology and chronostratigraphy. In Snelling, N.J. (Ed.), The Chronology of the Geological Record. Geol. Soc. London Mem., 10:211-260.

Berggren, W.A., and Miller, K.G., 1988. Paleogene tropical planktonic foraminiferal biostratigraphy and magnetobiochronology. Micropaleontology, 34:362-380.

Blow, W.H., 1969. Late middle Eocene to Recent planktonic foraminiferal biostratigraphy. In Brönnimann, P., and Renz, H.H. (Eds.), Proc. First Int. Conf. Planktonic Microfossils, Geneva, 1967: Leiden (E.J. Brill), $1: 199-422$.

, 1979. The Cainozoic Globigerinida: Leiden (E.J. Brill).

Blow, W.H., and Banner, F.T., 1966. The morphology, taxonomy and biostratigraphy of Globorotalia barisanensis LeRoy, Globorotalia fohsi Cushman and Ellisor, and related taxa. Micropaleontology, 12:286-302.

Boersma, A., 1977. Cenozoic planktonic foraminifera, DSDP Leg 39 (South Atlantic). In Perch-Nielsen, K., Supko, P.R., et al., Init. Repts. DSDP, 39: Washington (U.S. Govt. Printing Office), 567-590.

Bolli, H.M., 1957. Planktonic foraminifera from the Oligocene-Miocene Cipero and Lengua formations of Trinidad, B.W.I. In Loeblich, A.R., Jr., Tappan, H., Beckmann, J.P., Bolli, H.M., Gallitelli, E.M., and Troelsen, J.C. (Eds.), Studies in Foraminifera. Bull.-U.S. Nat. Mus., 215:97-123.

Bolli, H.M., and Saunders, J.B., 1985. Oligocene to Holocene low latitude planktonic foraminifera. In Bolli, H.M., Saunders, J.B., and PerchNielsen, K. (Eds.), Plankton Stratigraphy: Cambridge (Cambridge Univ. Press), 155-262.

Cande, S.C., and Kent, D.V., 1992. A new geomagnetic polarity time scale for the Late Cretaceous and Cenozoic. J. Geophys. Res., 97:1391713951.

, 1995. Revised calibration of the geomagnetic polarity timescale for the Late Cretaceous and Cenozoic. J. Geophys. Res., 100:6093-6095.

Chaisson, W.P., and Leckie, R.M., 1993. High-resolution Neogene planktonic foraminifer biostratigraphy of Site 806, Ontong Java Plateau (western equatorial Pacific). In Berger, W.H., Kroenke, L.W., Mayer, L.A., et al., Proc. ODP, Sci. Results, 130: College Station, TX (Ocean Drilling Program), 137-178.

Cifelli, R., 1972. The holotypes of Pulvinulina crassata var. densa Cushman and Globigerina spinuloinflata Bandy. J. Foraminiferal Res., 2:157-159.

Cifelli, R., and Belford, D.J., 1977. The types of several species of Tertiary planktonic foraminifera in the collection of the U.S. National Museum of Natural History. J. Foraminiferal Res., 7:100-105.

Coccioni, R., 1988. The genera Hantkenina and Cribrohantkenina (Foraminifera) in the Massignano section (Ancona, Italy). In Premoli Silva, I., Coccioni, R., and Montanari, A. (Eds.), The Eocene-Oligocene Boundary in the Marche-Umbria Basin (Italy). Int. Subcomm. Paleogr. Strat., Eocene/Oligocene Meeting, Spec. Publ., 2:81-96.

Curry, W.B., Shackleton, N.J., Richter, C., et al., 1995. Proc. ODP, Init. Repts., 154: College Station, TX (Ocean Drilling Program).

Fordham, B.G., 1986. Miocene-Pleistocene planktic foraminifers from DSDP Sites 208 and 77, and phylogeny and classification of Cenozoic species. Evol. Monogr., 6:1-200.

Haig, D.W., Griffin, B.J., and Ujetz, B.F., 1993. Redescription of type specimens of Globorotalia chapmani Parr from the upper Paleocene, Western Australia. J. Foraminiferal Res., 23:275-280.

Hilgen, F.J., 1991. Extension of the astronomically calibrated (polarity) time scale to the Miocene/Pliocene boundary. Earth Planet. Sci. Lett., 107:349-368.

Jenkins, D.G., Saunders, J.B., and Cifelli, R., 1981. The relationship of Globigerinoides bisphericus Todd 1954 to Praeorbulina sicana (de Stefani) 1952. J. Foraminiferal Res., 11:262-267.

Kelly, D.C., Bralower, T.J., Zachos, J.C., and Premoli Silva, I., 1995. Biotic responses in the tropical pelagic realm to the late Paleocene thermal maximum at ODP Site 865. 5th Int. Conf. on Palaeoceanography, Programs and Abstracts, 194. 
Kennett, J.P., and Srinivasan, M.S., 1983. Neogene Planktonic Foraminifera: A Phylogenetic Atlas: Stroudsburg, PA (Hutchinson Ross).

Loeblich, A.R., and Tappan, H., 1957. Planktonic foraminifera of Paleocene and early Eocene age from the Gulf Coast and Atlantic coastal plains. Bull. U.S. Nat. Mus., 215:173-197.

Melillo, A.J., 1988. Neogene planktonic foraminifer biostratigraphy, ODP Leg 101, Bahamas. In Austin, J.A., Jr., Schlager, W., et al., Proc. ODP, Sci. Results, 101: College Station, TX (Ocean Drilling Program), 3-45.

Norris, R.D., Corfield, R.M., and Cartlidge, J.E., 1993. Evolution of depth ecology in the planktic foraminifera lineage Globorotalia (Fohsella). Geology, 21:975-978.

Pearson, P.N., 1992. Survivorship analysis of fossil taxa when extinction rates vary: the Paleogene planktonic foraminifera. Paleobiology, 18:115131 .

, 1993. A lineage phylogeny for the Paleogene planktonic foraminifera. Micropaleontology, 39:193-232.

, 1995. Planktonic foraminifer biostratigraphy and the development of pelagic caps on guyots in the Marshall Islands Group. In Haggerty, J., Premoli Silva, I., Rack, F., and McNutt, M.K. (Eds.), Proc. ODP, Sci. Results, 144: College Station, TX (Ocean Drilling Program), 21-59.

Pearson, P.N., Shackleton, N.J., and Hall, M.A., 1993. Stable isotope paleoecology of middle Eocene planktonic foraminifera and integrated isotope stratigraphy, DSDP Site 523, South Atlantic. J. Foraminiferal Res., 23:123-140.

Postuma, J.A., 1971. Manual of Planktonic Foraminifera: Amsterdam (Elsevier).

Premoli Silva, I., and Spezzaferri, S., 1990. Paleogene planktonic foraminifer biostratigraphy and paleoenvironmental remarks on Paleogene sediments from Indian Ocean sites, Leg 115. In Duncan, R.A., Backman, J., Peterson, L.C., et al., Proc. ODP, Sci. Results, 115: College Station, TX (Ocean Drilling Program), 277-314.
Proto Decima, F., and Bolli, H.M., 1970. Evolution and variability of Orbulinoides beckmanni (Saito). Eclogae Geol. Helv., 63: 883-905.

Shackleton, N.J., Berger, A., and Peltier, W.A., 1990. An alternative astronomical calibration of the lower Pleistocene timescale based on ODP Site 677. Trans. R. Soc. Edinburgh: Earth Sci., 81:251-261.

Shackleton, N.J., Crowhurst, S., Hagelberg, T., Pisias, N.G., and Schneider, D.A., 1995. A new late Neogene time scale: application to Leg 138 sites. In Pisias, N.G., Mayer, L.A., Janecek, T.R., Palmer-Julson, A., and van Andel, T.H. (Eds.), Proc. ODP, Sci. Results, 138: College Station, TX (Ocean Drilling Program), 73-101.

Spezzaferri, S., 1994. Planktonic foraminiferal biostratigraphy and taxonomy of the Oligocene and lower Miocene in the oceanic record: an overview. Palaeontographica Ital., 81:1-187.

Subbotina, N.N., 1953. Iskopaemye foraminifery SSSR: Globigerinidae, Hantkeninidae, i Globorotaliidae. Tr. Vses. Nauchno-Issled. Geologo-razved. Neft. Inst. (VNIGRI), 76.

Toumarkine, M., and Luterbacher, H., 1985. Paleocene and Eocene planktic foraminifera. In Bolli, H.M., Saunders, J.B., and Perch-Nielsen, K. (Eds.), Plankton Stratigraphy: Cambridge (Cambridge Univ. Press), 87154.

Wright, J.D., and Miller, K.G., 1992. Miocene stable isotope stratigraphy, Site 747, Kerguelen Plateau. In Wise, S.W., Jr., Schlich, R., et al., Proc. ODP, Sci. Results, 120: College Station, TX (Ocean Drilling Program), $855-866$

Date of initial receipt: 7 December 1995

Date of acceptance: 22 April 1996

Ms 154SR-106 


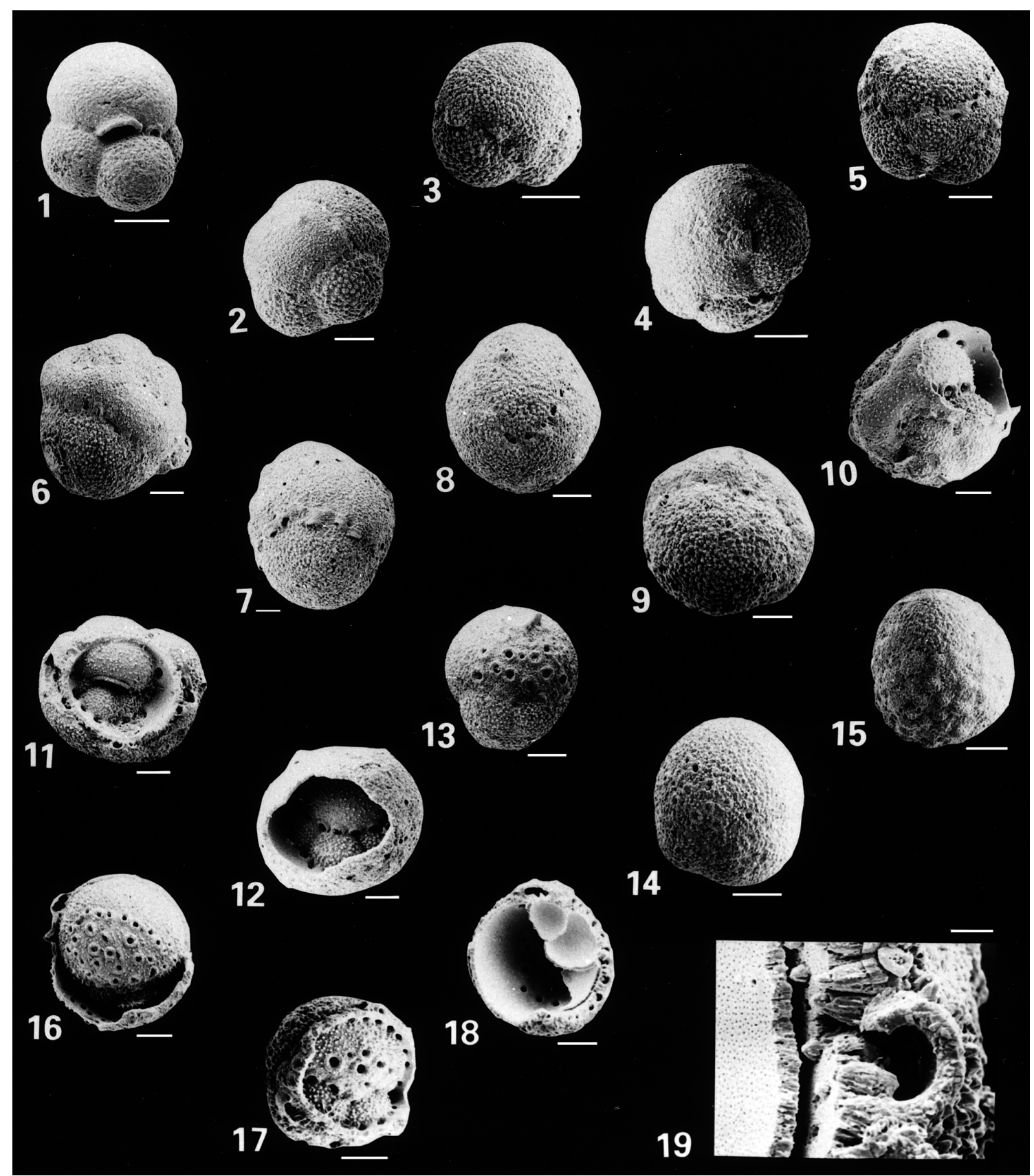

Plate 1. Globigerinita-Globigerinatella transition. 1. Globigerinita glutinata, showing swollen chamberlike bulla with two apertures, Sample 154-925A-13R-2, $75-77 \mathrm{~cm}$, Zone N5/6 (an unusually large specimen, possibly a juvenile of the Globigerinatella lineage). 2. Globigerinatella sp., Sample 154-926B-35X-2, 70$72 \mathrm{~cm}$, Zone N7. 3. Globigerinatella sp., Sample 154-926A-33H-4, 70-72 cm, Zone N5/6. 4. Globigerinatella sp., Sample 154-926B-35X-2, 70-72 cm, Zone N5/6. 5. Globigerinatella sp., Sample 154-926B-35X-2, 70-72 cm, Zone N5/6. 6. Globigerinatella sp., Sample 154-926B-35X-2, 70-72 cm, Zone N5/6. 7. Globigerinatella sp., Sample 154-926B-35X-2, 70-72 cm, Zone N5/6. 8. Globigerinatella sp., Sample 154-926A-33H-4, 70-72 cm, Zone N5/6. 9. Globigerinatella sp., Sample 154-926A-33H-4, 70-72 cm, Zone N5/6. 10. Globigerinatella sp., Sample 154-926A-33H-4, 70-72 cm, Zone N5/6. 11. Globigerinatella sp., Sample 154-926B-35X-2, 70-72 cm, Zone N5/6. 12. Globigerinatella insueta, Sample 154-926A-33H-4, 70-72 cm, Zone N5/6. 13. Globigerinatella insueta, Sample 154-925C-35X-4, 65-67 cm, Zone N8. 14. Globigerinatella insueta, Sample 154-926B-34X-2, 70-72 cm, Zone N8. 15. Globigerinatella insueta, showing small bullae covering areal apertures, Sample 154-925C-35X-4, 65-67 cm, Zone N8. 16. Globigerinatella insueta, broken specimen showing clustering of areal apertures, Sample 154-925C-35X-4, 65-67 cm, Zone N8. 17. Globigerinatella insueta, broken specimen, Sample 154-926B-34X-2, 70-72 cm, Zone N8. 18. Globigerinatella insueta., broken specimen, Sample 154-926A-32H-4, 70-72 cm, Zone N8. 19. Globigerinatella insueta, same specimen as Figure 9, showing arched canal-like structures within the flat-lying bulla-wall. Scale bars $=100 \mu \mathrm{m}$, except Figure $19=10 \mu \mathrm{m}$. 


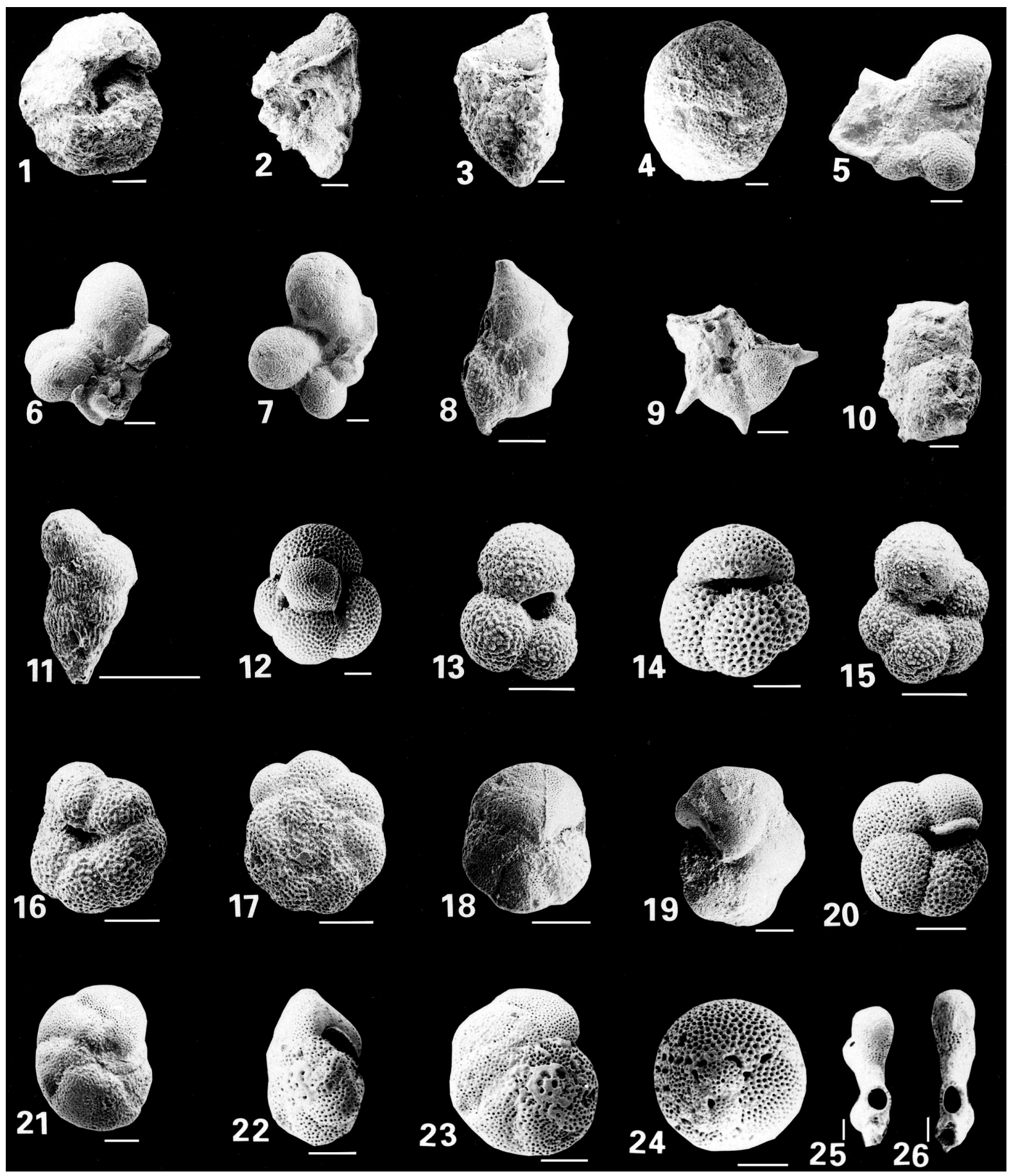

Plate 2. Various planktonic foraminifers. 1. Morozovella velascoensis, Sample 154-929E-35R-CC, Zone P5. 2. Morozovella velascoensis, Sample 154-929E35R-CC, Zone P5 (side view). 3. Morozovella aragonensis, Sample 154-929E-15R-4, 68-70 cm, Zone P12. 4. Orbulinoides beckmanni, Sample 154-925A68R-CC, Zone P13. 5. Clavigerinella eocanica, Sample 154-929E-16R-6, 70-72 cm, Zone P11. 6. Clavigerinella eocanica, showing irregular chamber arrangement, Sample 154-925A-54R-3, 82-83 cm, Zone P16. 7. Clavigerinella eocanica, Sample 154-925A-56R-2, 41-43 cm, Zone P15. 8. Hantkenina alabamensis, specimen reminiscent of Hantkenina dumblei, Sample 154-929A-52X-6, 45-47 cm, Zone P18. 9. Cribrohantkenina inflata, Sample 154-925A-54R-3, 82-83 $\mathrm{cm}$, Zone P16. 10. Cribrohantkenina lazarii?, broken specimen, Sample 154-925A-54R-CC, Zone P16. 11. Chiloguembelina cubensis, Sample 154-925A-33R1, 70-73 cm, Zone P22. 12. Catapsydrax dissimilis, Sample 154-926B-50X-1, 114-116 cm, Zone N4. 13. Globigerina praebulloides, Sample 154-928B-41X2, 70-72 cm, Zone P22. 14. Globoquadrina venezuelana, (c.f. euaperta), Sample 154-929A-36X-2, 70-72 cm, Zone P22. 15. Tenuitellinata angustiumbilicata, Sample 154-928B-41X-2, 70-72 cm, Zone P22. 16. Paragloborotalia pseudokugleri, Sample 154-926B-52X-6, 65-67 cm, Zone P22. 17. Paragloborotalia kugleri, Sample 154-925A-22R-7, 64-66 cm, Zone N4. 18. Globorotalia archeomenardii, Sample 154-926B-31X-2, 73-75 cm, Zone N10. 19. Globorotalia praemenardii, Sample 154-925A-4R-4, 75-77 cm, Zone N9. 20. Paragloborotalia mayeri, Sample 154-929A-36X-2, 70-72 cm, Zone N9. 21. Fohsella peripheroronda, Sample 154-929A-24X-6, 70-72 cm, Zone N10. 22. Fohsella peripheroacuta, showing acute periphery, Sample 154-929A-24X-6, 70-72 cm, Zone N10. 23. Fohsella peripheroacuta, showing distinctive late-stage calcification in proloculus area, Sample 154-929A-24X-6, 70-72 cm, Zone N10. 24. Orbulina universa (cf. suturalis type), Sample 154-929A-24X-6, 70-72 cm, Zone N10. 25. Clavatorella bermudezi, showing near-planispiral coiling, Sample 154-925C$35 X-4,65-67 \mathrm{~cm}$, Zone N8. 26. Clavatorella bermudezi, showing near-planispiral coiling, Sample 154-926B-31X-4, 73-75 cm, Zone N9. Scale bars $=100 \mu \mathrm{m}$. 